\title{
AVALIAÇÃO E ANÁLISE DAS DISTÂNCIAS BIOLÓGICAS DO PERIODONTO MEDIANTE NOVA METODOLOGIA
}

\section{JOSÉ ALFREDO GOMES DE MENDONÇA}

Tese apresentada à Faculdade de Odontologia de Bauru, da Universidade de São Paulo, como parte dos requisitos para obtenção do título de Doutor em Odontologia, área de Periodontia.

(Edição Revisada) 


\section{AVALIAÇÃO E ANÁLISE DAS DISTÂNCIAS BIOLÓGICAS DO PERIODONTO MEDIANTE NOVA METODOLOGIA}

JOSÉ ALFREDO GOMES DE MENDONÇA

Tese apresentada à Faculdade de Odontologia de Bauru, da Universidade de São Paulo, como parte dos requisitos para obtenção do título de Doutor em Odontologia, área de Periodontia.

Orientador: Prof. Dr. Euloir Passanezi 


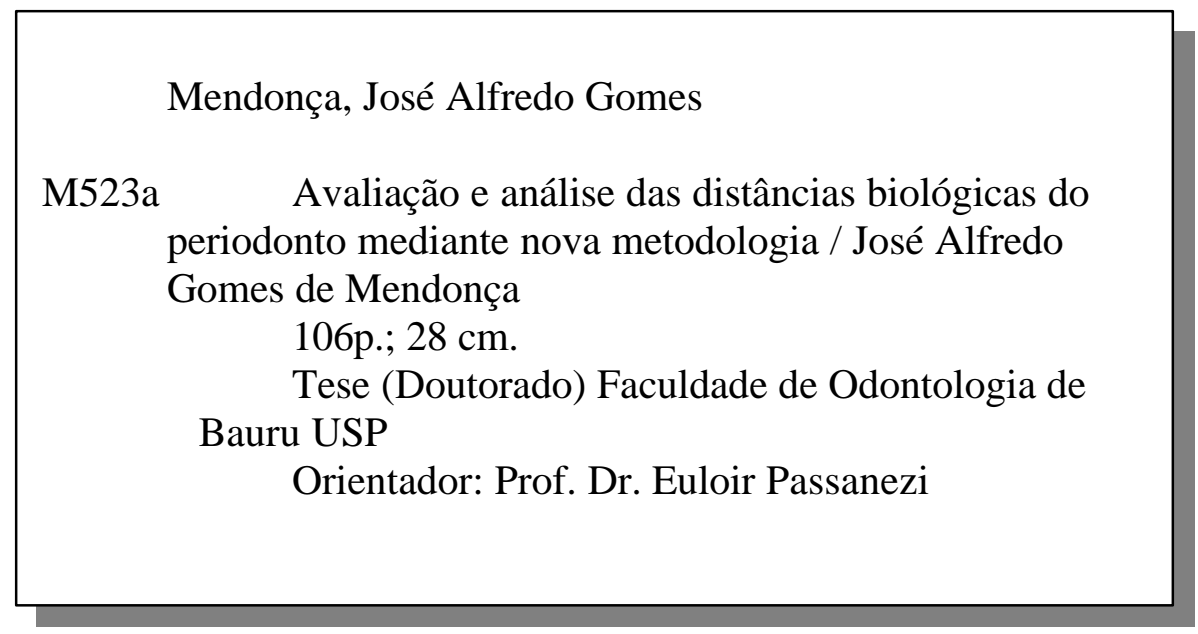

Autorizo, exclusivamente para fins acadêmicos e científicos, a reprodução total ou parcial desta tese, por processos fotocopiadores e outros meios eletrônicos.

Assinatura:

Bauru, 06 de Março de 2001. 


\section{DADOS CURRICULARES}

\section{JOSÉ ALFREDO GOMES DE MENDONÇA}

11 de maio de 1960, em Belo Horizonte José Vieira de Mendonça Sobrinho Ana Júlia Gomes de Mendonça 1981 - 1984

$1986-1987$

$1987-1991$

1989

$1990-1991$

$1992-1996$

$1996-2001$

$1997-2000$

$1997 \ldots$

$2001 \ldots$

Associações
Nascimento.

Filiação.

Curso de Graduação na Faculdade de Odontologia da Fundação de Ensino Superior de Itaúna - FENSUPI - MG.

Curso de Especialização em Prótese Dental no Centro de Estudos Odontológicos do Instituto de Previdência de Minas Gerais - CEO IPSEMG.

Professor Responsável da Disciplina de Prótese Dental da Faculdade de Odontologia da Fundação de Ensino Superior de Itaúna MG.

Curso de Especialização em Radiologia pela FOB - USP.

Curso de Especialização em Periodontia pela FOB - USP.

Curso de Mestrado em Periodontia na Faculdade de Odontologia de Bauru - USP

Doutorando em Periodontia na Faculdade de Odontologia de Bauru - USP

Professor Assistente do Departamento de Clínica, Patologia e Cirurgias Odontológicas da Faculdade de Odontologia da Universidade Federal de Minas Gerais

Sub-Coordenador do Curso de Especialização em Periodontia da ABO-Goiás

Coordenador do Curso de Pós-Graduação em Implantodontia da Pontifícia Universidade Católica-MG

ABO-MG - Associação Brasileira de Odontologia - Secção Minas Gerais

CRO-MG - Conselho Regional de

Odontologia de Minas Gerais - no 12.009

IADR - International Association for Dental Research

SOBRAPE - Sociedade Brasileira de Periodontia 
A DEUS,

Santa Apolônia,

$$
\begin{gathered}
\text { e meus "anjos da guarda": } \\
\text { Vovô Zequinha } \\
\text { Vó Santinha } \\
\text { Nanael } \\
\text { Dudu }
\end{gathered}
$$

pelos momentos de proteção e vigília... 


\section{DEDICATÓRIA}

A Ana Paula, minha esposa, amiga e companheira, que em todos os momentos acreditou neste projeto e comigo viveu e suportou todas as incertezas. Que eu possa agora, no final desse caminho, retribuir com meu amor e minha gratidão toda a sua abdicação pessoal em prol dessa jornada.

Às minhas filhas Fernanda e Gabriela (a "Gabinanda"), luzes radiantes de pureza e simplicidade que me foram confiadas com a bênção de Deus, a certeza de que toda a luta tenha sido válida como subsídio de maturidade e serenidade, afim de que possa dar a elas uma formação como a que foi a mim transmitida pelos meus pais.

Aos meus pais, José e Ana Júlia, por todo o amor e exemplo com que moldaram meu caráter à sua semelhança, toda a minha gratidão! Gratidão pela vida, pelo amor e pela convivência. Nada que se diga poderá expressar este amor e a admiração.

Àqueles aos quais eu tenho imenso amor, cada um em sua forma e intensidade, que mesmo no reconhecimento de toda a minha falibilidade, em cujas mentes sempre estive presente em forma de orações e pensamentos, minha eterna gratidão por todos os momentos que me permitiram crescer, viver e amar...

eu dedico este trabalho 
Aos irmãos Luís Fernando, Carmem Lúcia (aos sobrinhos Ana Laura e Luís Henrique), o reconhecimento da profunda amizade e solidariedade na qual construímos pouco a pouco nossa relação. Que todo o amor que possa dar venha frutificar e estreitar a cada dia essa irmandade até o fim dos nossos tempos. Que nossos filhos sejam amigos e que os filhos dos nossos filhos possam se referir a nós com respeito e admiração por tudo o que fizemos...

Aos meus irmãos: Jupira, Leopoldo, Moema, Iberê, Dorotéia, Ubirajara, Fatinha, Ubiratan, Erenita, Tibiriçá e Ana Livia, aos meus afilhados Luís Paulo e Arthur assim como a todos os meus sobrinhos, por todos os momentos felizes que estivemos e que vamos desfrutar juntos, todo o meu amor.

À família Cançado: Seu José Cançado, Da. Aparecida, Paulinho, Adriana, Ivan, Cristina, Flávio, Marcelo, Viviane, Mário Lúcio (in memórian), Dudu (in memórian), Maria Angélica e a todos os sobrinhos, pelo carinho de filho, irmão e tio que sempre me dispensaram.

À Míria Márcia, Antônio, Luciene, Margareth e Luzia pela amizade e união em todos esses anos em que trabalhamos juntos em busca do mesmo ideal, toda a minha gratidão e admiração.

Aos colegas Antônio Loureiro Leandro, o "Tuneca", que me incentivou, ainda na adolescência, a ser cirurgião dentista e Valdete da Costa, que me incentivou a ser periodontista, minha gratidão pelos anos em que me acolheram em seus consultórios.

Aos ex-alunos orientados do Curso de Especialização em Periodontia da Associação Brasileira de Odontologia - Sessão Goiás: Cláudio Heleno Guimarães, Carlos Augusto Nazareth e Maria das Graças Cruz Najar; cujos trabalhos de Monografia forneceram subsidios para a confecção deste trabalho. 


\section{AGRADECIMENTOS}

Ao Professor Doutor Euloir Passanezi, Coordenador do Curso de Doutorado em Periodontia, pela transmissão de seus inesgotáveis conhecimentos, pelo tratamento amigo e pela acolhida em seu consultório. Sua dedicação à docência e à profissão como um exemplo de lisura e retidão de princípios me fez ver e crer, em todos esses anos, de que sempre vale a pena. Ser coerente e ter caráter sempre dignificou sua imagem e o qualificou como o exemplo a ser seguido.

Minha eterna gratidão.

Ao Professor Doutor Deoclécio Nahás, pelos ensinamentos transmitidos, pelos momentos de convívio e pela amizade.

Minha eterna gratidão.

Ao Professor Doutor Sebastião Luiz Aguiar Greghi, pelos ensinamentos transmitidos, pelo tratamento sincero de professor e colega.

Minha eterna gratidão.

As pessoas passam, as Instituições permanecem.

Àqueles que as dignificaram, o nosso reconhecimento e respeito.

Aos que as desonraram, nosso repúdio à deficiência de caráter e pobreza de espírito... 


\section{AGRADEÇO AINDA}

À Comissão de Pós-Graduação da Faculdade de Odontologia de Bauru, USP, na pessoa do seu presidente, Prof. Dr. Luís Antônio Pegoraro;

A todos os professores da Faculdade de Odontologia de Bauru, que de alguma maneira contribuíram com a minha formação profissional;

Aos amigos de Mestrado Emildre, Miguel, Mário e Daniela, pela convivência, companheirismo e solidariedade que jamais serão esquecidos;

À amiga Nirene, Professora de Língua Portuguesa, pela contribuição dada neste trabalho;

Aos funcionários Maria Ângela, Ivânia, Ester, Adriane, Neusa e Marcos, pela amizade e colaboração;

Aos amigos da biblioteca, Maria Helena, Célia, Cybelle, Ademir, Maria, Roberto, Leni e Valéria, que sempre nos têm auxiliado de forma prestativa e amiga. Seus exemplos deixarão saudades;

Aos colegas de Pós-Graduação do departamento de Periodontia e da Faculdade de Odontologia de Bauru. 
SUMÁRIO 


\section{SUMÁRIO}

\begin{tabular}{|c|c|}
\hline RESUMO & p.viii \\
\hline 1 INTRODUÇÃO & 1 \\
\hline 2 REVISÃO DA LITERATURA & 5 \\
\hline 2.1 ASPECTOS MORFOFISIOLÓGICOS DO PERIODONTO & 5 \\
\hline 2.1.1 PERIODONTO DE PROTEÇÃO & 5 \\
\hline 2.1.1.1 GENGIVA & 5 \\
\hline 2.1.1.2 SULCO GENGIVAL & 14 \\
\hline 2.1.1.3 EPITÉLIO JUNCIONAL & 15 \\
\hline 2.1.1.4 INSERÇÃO CONJUNTIVA & 18 \\
\hline 2.1.2 PERIODONTO DE SUSTENTAÇÃO & 21 \\
\hline 2.1.2.1 OSSO ALVEOLAR & 21 \\
\hline 2.1.2.2 LIGAMENTO PERIODONTAL & 22 \\
\hline 2.1.2.3 CEMENTO & 23 \\
\hline 2.2 DISTÂNCIAS BIOLÓGICAS & 24 \\
\hline 2.3 A SONDA PERIODONTAL & 27 \\
\hline 2.4 AVALIAÇÃO DA INFLAMAÇÃO NOS TECIDOS GENGIVAIS & 33 \\
\hline 3 PROPOSIÇÃO & 35 \\
\hline 4 MATERIAL E MÉTODOS & 36 \\
\hline 4.1 SELEÇÃO DE PACIENTES & 36 \\
\hline 4.2 PADRONIZAÇÃO DA AMOSTRA & 39 \\
\hline 4.3 COLETA DE DADOS & 39 \\
\hline 4.3.1 ESPESSURA DA MUCOSA GENGIVAL MARGINAL & 40 \\
\hline 4.3.2 LARGURA DA MUCOSA CERATINIZADA & 49 \\
\hline 4.3.3 PROFUNDIDADE DE SONDAGEM CLÍNICA & 51 \\
\hline 4.3.4 ÍNDICE DE SANGRAMENTO GENGIVAL & 53 \\
\hline 4.3.5 DISTÂNCIA MARGEM GENGIVAL-CRISTA ÓSSEA & 54 \\
\hline 4.3.6 ESPESSURA DA CRISTA ÓSSEA & 58 \\
\hline 5 RESULTADOS & 59 \\
\hline 5.1 PARTE DESCRITIVA OU EXPLORATÓRIA (CARACTERIZAÇÃO DA AMOSTRA) & 59 \\
\hline 5.2 ANÁLISE DA ASSOCIAÇÃO DAS VARIÁVEIS ESTUDADAS & 70 \\
\hline 6 DISCUSSÃO & 78 \\
\hline 6.1 PARTE DESCRITIVA OU EXPLORATÓRIA (CARACTERIZAÇÃO DA AMOSTRA) & 82 \\
\hline 6.2 ANÁLISE DA ASSOCIAÇÃO DAS VARIÁVEIS ESTUDADAS & 87 \\
\hline 6.3 ANÁLISE GLOBAL & 92 \\
\hline 7 CONCLUSÕES & 97 \\
\hline REFERÊNCIAS BIBLIOGRÁFICAS & 99 \\
\hline ABSTRACT & 105 \\
\hline
\end{tabular}


RESUMO 


\section{RESUMO}

A multifatoriedade da causa da doença periodontal dificulta sobremaneira o diagnóstico, prognóstico e plano de tratamento. Com o desenvolvimento da biotecnologia dos materiais, acreditamos que a solução para o tratamento das sequelas da doença periodontal esteja próxima de um desfecho favorável ao clínico e ao paciente. Os métodos de controle da doença periodontal ainda são limitados e o surgimento de equipamentos de alta sensibilidade se faz necessário para viabilizar a detecção prévia da perda de inserção. Os parâmetros das distâncias biológicas preconizadas por Gargiulo e colaboradores, atualmente ditam os protocolos dos procedimentos protéticos, estéticos, cirúrgicos e de manutenção dos pacientes periodontalmente tratados, com a finalidade de garantir a homeostasia dos periodontos de sustentação e proteção. Foram realizados por um único operador 396 medidas em 66 dentes adjacentes de 32 pacientes que se submeteriam à tratamento de fixação de implantes osseointegrados, sem distinção de raça ou sexo, com idade compreendida entre 15 e 68 anos, 13 do sexo masculino e 19 do sexo feminino, 4 fumantes e 28 não fumantes. O objetivo da investigação foi analisar a espessura dos tecidos moles com o uso do equipamento SDM - (técnica não invasiva), correlacionando-o com parâmetros já conhecidos para análise das distâncias biológicas como: profundidade de sondagem clínica manual, espessura da crista óssea, distância da margem gengival até o nível ósseo e índice dicotômico de sangramento à sondagem, na tentativa de determinar uma correlação mais acurada entre os parâmetros já conhecidos das distâncias biológicas dos periodontos de proteção e sustentação. Pelos resultados obtidos, concluiu-se neste trabalho que uma crista óssea fina suporta tecido com conteúdo de 
colágeno mais frágil e condição homeostática pior; a distância da margem gengival à crista óssea apresentou uma média ligeiramente inferior a $2.73 \mathrm{~mm}$ encontrada por GARGIULO e colaboradores ${ }^{13}$, ficando na casa dos 2,507mm; as distâncias biológicas nos dentes anteriores são maiores do que nos dentes posteriores; a largura da mucosa ceratinizada é maior nos incisivos e caninos em relação a pré-molares e molares. Existem fortes correlações entre: a profundidade de sondagem e a espessura da mucosa ceratinizada; a profundidade de sondagem e a distância da margem gengival até a crista óssea; a largura e a espessura da mucosa ceratinizada; a profundidade de sondagem (PS) e a distância da margem gengival à crista óssea para os incisivos e caninos. Nos sítios com espessura óssea normal existe uma forte correlação entre a profundidade de sondagem e a distância da margem gengival-crista óssea, assim como entre a largura da mucosa ceratinizada e distância da margem gengival-crista óssea. Nos sítios com espessura óssea grossa, quanto maior a profundidade de sondagem, maior a espessura da mucosa ceratinizada.Quando o índice gengival=0, a espessura da mucosa ceratinizada apresenta também uma forte correlação com a profundidade de sondagem e com a largura da mucosa ceratinizada. 
1 INTRODUÇÃO 


\section{1 - INTRODUÇÃO}

Por séculos, de acordo com os registros encontrados nos relatos chineses e egípcios, o homem teve a preocupação de desvendar os mistérios que levam às doenças gengival e periodontal e por consequência à perda dos dentes.

Mesmo nos dias de hoje, a despeito dos esforços científicos para o diagnóstico e tratamento da doença periodontal, pode-se notar que ainda há limitações ao tratamento curativo em detrimento do tratamento preventivo, o que não tem sido observado na doença cárie.

No afã de tratar a doença periodontal marginal infecciosa, os recursos costumeiramente utilizados na clínica de periodontia têm sido amplamente modificados nas últimas décadas, porém ainda se procura limitar a perda de inserção periodontal, tentando compreender a etiologia e a patogenia da doença, assim como a ação das bactérias em relação ao hospedeiro que as abriga. E mais: perceber que elas atuam de formas diferentes em pacientes diferentes assim como em diferentes sítios no mesmo indivíduo, têm agressividade diferente em períodos diferentes da vida deste mesmo hospedeiro e que inúmeras variáveis estão condicionadas à essa perda óssea.

Esta multifatoriedade da causa da doença periodontal dificulta sobremaneira o diagnóstico, prognóstico e plano de tratamento. Com o desenvolvimento da biotecnologia dos materiais (enxertos ósseos não autógenos, fatores de crescimento, barreiras mecânicas de reabsorção controlada), é de se crer que a solução para o tratamento das sequelas da doença periodontal esteja próxima de um desfecho favorável ao clínico e ao paciente. Entretanto, muito mais se almeja da ciência para oferecer ao ser 
humano, ou seja, idealmente devem ser buscados métodos de prevenção da doença periodontal e, quando instalada a doença, métodos de detecção precoce e de controle pós-terapia. Portando, é de fundamental importância detectar pacientes de risco, sítios de risco e períodos de risco de perda de inserção periodontal.

As técnicas e tecnologias apresentadas até hoje ainda estão fora de alcance da grande maioria dos clínicos, sendo observadas apenas nos multicentros de pesquisa. Dentre elas podemos enumerar: a) análise e controle de perda de nível de inserção através da sondagem eletrônica; b) análise da temperatura gengival; c) controle dos níveis de inserção através da radiografia digitalizada e radiografia de subtração; d) análise da microbiota e sua patogenia através de dispositivos químicos e laboratoriais, dentre outros. Ainda assim, a eficácia destas técnicas ainda é questionável no que se refere ao controle prévio da doença periodontal.

Neste contexto parece realçar a importância da relação entre as distâncias biológicas propostas por MAYNARD \& WILSON ${ }^{32}$ em 1979, necessárias para a expressão da saúde periodontal

Uma definição mais acurada das dimensões do espaço biológico foi possível graças às pesquisas de GARGIULO et al. ${ }^{13}$ em materiais de autópsia, determinando uma zona do periodonto marginal com valores médios de 2,04 mm que não deveria ser invadida por procedimentos restauradores, pois seria destinada à união biológica dos tecidos periodontais com a superfície dental. Estes parâmetros atualmente ditam os protocolos dos procedimentos protéticos, cirúrgicos e de manutenção dos pacientes periodontalmente tratados, com a finalidade de garantir a homeostasia dos periodontos de sustentação e proteção. 
A colocação de restaurações e próteses subgengivais na tentativa de esconder o término das cintas metálicas está baseada em conceitos estabelecidos em análises de cadáveres, que resultaram em medidas médias das distâncias biológicas. Nesta análise, pouco foi verificado no que se refere ao relacionamento entre a espessura da mucosa e osso alveolar que pode ter influência direta sobre as dimensões das distâncias que vão da margem gengival até a crista óssea e conseqüentemente nas dimensões do sulco gengival resultante. Aliás, SCHLUGER $^{43}$ et al. deixam transparecer essa provável influência no capítulo de cirurgia mucogengival em seus livros de texto. A existência de um aparelho ou de uma forma não invasiva para avaliar a espessura óssea e/ou gengival poderia melhorar tanto os resultados estéticos assim como limitar a profundidade dos preparos restauradores limitando, consequentemente, fenômenos inflamatórios. A determinação do limite cervical de preparos cavitários subgengivalmente, considerado um "dogma" no tratamento protético restaurador, pode resultar em casos de processos inflamatórios locais por invasão de distâncias biológicas. Em outras situações, pode-se observar uma tolerância biológica mais aceitável com um resultado estético superior. Tudo dependerá das condições anatômicas locais como: profundidade e amplitude do sulco gengival, qualidade e quantidade de mucosa ceratinizada, epitélio juncional, inserção conjuntiva, espessura óssea, dentre outros.

Neste trabalho analisaremos a eficácia do uso do sonar para análise da espessura dos tecidos moles - SDM - (técnica não invasiva), correlacionando-o com parâmetros já conhecidos para análise das distâncias biológicas como: profundidade de sondagem clínica manual, espessura da crista óssea, distância da margem gengival até o nível ósseo e índice de 
sangramento à sondagem, na tentativa de determinar uma correlação mais acurada entre os parâmetros já conhecidos das distâncias biológicas dos periodontos de proteção e sustentação (neste particular, a crista óssea alveolar). 
2 REVISÃO DA LITERATURA 


\section{REVISÃO DA LITERATURA}

Neste capítulo serão apresentados inicialmente trabalhos que ilustram as características estruturais e funcionais dos tecidos que compõem o periodontium como um todo, para se poder correlacionar a importância da preservação da harmonia funcional desses integrantes na manifestação contínua da homeostasia periodontal.

Isto posto, serão apresentadas considerações sobre as implicações do volume gengival marginal sob a forma de distâncias biológicas e a maneira pela qual se tem extrapolado clinicamente alterações processadas na profundidade de sondagem do sulco gengival ou bolsa periodontal.

\subsection{ASPECTOS MORFOFISIOLÓGICOS DO PERIODONTO}

Periodontium literalmente significa "ao redor do dente" cuja principal função é inserir o dente no tecido ósseo dos maxilares e manter a integridade da superfície da mucosa mastigatória da cavidade bucal ${ }^{24}$.

Funcionalmente as estruturas periodontais são englobadas em periodonto de proteção e sustentação:

\subsubsection{PERIODONTO DE PROTEÇÃO}

\subsubsection{GENGIVA}

A cavidade bucal é revestida por uma mucosa que se estende anteriormente até a pele do lábio e posteriormente a mucosa do palato mole e da faringe. A mucosa oral tem 3 componentes: a mucosa mastigatória que cobre o palato duro e o osso alveolar, a mucosa especializada que cobre o dorso da língua e a mucosa de revestimento que compreende o restante da mucosa bucal. 
BOWERS $^{8}$ (1963), medindo a largura de gengiva inserida ao subtrair a profundidade de sondagem da largura total de mucosa ceratinizada (margem gengival para junção-mucogengival), verificou uma variação de 1 a $9 \mathrm{~mm}$ e que gengiva saudável era encontrada em regiões de $1 \mathrm{~mm}$ de gengiva ceratinizada e que o tecido era normalmente inflamado em áreas de nenhuma gengiva ceratinizada. Pôde-se conceber que esta quantidade de gengiva ceratinizada varia de pessoa para pessoa e de uma área para outra, sendo definida por diferentes fatores anatômicos e biológicos relacionados com o nível da margem gengival, porém sem alteração no nível da junção mucogengival. Estes resultados também foram corrobados por AINAMO; LÖE ${ }^{4}(1966)$, AINAMO; TALARI ${ }^{5}$ (1976), AINAMO ${ }^{1}$ (1978), AINAMO; AINAMO $^{2}(1978)$.

Algum tempo depois do trabalho de BOWERS ${ }^{8}$, LANG \& LÖE $^{21}$ (1972) verificaram variação no índice de exsudato gengival em indivíduos com boa performance de higiene bucal, porém que apresentaram faixa de gengiva ceratinizada abaixo ou acima de $2 \mathrm{~mm}$. Essas observações foram sugestivas de que a zona da gengiva ceratinizada influencia o comportamento fisiológico do sulco gengival.

GOASLIND $^{15}$ et al. (1977) avaliando espessuras de gengiva livre, calcularam média de $0,39 \mathrm{~mm}$ a $1,56 \mathrm{~mm}$, que aumentou de anteriores para posteriores e era diretamente proporcional à profundidade do sulco gengival. Observaram que a gengiva completamente normal preenche o espaço vazio entre os dentes como gengiva interdental ou papila gengival e que a altura coronal da papila localiza-se medialmente na porção apical da área de contato entre dois dentes adjacentes. No segmento anterior da dentição, dependendo da largura do espaço interdental, a gengiva interdental 
assume forma cônica ou piramidal, e é denominada papila interdental. Geralmente a superfície papilar é queratinizada.

WAERHAUG $^{55}$ (1978) estudando a cicatrização da junção dento-epitelial propôs que a obtenção de melhor comportamento homeostático do periodonto marginal é observada quando se tem sulcos gengivais rasos, sendo praticamente impossível manter a higiene bucal em áreas com profundidades clínicas de exploração do sulco gengival acima de $3 \mathrm{~mm}$.

GOLDMAN $^{16}$ (1983) relatou que nos dentes completamente erupcionados, a margem gengival está localizada no esmalte cerca de 0,5 a 2 $\mathrm{mm}$ coronalmente ao colo. Nos dentes humanos, propôs que a margem gengival raramente forma um bisel contra o dente, sendo ao contrário arredondada e em geral formando um canal raso com a margem gengival e a superfície do dente, correspondente à entrada ou orifício do sulco gengival.

LINDHE $^{24}$ (1989) descreveu que, didaticamente, a gengiva é dividida em gengiva livre e gengiva inserida. A linha divisória entre as duas é uma linha imaginária entre o fundo do sulco gengival e a superfície gengival visível oposta a ele. A gengiva inserida estende apicalmente deste ponto até a junção mucogengival.

LINDHE $^{24}$ (1989) descreveu que a gengiva é a porção da mucosa bucal que cobre o osso alveolar e se insere na região cervical dos dentes.

RATEITSCHAK ${ }^{42}$ et al. (1989) considerou que a largura da gengiva inserida varia consideravelmente de dente para dente e entre indivíduos. Embora tenha relatado que uma largura mínima de gengiva 
inserida $( \pm 2 \mathrm{~mm})$ é necessária para manter a saúde periodontal, esta visão foi revisada durante recentes anos e alguns autores ${ }^{1,4,22}$ consideram que não há largura mínima absoluta de gengiva inserida que seja requerida para saúde periodontal. Aceitou-se que a superfície da gengiva freqüentemente exibe uma aparência de casca de laranja chamada Stipling, porém, apesar de previamente muitos clínicos considerarem a gengiva sem pontilhado como um sinal de alteração patológica, atualmente é amplamente aceitável que a gengiva sem pontilhado possa exibir características idênticas àquelas perfeitamente saudáveis e que possuem pontilhado. A gengiva marginal livre (não inserida) foi definida como a margem ou bordo da gengiva que circunda os dentes em forma de um colar. Em aproximadamente 50\% dos casos delimita com a gengiva inserida adjacente através de uma depressão linear rasa, o sulco gengival livre.

RAMFJORD; $\mathrm{ASH}^{40}$ (1991) consideraram que a zona mais ampla de gengiva inserida é encontrada nas regiões anteriores e diminui dos caninos para distal estando a zona mais estreita de gengiva inserida no aspecto vestibular dos primeiros pré-molares inferiores, enquanto no palato não há distinção anatômica ente gengiva inserida e a mucosa palatina. A largura da gengiva inserida tende a aumentar com a idade se não houver resseção gengival. Parece que a posição da linha mucogengival relativa ao limite inferior da mandíbula é constante com o tempo, de modo que o aumento da gengiva inserida se dá com a erupção compensatória fisiológica dos dentes.

TARNOW; MAGNER; FLECTCHER ${ }^{49}$, (1992) verificaram que o volume gengival na área interproximal pode alcançar dimensões maiores do que as distâncias biológicas propostas por GARGIULO ${ }^{13}$ et al. 
HASSEL $^{19}$ (1993) relatou que a gengiva normal possui coloração rósea (rosa salmão ou coral) e está demarcada apicalmente da mucosa alveolar (usualmente de coloração vermelho escura) por uma linha mucogengival a qual é mais ou menos evidente clinicamente, dependendo do grau de queratinização e pigmentação da gengiva. $O$ acúmulo de pigmentação melânica na gengiva também foi considerada normal, variando de indivíduo para indivíduo e sendo mais freqüentemente observado em negros e raramente em orientais e caucasianos. Considerou a gengiva como a porção de tecido que se estende coronalmente a partir da linha mucogengival e que está firmemente aderida ao periósteo pelas fibras colágenas. Concordou que a largura coronoapical da gengiva inserida pode variar significantemente de um dente para outro e entre diferentes indivíduos, tendendo a tornar-se extensa com a idade. No segmento posterior da boca, onde a área de contato entre os dentes é usualmente ampla, mencionou-se que a gengiva interdental consiste de 2 papilas, uma vestibular e outra lingual, ambas conectadas pelo "Col" que corresponde a uma depressão recoberta por epitélio não ceratinizado representando essencialmente a fusão do epitélio juncional interproximal dos dois dentes adjacentes. Enfatizou tratar-se de uma estrutura que é particularmente susceptível às substâncias nocivas ou trauma físico, e representar o sítio mais freqüente para o desenvolvimento de processos patológicos no aparato de suporte do dente. Onde os dentes adjacentes não possuem contato ou quando um dente é perdido do arco dentário, a gengiva inserida ceratinizada percorre ininterruptamente através do rebordo alveolar no sentido vestíbulolingual e em situações na qual a papila interdental e o col estão ausentes. $\mathrm{O}$ epitélio gengival tem sido descrito como o tegumento protetor do periodonto e assim sua aparência histológica humana tem sido estudada com grande 
detalhe e descrito por numerosos autores. ${ }^{1,2,10,22,23,24,44}$ A gengiva marginal e inserida são cobertas por uma típica camada de epitélio estratificado pavimentoso ceratinizado, constituído de 04 estratos epiteliais clássicos: basal, espinhoso, granuloso e córneo. O estrato basal representa a camada germinativa; suas células são principalmente cuboidais e aderidas à lâmina basal pelos chamados hemidesmossomos. As células basais são também aderidas, lateralmente umas às outras por junções tipo fenda e hemidesmossomos; interdigitações elaboradas da membrana plasmática das células basais freqüentemente aparecem na lateral das células que se encontram aproximadas. As células que se destinam a atravessar o epitélio e a ceratinizá-lo são conhecidas como ceratinócitos. Estas células exibem duas funções primárias: auto-replicação, servindo como fonte contínua de novas células para a constante renovação do tecido, e produção e secreção dos materiais que formam a lâmina basal. O tempo de renovação celular no epitélio gengival é similar ao observado em outros epitélios de superfície. O tempo necessário para as células basais neoformadas alcançarem a superfície é de 10 a 12 dias. O estrato espinhoso mostra células com aspectos característicos de especialização e maturação aumentada. As células da camada espinhosa têm uma taxa mitótica diminuída em relação às células da camada basal, e perdem presumivelmente a capacidade de sintetizar e secretar material da lâmina basal. Nas regiões superficiais da camada, as células contêm glicogênio e grânulos citoplasmaticos periféricos, densos corpos de Odland ou grânulos revestidores de membrana. As junções tipo fendas alongadas são predominantes também. Nas células granulosas os desmossomos predominam, o tamanho do espaço intercelular é reduzido e as interdigitações celulares são menos proeminentes do que nas camadas mais profundas do epitélio. À medida que se aproxima da zona de ceratinização as 
uniões desmossômicas tornam-se fortalecidas por longos trechos de junções apertadas (tight juntions) e abertas (gaps).

O estrato córneo apresenta células que se aproximam da camada mais externa do epitélio bucal, sendo que o processo de ceratinização vai se completando à medida que as células são transformadas em ceratinócitos, os quais se apresentam achatados, paralelos à superfície da gengiva e sem núcleos. Além disso, a maioria dos componentes de síntese intracelulares (tais como complexo de Golgi, reticulo endoplasmático e mitocôndrias) é perdida, resultando em uma célula epitelial preenchida por ceratina. Apesar das alterações repentinas e distintas que ocorrem intra e extracelulamente no contorno e configuração celulares, reflexos da degradação celular, a ligação entre as células ainda permanece em grande parte intacta no estrato córneo.

Assim, à medida que as células caminham da camada basal até a superfície, sofrem contínua diferenciação e maturação sendo resumido como:

1) perda da capacidade mitótica e de sintetizar e secretar material da lâmina basal;

2) produção intensificada de proteína com acúmulo de filamento citoplasmático, matriz amorfa e grânulos ceratohialinos;

3) decomposição gradativa do aparelho de síntese e de produção de energia;

4) formação de uma capa córnea por ceratinização celular;

5) manutenção das junções celulares laterais; e 
6) perda eventual da inserção celular, levando à descamação das células da superfície.

Um outro tipo de célula tipicamente observado no extrato basal é o melanócito, uma célula estrelada com numerosos processos dendríticos que está presente em densidade aparentemente constante entre indivíduos e raças. Os melanócitos não estão aderidos nem a lâmina basal subjacente e nem as células adjacentes do estrato basal. A única função conhecida dos melanócitos é a produção de melanina, um pigmento que serve para proteger contra os efeitos ionizantes da radiação eletromagnética, e para distribui-los aos ceratinócitos. O processo de transferência ocorre via fagocitose, pelos ceratinócitos da extremidade do processo melanocítico do melanócito. A intensidade da cor da pele e gengiva é determinada pelo número e padrão de agregação da melanina presente dentro dos ceratinócitos. Ainda um outro residente do epitélio gengival é a célula de Langerhans, a qual deriva de célula progenitora na medula óssea.

DIFRANCO $^{12}$ et al. referriram-se à célula de Langerhans como células de vigilância imune, considerando que o número delas aumenta em tecido inflamado ( 2 a 10 vezes) e que provavelmente migram do tecido conjuntivo subjacente em resposta ao desafio antigênico. Foi postulado que as células de Langerhans apresentam antígenos de superfície semelhante aos linfócitos T e macrófagos, e constituindo uma das primeiras linhas de defesa contra a penetração de antígenos no hospedeiro. Para que o tecido possa exercer sua função de promover a proteção às estruturas periodontais adjacentes, o epitélio gengival apoia-se sobre e está intimamente associado a uma membrana basal, que separa o epitélio do compartimento de tecido conjuntivo gengival, imediatamente subjacente (lâmina própria). O 
microscópio eletrônico revela esta membrana basal como constituída por uma lâmina basal apresentando duas camadas distintas: a lâmina lúcida e a lâmina densa. A lâmina lúcida está em contato imediato com as células epiteliais do estrato basal, às quais se conecta via hemidesmossomos, ao passo que a lâmina densa entra em contato com o compartimento de tecido conjuntivo e está unida firmemente a ele por meio de fibrilas, que têm sido descritas como originárias dos hemidesmossomos das células basais do epitélio, atravessando a membrana basal e terminando na camada mais superficial do tecido conjuntivo. Assim, a membrana basal separa o epitélio bucal do tecido conjuntivo e proporciona uma camada confluente que conecta o epitélio ao tecido conjuntivo. (HASSEL $\left.{ }^{19}, 1993\right)$. Por meio de seus componentes de natureza glicoproteica, como o sulfato de heparina (ALBREKTSSON; ZARB, 1990), a membrana basal funciona como um filtro seletivo de substâncias que possam passar do epitélio para o conjuntivo ou que passam do conjuntivo para o epitélio, inclusive os nutrientes.

Preocupado com o valor da gengiva ceratinizada no comportamento periodontal marginal, HALMON ${ }^{17}$ et al. (1996) compararam os resultados do controle de placa dental bacteriana em pacientes submetidos ou não a enxertos autógenos livres de gengiva. Após 6 anos observaram resultados similares em ambos os lados, porém com algum ganho de inserção no lado do enxerto e alguma recessão no lado sem enxerto. Além disso, em um grupo de pacientes que não foi mantido sob controle profissional de placa dentobacteriana, os resultados mostraram a preservação das características periodontais homeostáticas no lado em que foi feito o enxerto de gengiva, enquanto que no lado controle houve formação de placa 
dentobacteriana e alteração periodontal. Tais aspectos ilustram a importância da gengiva ceratinizada no comportamento homeostático marginal.

\subsubsection{SULCO GENGIVAL}

TEN CATE $^{52}$ (1985) considerou o sulco gengival como uma ranhura pouco profunda entre o dente e a gengiva normal, estendendo-se desde a superfície livre do epitélio juncional coronalmente até o nível da margem gengival livre. A profundidade clínica do sulco foi proposta variando de 0,5 a 3,0 $\mathrm{mm}$ com profundidade média de 1,8 $\mathrm{mm}$. Também propôs que no dente em função o fundo do sulco está geralmente localizado na metade cervical da coroa anatômica, mas com a idade experimenta migração gradual em direção apical podendo atingir a superfície do cemento. Descreveu o orifício do sulco gengival como formado de um lado pela superfície do dente e do outro pelo epitélio sulcular ficando o fundo do sulco freqüentemente circundado por epitélio de todos os lados, o que se deveria à persistência de células do epitélio juncional na superfície do dente, por uma distância de aproximadamente 100 micrômetros coronalmente ao fundo do sulco.

CARRANZA $\mathrm{Jr}^{10}$ (1992) relatou que o epitélio sulcular tem o potencial de ceratinizar se for refletido e exposto à cavidade bucal, ou se a flora bacteriana do sulco for totalmente eliminada. Estes achados sugeriram que a irritação local do sulco impede a sua ceratinização. Considerou o epitélio sulcular extremamente importante porque pode agir como uma membrana semipermeável através da qual produtos bacterianos prejudiciais passam para dentro da gengiva e o fluído tissular é exsudado para dentro do sulco. 
HASSEL $^{19}$ (1993) descreveu o epitélio sulcular oral como a extensão do epitélio gengival, tendo como limite coronário a altura da gengiva marginal livre e como limite apical a superfície do epitélio juncional; assim considerou o epitélio sulcular oral como uma parede lateral do sulco gengival. Também aceitou que o epitélio sulcular oral exibe os mesmos 4 estratos epiteliais vistos no epitélio gengival oral, mas uma camada ceratinizada definitiva e contínua é ausente. Embora a superfície do epitélio sulcular oral possa, algumas vezes, exibir um grau de paraceratinização, uma característica primária distinguível entre ele e o epitélio gengival oral é que o epitélio sulcular não ceratiniza. Considerou que a transmigração leucocitária é observada raramente no epitélio sulcular oral devido a sua falta de permeabilidade.

\subsubsection{EPITÉLIO JUNCIONAL}

SCHLUGER $^{43}$ (1990) designou como epitélio juncional o tecido unido ao dente de um lado e o epitélio sulcular oral ou tecido conjuntivo do outro. O epitélio juncional forma a base do sulco gengival e tem sido examinado em detalhe por vários investigadores. Sua estrutura e função diferem significativamente do epitélio gengival; certamente, em muitos aspectos o epitélio juncional parece ser um sistema biológico único. As células do epitélio juncional dispõe-se somente nas camadas basal e suprabasal e não mostram tendência a amadurecer e a formar as camadas granulosa e córnea. As células organizam-se a partir da camada basal, migram em direção oblíqua para a superfície do dente e eventualmente alcançam a base do sulco gengival, de cuja superfície livre descamam-se. As células do epitélio juncional mostram aspectos citológicos pouco comuns, diferindo acentuadamente de outros epitélios. As células basais são cúbicas, 
ou, em alguns casos achatadas e, em relação às células do epitélio gengival, contêm maior quantidade de reticulo endoplasmático rugoso e menos filamentos citoplasmáticos. Após deixar a camada basal, as células tornamse extremamente achatadas e os núcleos alongados em direção paralela ao longo eixo da superfície dentária. Entretanto as células não sofrem maior modificação citológica após deixar a camada basal, exceto que alteram sua forma. As células da camada suprabasal, inclusive as adjacentes à superfície do dente, exibem interdigitação e formação de microvilosidades complexas. Leucócitos são observados dentro do epitélio juncional mesmo em gengivas clinicamente normais e a presença de pequeno número deles é considerada normal. Leucócitos polimorfonucleares entram no epitélio juncional vindo dos vasos do tecido conjuntivo subjacente, migrando pelos espaços intercelulares e indo ao sulco gengival. Muitas células linfóides, especialmente pequenos linfócitos, são observadas dentro do epitélio juncional de gengiva clinicamente normal junto a algumas células com características de macrófagos.

\footnotetext{
RATEITSCHAK; WOLF; HASSELL ${ }^{42}$ (1989) relataram o epitélio juncional como um colar circundando cada dente com aproximadamente $2 \mathrm{~mm}$ de dimensão coronoapical. Propuseram que sua espessura apical consiste somente de 1 ou 2 células sendo, que coronalmente possui 15-30 células na base do sulco gengival. Para os autores, subjacente ao sulco gengival é aproximadamente $0,15 \mathrm{~mm}$ mais largo e o turnover do epitélio juncional corresponde a 4-6 dias enquanto o do epitélio oral de 6-12 dias.
}

LINDHE $^{24}$ (1989) descreveu a formação e desenvolvimento do epitélio juncional da seguinte maneira: 
1) Quando o esmalte dentário alcança seu desenvolvimento completo, as células produtoras do esmalte (ameloblastos) sofrem redução em sua altura, produzem a lâmina basal e formam juntamente com as demais células externas do epitélio do órgão do esmalte o chamado epitélio reduzido do esmalte.A lâmina basal fica em contato direto com o esmalte; o contato entre esta lâmina e as células epiteliais é mantido por hemidesmossomos. O epitélio reduzido do esmalte circunda a coroa do dente a partir do momento em que o esmalte se torna mineralizado adequadamente até que comece a erupção dentária;

2) À medida que o dente em erupção se aproxima do epitélio bucal, as células da camada basal do epitélio bucal apresentam aumento da atividade mitótica, porém os ameloblastos primitivos não se dividem. O epitélio reduzido do esmalte é transformado gradativamente durante a erupção em epitélio juncional;

3) Quando o dente tiver adentrado a cavidade bucal, as células da camada externa do epitélio reduzido do esmalte e o epitélio bucal fundem-se na borda incisal do dente. Grandes porções imediatamente apicais à área incisal do esmalte são então recobertas pelo epitélio juncional contendo apenas poucas camadas de células. Todavia, a região cervical do esmalte está ainda coberta pelos ameloblastos e células do epitélio reduzido do esmalte; e

4) Durante as fases terminais da erupção dentária, todas as células do epitélio reduzido do esmalte são transformadas em epitélio juncional. Este epitélio transformado é contínuo com o epitélio bucal e participa da união da gengiva ao dente. 
RAMFJORD $^{40}$ et al. (1991) afirmaram que o epitélio juncional contém um número maior de espaços intercelulares e mais baixa densidade desmossômica do que no epitélio superficial, denotando somente poucas junções condensadas e mínimos filamentos citoplasmáticos. Todas estas características foram imputadas para explicar porque o epitélio é facilmente penetrável e separável mecanicamente. Além disso procurou-se salientar que a interface epitélio juncional-dente (lâmina basal interna) e a interface epitélio juncional-tecido conjuntivo (lâmina basal externa) são estruturalmente similares quando estudadas por microscopia eletrônica, manifestando-se a inserção por hemidesmossomas e uma lâmina basal. Em ambas as circunstâncias, os hemidesmossomas estão mais unidos à superfície do dente do que à junção epitélio-tecido conjuntivo.

LISTGARTEN $^{25}$ et al. (1991) compararam os tecidos periodontais ao redor de implantes dentais e dentes naturais. Como na dentição natural, verificaram que o epitélio juncional é conectado à superfície do implante por uma lâmina basal e hemidesmossomas, o que os levou a sugerirem que a relação do epitélio juncional com os implantes dentais é bem parecida àquela da dentição natural.

\subsubsection{INSERÇÃO CONJUNTIVA}

RAMFJORD $^{40}$ et al. (1991) descreveram o tecido conjuntivo gengival como denso e fibroso, com orientação funcional complexa desenvolvida gradualmente durante a erupção dentária, e que mais tarde é modificada por demandas funcionais; a orientação estrutural destes tecidos é bem adequada para suportar o stress físico da mastigação e deglutição. De acordo com os autores, em sua orientação estrutural, as fibras têm padrão entrelaçado e várias fibras não são nem mesmo inseridas à superfície do 
dente. A função das fibras é estabilizar a gengiva inserida ao processo alveolar e ao dente e, em menor menor extensão, estabilizar o dente ao osso. A disposição circunferencial das fibras (ligamento circular) mantém o epitélio juncional em estreito contato com o dente e ajuda a manter o epitélio selado ao dente, enquanto as fibras interdentais auxiliam na estabilização dos dentes. Propuseram a disposição das fibras nas seguintes direções:

1) do cemento para a gengiva livre (fibras gengivais livres);

2) do cemento para a ponta da papila interproximal (fibras papilares ou gengivais livres);

3) interproximalmente de dente a dente (fibras transeptais);

4) rodeando o dente completamente ou parcialmente de maneira anelar (fibras circulares ou semi circulares);

5) do cemento para a crista alveolar (fibras alvéolo-cristais);

6) da gengiva livre para a crista alveolar (fibras crestogengivais);

7) da lâmina basal da mucosa gengival livre e aderida para o processo alveolar (fibras do processo alveolar);

8) mais ou menos paralelas ao processo alveolar sem orientação funcional aparente; e

9) fibras dento gengivais dispostas radialmente transversas.

HASSEL $^{19}$ (1993) relatou que aproximadamente 60-65\% do tecido conjuntivo de uma gengiva saudável é ocupado por colágeno, com as fibrilas individuais altamente organizadas dentro de feixes discretos e facilmente discerníveis. Os outros elementos descritos foram os fibroblastos que incluem cerca de 5\%, outras células como macrófagos teciduais, 
leucócitos etc. $3 \%$, restando $35 \%$ do volume remanescente ocupado por elementos vasculares (sangue e linfa), nervos e substância fundamental amorfa. Esta foi considerada como constituída basicamente de várias glicoproteínas e proteoglicanas. As relações anatômicas das fibras de gengiva marginal foram tidas como tendo importante significação no comportamento das estruturas de sustentação em vários estados mórbidos, havendo grande grau de interdependência entre os vários segmentos da gengiva. Considerou que grande porção da estrutura fibrilar das gengivas marginal facial e lingual de um dente origina-se da superfície radicular ou da gengiva de um dente adjacente. Portanto, o estado da gengiva marginal de um dente dependeria em grande parte da saúde das estruturas de suporte do dente adjacente. Mencionou que a presença de doença na região do sulco gengival de um dente pode levar à ruptura das fibras transgengivais, intergengivais ou transeptais e portanto a capacidade funcional da gengiva marginal dos dentes vizinhos. O fibroblasto foi a célula predominante, compreendendo $65 \%$ da população celular total tomando por base o volume. Funcionalmente foi considerada a célula mais importante, pois produzem as substâncias do tecido conjuntivo incluindo colágeno, proteoglicanas e elastina e portanto desempenham papel importante na manutenção da integridade do tecido gengival. Quando observadas no microscópio eletrônico mostraram todas as características de células em ativo trabalho de síntese. Os mastócitos foram encontrados em grande número na gengiva humana normal. Geralmente localizados próximo aos vasos sangüíneos e caracterizados por apresentar grânulos contendo heparina, histamina e enzimas proteolíticas. Enfatizou que a degranulação destass substâncias é produzida com a lesão tecidual em certas condições patológicas, como na inflamação gengival aguda, e a descarga da heparina pode estar relacionada 
à perda óssea associada a doença periodontal inflamatória.Macrófagos e monócitos têm sido encontrados na gengiva normal não inflamada. Macrófagos possuem capacidade de produzir grandes quantidades de enzimas hidrolíticas, que desempenham uma função desintoxicante e de limpeza da gengiva normal. Se bem que leucócitos polimorfonucleares sejam vistos freqüentemente dentro dos vasos sangüíneos e dentro do epitélio juncional na gengiva humana clinicamente normal, raramente essas células se acham presentes na substância de tecidos conjuntivos não inflamados. Os leucócitos poderiam migrar de vasos sangüíneos do plexo gengival e penetrar rapidamente no epitélio juncional, possivelmente em resposta a substâncias liberadas da placa dentobacteriana ou da saliva.

Linfócitos e plasmócitos também foram encontrados nos

tecidos conjuntivos gengivais humanos que não apresentam outras manifestações de alteração patológica, com predominância de plasmócitos em torno dos vasos sangüíneos.(SCHROEDER ${ }^{44}$, 1982; SCHLUGER $^{43}$, 1991)

\subsubsection{PERIODONTO DE SUSTENTAÇÃO}

\subsubsection{OSSO ALVEOLAR}

O processo alveolar é a extensão óssea da mandíbula e da maxila envolvendo as raízes dos dentes. Dentro do processo alveolar, RAMFJORD $^{40}$ et al (1991) consideraram o osso alveolar próprio com uma placa fina de osso lamelado, que providencia o acoplamento e a inserção das fibras que mantêm os dentes em suspensão. 
RATEITSCHAK $^{41}$ et al. (1991) relataram que os processos alveolares são estruturas dente-dependentes desenvolvidas com a formação e erupção dos dentes e que se atrofiam, em grande parte, com a perda dos mesmos. Discriminaram três estruturas do processo alveolar:

1) Osso alveolar próprio-Lâmina dura;

2) Osso esponjoso;

3) Osso compacto ou cortical. .

Propuseram que o osso imediatamente adjacente à superfície da raiz, no qual as fibras de Sharpey do ligamento periodontal se inserem, tem sido denominado osso alveolar próprio para contrastar com o osso cortical externo, que compreende as lâminas corticais periféricas do osso esponjoso.

O osso alveolar próprio (lâmina cribriforme) seria perfurado para permitir comunicação dos nervos e vasos sangüíneos entre o ligamento periodontal e os espaços medulares. Três tipos de células estão associadas com o osso: osteoblastos, osteócitos e osteoclastos.

\subsubsection{LIGAMENTO PERIODONTAL}

\section{HASSEL $^{19}$ (1993) descreveu que o ligamento periodontal} ocupa um espaço de 0,15 a $0,38 \mathrm{~mm}$, situado entre o cemento que cobre a raiz e o osso alveolar próprio. Considerou-se que este espaço é ocupado por um complexo tecido conjuntivo que suporta e mantém cada dente no seu alvéolo, contendo células, vasos sangüíneos e linfáticos, substância fundamental amorfa e feixes de fibras colágenas.

WILSON $^{56}$ (1996) relatou que as fibras principais do ligamento periodontal podem ser divididas em seis grupos com funções presumidas baseado em sua localização e inserção: 
1) Crista alveolar: retém o dente no seu alvéolo e opõem-se às forças laterais;

2) Oblíqua: opõem-se às forças axiais;

3) Transeptal: mantêm o contato proximal dos dentes;

4) Horizontal : opõem-se às forças laterais;

5) Interradicular: previnem a extrusão e inclinação;

6) Apical: Resistem às forças de extrusão, protegem vasos e nervos que suprem o dente. Considerou o fibroblasto como o componente celular principal do ligamento periodontal é o fibroblasto, tendo como principal função a síntese e degradação de colágeno. Referiu-se a uma função do periodonto, que seria a de agir como receptor sensorial indispensável para o posicionamento adequado da mandíbula contra a maxila durante a função normal.

\subsubsection{CEMENTO}

SELVIG $^{45}$ (1965) relatou o cemento radicular como um tecido calcificado especializado que recobre as superfícies radiculares dos dentes e, ocasionalmente, pequenas porções das coroas dos dentes, com muitas características em comum com o tecido ósseo. Todavia, o cemento foi relatado não conter vasos sanguíneos e linfáticos, não ter inervação, não sofrer remodelação e reabsorção fisiológicas, porém caracterizado pela deposição contínua ao longo da vida. Como outros tecidos mineralizados, foi citado como constituído de fibras colágenas embutidas em uma matriz orgânica. Sua porção mineral é formada principalmente por cristais de hidroxiapatita, sendo responsável por aproximadamente $65 \%$ de seu peso; um pouco mais que o osso (60\%). Foram observadas várias funções 
desempenhadas como: inserção das fibras do ligamento periodontal à raiz e contribuição para o processo de reparo após danos à superfície radicular. Dois tipos diferentes de cemento foram reconhecidos:

1) Cemento primário ou cemento acelular, que é formado em associação com a formação da raiz e a erupção do dente; e

2) Cemento secundário ou cemento celular, que foi relatado se formar após a erupção do dente e, também, em resposta a demandas funcionais. Entretanto, áreas da superfície radicular poderiam ser alternadas com cemento acelular e cemento celular.

A inserção das fibras do ligamento periodontal ao cemento foi observada serem mantidas por uma deposição contínua e muito lenta de novo cemento ancorando as novas fibras.

\subsection{AS DISTÂNCIAS BIOLÓGICAS}

GARGIULO $^{13}$ et al. (1961) descreveram as dimensões e relações da junção dento-gengival em autópsia de espécimes humanos. Sua pesquisa estabeleceu que há um relacionamento dimensional proporcional dentro do espaço de $\pm 2,73 \mathrm{~mm}$, compreendido no nível da crista do osso alveolar até o nível da margem gengival e abrangendo a inserção conjuntiva, epitélio juncional e epitélio do sulco. Em seu estudo, um total de 325 medidas foram tomadas (aferidas) de espécimes clinicamente normais. Os autores notaram grande consistência na dimensão de vários componentes:

1) a profundidade do sulco foi de $0,69 \mathrm{~mm}$;

2) o epitélio juncional abrangeu $0,97 \mathrm{~mm}$;

3) a inserção conjuntiva mostrou em média 1,07 mm. 
A descoberta mais consistente foi observada na inserção conjuntiva, cuja medida média era de $1,07 \mathrm{~mm}$ com variação de 1,06 à $1,08 \mathrm{~mm}$, enquanto que a medida média do epitélio juncional foi de $0,97 \mathrm{~mm}$ variando de 0,71 à 1,35mm. A dimensão combinada entre a inserção conjuntiva e o epitélio juncional, que foi em média de $2,04 \mathrm{~mm}$, tem sido considerada como “distância biológica”. (WAAL; CASTELLUCCI $\left.{ }^{54}, 1993\right)$.

ALLISON $^{7}$ (1992) descreveu que a dimensão global de 2,04 mm concorda com o mínimo de distância requerida entre a margem de uma restauração à crista óssea alveolar, para permitir o desenvolvimento de um anexo de tecido normal. Isto porém colocaria a margem restaurativa exatamente na base do sulco gengival. Considerou uma aproximação mais realista prover pelo menos $3 \mathrm{~mm}$ de tecido mole da crista óssea à estrutura de dente sadia significando assim $2 \mathrm{~mm}$ para a distância biológica e pelo menos $1 \mathrm{~mm}$ para o sulco gengival. Assim, quando restaurações, cáries, reabsorção ou fratura subgengival que invadem mais de $3 \mathrm{~mm}$ da margem gengival à crista óssea, as distâncias biológicas foram violadas, ocasionando desta maneira complicações como inflamação gengival, sangramento, perda irreversível de inserção e reabsorção óssea com formação de bolsas periodontais.

Saliente-se, entretanto, que, segundo WAAL; CASTELLUCCI $^{54}$ (1993), alterações periodontais se manifestam quando há invasão do que chamam distâncias biológicas correspondendo às áreas do epitélio juncional e da inserção conjuntiva. Portanto, mais precisamente quaisquer tipos de envolvimentos ou abordagens que se estendam além da base do sulco gengival devem ser considerados como potencialmente danosos para o periodonto, como corrobado por SCHLUGER ${ }^{43}$ et. al. 
NEVINS $^{35}$ et al. (1998) descreveu que a dimensão sadia do periodonto da crista óssea a margem gengival é a medida mínima necessária para intervenção protética e não resultará em recessão gengival a menos que ocorra um rompimento das fibras supracristais. Isto significa que, sendo o epitélio sulcular e o epitélio juncional avascular, o sangramento é uma indicação que o instrumento rotatório penetrou no tecido gengival e destruiu a conexão das fibras de Sharpey. Isto resultaria em proliferação apical de epitélio juncional e desviaria o mecanismo que preveniria recessão gengival.

Margens restaurativas subgengivais foram associadas com maior acúmulo de placa, inflamação e irritação mecânica. A alternativa clínica seria uma integração entre periodontia e odontologia estética. A definição clínica de preparo intrasulcular, seria a colocação da restauração no espaço entre o dente e o epitélio sulcular sem infringir o epitélio juncional. Ao contrário de subgengival, que freqüentemente é definida como desaparecimento do bordo protético dentro da margem gengival. ${ }^{29,50,54}$

Entretanto, é de se considerar que, acolhendo a proposta de MAYNARD; WILSON ${ }^{32}$ (1979) incluindo a gengiva ceratinizada como parte das distâncias biológicas, PASSANEZI ${ }^{39}$ et. al consideraram que o "creeping attachment" nada mais é do que a reconstrução das distâncias biológicas voltadas contra os dentes por influência da quantidade de gengiva ceratinizada. Propuseram, assim, que a quantidade de tecido mole sobre a a crista óssea alveolar é fator importante na proteção da integridade da própria crista óssea. Essas observações foram fundamentadas na análise de diversos trabalhos, que estudaram o comportamento periodontal marginal em função de variações na quantidade de gengiva ceratinizada. Tais considerações 
refletem, pois, a importância da análise do volume de tecidos moles na área supra-alveolar.

\subsection{A SONDA PERIODONTAL}

A sonda periodontal é o instrumento de diagnóstico mais largamente utilizado para determinar a presença e severidade de doença periodontal. Durante a destruição periodontal, ocorre a perda de inserção conjuntiva de fibras com proliferação e migração do epitélio juncional além da redução da altura óssea. Uma das características deste processo patológico é a transformação do sulco gengival em bolsa periodontal por aumento patológico da profundidade do mesmo. Portanto, bolsa periodontal pode ser aceita como um conceito quantitativo da doença e a sua avaliação rápida através de medidas de sondagem é necessária para diagnóstico e pesquisas epidemiológicas.

Para investigar a influência do tipo de calibração da sonda e da sua leitura na confiabilidade da mensurações, VAN DER VELDEN $^{53}$ (1978) utilizou a sonda Merrit-B (Hu-Friedy), a qual já era utilizada no seu departamento e sonda possuia marcações de 1 a $10 \mathrm{~mm}$. Observou-se a diferença entre o tipo de calibração onde não estão marcados os milímetros 4 e 6 e a calibração na qual os mesmos são adicionados. A avaliação da leitura dos tipos diferentes de calibração foi realizada in vitro utilizando-se 32 cubas cilíndricas com um orifício central de $1 \mathrm{~mm}$ de diâmetro e profundidade variando de 0.25 a $8 \mathrm{~mm}$, com incrementos de $0.25 \mathrm{~mm}$. Cada examinador fez duas medições com intervalos de 3 dias. As profundidades de sondagem de $1 \mathrm{a} 8 \mathrm{~mm} \pm 0.25 \mathrm{~mm}$ geralmente estiveram corretas em $90 \%$ das leituras. O mais importante achado foi que as 
profundidades de sondagem de $4 \pm 0.25 \mathrm{~mm}$ e $6 \pm 0.25 \mathrm{~mm}$ só foram lidas corretamente em $60 \%$ dos casos, comparadas a cerca de $90 \%$ em todas as outras medições, quando a sonda sem os milímetros 4 e 6 foi utilizada. Esta diferença desapareceu quando as marcações dos milímetros 4 e 6 foram adicionados. Em 95\% dos casos houveram leituras incorretas ao nível 4 e 6 estiveram abaixo do valor real, significando subestimação das medições.

Sondas periodontais foram coletadas aleatoriamente de 5 periodontistas por $\operatorname{OSBORN}^{37}$ (1990) para avaliar a precisão das suas marcações em milímetros. Foram coletadas 129 sondas (Williams, Goldman-Fox e Michigan), as quais foram agrupadas por tipo e fabricante. Os resultados demonstraram que a maioria das marcações não eram precisas. Um total de 387 medições foram feitas, das quais 130 imprecisas. A precisão estava relacionada a época de fabricação das sondas, havendo por exemplo, diferença entre as marcações de sondas mais antigas e recentes fabricadas pela Hu-Friedy . Segundo o autor, sondas periodontais de diferentes fabricantes e fabricadas em épocas diferentes mostraram variação ampla na precisão das marcações dos milímetros. Portanto, o acúmulo de sondas periodontais com marcações inconsistentes podem ocorrer, o que poderia afetar planos de tratamento e decisões feitas pelo clínico. Naturalmente, para tanto, os profissionais deveriam se basear essencialmente nessas medições. Ainda segundo o autor, o uso rotineiro da sonda periodontal foi incentivado ser o instrumento diagnóstico de maior validade disponível para os exames periodontais. Vários tipos de sonda com diferentes desenhos e calibrações foram descritas, salientando que devem permitir sua inserção no sulco gengival ou bolsa periodontal com mínimo desconforto e trauma aos tecidos. Este instrumento seria adequado para determinar a saúde e arquitetura do 
periodonto, detectando defeitos ósseos consequentes da doença periodontal e constituindo base importante para seu diagnóstico, de acordo com seu uso correto. Dois métodos de sondagem foram descritos: 1) a introdução da sonda no sulco ou bolsa, seguindo a "inserção epitelial" o que refletiria a topografia óssea imediatamente apical de forma mais ou menos consistente; 2) e a sondagem que atravessa tecido mole até atingir crista óssea, o que seria uma avaliação mais definitiva da arquitetura do osso e relacionamento com o tecido mole, exigindo anestesia. A observação cuidadosa da informação obtida pela sondagem associada ao método radiográfico permitiria ao clínico uma seleção de tratamento mais adequada.

\section{HANCOCK; WIRTHLIN ${ }^{18}$ (1981) propuseram estudo}

para determinar o nível de inserção em macacos Rhesus com gengiva normal, gengivite e periodontite (experimentalmente induzidas) por mensurações através de sondas periodontais. Sondas de Williams foram avaliadas e duas escolhidas de acordo com a melhor precisão para servirem de modelos. As sondas foram moldadas com material de impressão à base de borracha e confeccionadas réplicas em acrílico recobertas com ouro (diâmetro na ponta de 0.47 e $0.48 \mathrm{~mm}$ e ao nível da marcação de $10 \mathrm{~mm}, 0.78$ e $0.79 \mathrm{~mm})$. Testes em laboratório determinaram que as réplicas acrílicas curvam-se a uma força de $25 \mathrm{~g}$ e quebram-se a uma força de $30 \mathrm{~g}$, sugerindo que a força de inserção das sondas ficou entre 25 e $30 \mathrm{~g}$. As sondas foram introduzidas nos sulcos/bolsas gengivais das faces vestibulares e depois fixadas com cimento cianocrilato; os dentes foram removidos em bloco (dente, sonda, gengiva e crista óssea vestibulares) e processados os cortes para avaliação histológica e histométrica. Nas áreas com periodontite, a sonda parou aproximadamente ao nível do tecido conjuntivo de inserção. Foi 
concluído que a sonda pararia ao nível de uma junção dentogengival saudável, não estimando se epitélio ou tecido conjuntivo. Na saúde gengival o tecido conjuntivo de suporte estaria ao nivel da base do sulco gengival e na presença de doença estaria ao nível da terminação apical do epitélio juncional.

SPRAY $^{48}$ et al.(1978) apresentaram estudo histológico (exame micoscópico com avaliação histométrica) para determinar a posição da extremidade das sondas periodontais e a resposta dos tecidos locais à sua presença. Lâminas de sondas periodontais Michigan "O" foram introduzidas no sulco gengival de 15 dentes, que haviam sido indicados para extração, sobre pressão padronizada (entre 15 a $20 \mathrm{~g}$ ). Com as sondas mantidas no local, através de tubos ortodônticos e resina composta, os espécimes foram obtidos por secções em bloco, processados, corados e avaliados. Nos cortes histológicos foram observadas a condensação e compressão de feixes colágenos apicais à sonda, como se fosse uma "rede", aparentemente limitando seu movimento apical. Em 6 dos 8 espécimes avaliados, a sonda afastou o epitélio sulcular e penetrou no epitélio juncional, atingindo o tecido conjuntivo $(0.27 \pm 0.15 \mathrm{~mm}$ apical ao seu limite coronal). Nos outros 2 espécimes, a sonda penetrou o epitélio juncional com sua extremidade ficando coronal à base do mesmo $(0.21 \pm 0.02 \mathrm{~mm})$; aparentemente seu movimento foi parado pelo tecido conjuntivo e não se observou tecido epitelial entre este e a sonda. A condensação das fibras colágenas ofereceu resistência ao movimento da sonda colocada com força padronizada. $\mathrm{O}$ epitélio juncional ofereceu pequena resistência à sonda metálica. Daí a sugestão de que o estado de saúde das fibras conjuntivas influenciariam as mensurações das bolsas periodontais, sendo mais importantes na limitação 
do movimento da sonda do que o epitélio juncional. Segundo PASSANEZI $^{1 *}$ (2001) isso ilustraria que a função primária do epitélio juncional é atuar como elemento de selamento entre o meio externo e interno e não como elemento de adesão do tecido gengival do dente.

JEFFCOAT $^{20}$ (1986) comparou sondagens manual e realizada com sonda de pressão controlada. Os pacientes eram portadores de periodontite de moderada a profunda (bolsas de 2 a $15 \mathrm{~mm}$ ) sendo as mensurações feitas em três tempos diferentes (antes de qualquer tipo de instrumentação subgengival, após 4 semanas de raspagem e polimento corono-radicular e 10 semanas após terapia cirúrgica para instrumentação radicular). Dois examinadores experientes foram envolvidos neste trabalho: um designado para a realização da sondagem manual sem modificaçcão da sua técnica (avaliação prévia revelou força de sondagem de aproximadamente $32 \mathrm{~g}$, relativamente constante, em sulcos posteriores, vestibulares e saudáveis) e o outro treinado para trabalhar com uma sonda de pressão controlada (50 g), utilizando-se ponta idêntica à da sondagem manual $(0.35 \mathrm{~mm}$ de diâmetro, com faixas coloridas de $3 \mathrm{~mm}$ e sulcos confeccionados a cada $1 \mathrm{~mm}$ ). Os exames foram feitos na mesma sessão, com com três horas de intervalo entre os métodos. Observou-se que as profundidades de sondagens obtidas neste estudo foram reduzidas após a realização da terapia periodontal, em ambas técnicas de sondagem. As profundidades de sondagem com a sonda de pressão controlada foram significantemente maiores do que as obtidas com a sondagem manual nas faces livres dos dentes independente da fase de terapia. As mensurações obtidas pela técnica manual foram maiores nos aspectos distais posteriores,

\footnotetext{
${ }^{1}$ Comunicação pessoal
} 
particularmente regiões disto-linguais, quando não receberam terapia cirúrgica. A porcentagem de similaridade entre as mensurações $( \pm 1 \mathrm{~mm})$ obtidas pelos dois métodos diminuiu com o aumento da profundidade de sondagem medida, indiferentemente da localização de sítio, estágio de terapia e região da boca. Com isto, concluiu-se que a sondagem com pressão controlada pode ser um método mais objetivo para o monitoramento da condição periodontal nos estudos longitudinais.

$$
\text { MAGNUSSON; LISTGARTEN }{ }^{31} \text { (1980) avaliaram a }
$$

sondagem periodontal em dentes que receberam tratamento (raspagem e alisamento radicular, bochechos de clorexidina durante 1 mês) e dentes que não receberam tratamento. $\mathrm{O}$ estudo foi realizado em humanos com grau de doença periodontal variado em dentes com indicação para extração (periodontal, endodôntica e por cárie) e as sondagens executadas por um único examinador. Foram feitas marcações no dente ao nível da margem gengival estendendo-se até a dentina e utilizadas tiras de metal para avaliar o nível de inserção. O comprimento da tira inserida foi medido e transferido para o dente após sua extração, com confecção da marca correspondente. Os dentes foram processados e realizados cortes histológicos para as mensurações histométricas. No grupo que recebeu tratamento, as medições clínicas foram feitas da mesma forma antes das raspagem e repetidas após 1 mês, quando os dentes foram extraídos para as avaliações histológicas. Os dados claramente demonstraram que o tratamento de dentes com bolsas periodontais $\geq 4 \mathrm{~mm}$ resultou, após um mês, em maior resistência à sondagem do que antes do tratamento. Nas superfícies tratadas a tira metálica terminou dentro do epitélio juncional, coronal ao tecido conjuntivo de inserção em 7 das 11 superfícies (média de $0.31 \mathrm{~mm}$ coronal ao tecido 
conjuntivo), ao passo que nos dentes não tratados, em 6 das 18 superfícies situou-se apical ao tecido conjuntivo de inserção (média de $0.29 \mathrm{~mm}$. Para bolsas $<4 \mathrm{~mm}$, a sonda penetrou próximo ao nível mais coronal da inserção do tecido conjuntivo em ambas superfícies tratadas e não tratadas sem qualquer efeito devido ao tratamento. Logo, nas bolsas relativamente rasas, as mensurações clínicas tenderam a registrar a localização mais coronal do nível do tecido conjuntivo e nas bolsas mais profundas as tiras tenderam a penetrar no tecido em graus variados, com o tratamento mostrando menor número de casos com penetração no tecido conjuntivo.

Pode-se, portanto, observar que a variabilidade de resultados como o uso de sondas não dá margem a melhor definição dos parâmetros clínicos mensuráveis do periodonto marginal.

\subsection{AVALIAÇÃO DA INFLAMAÇÃO NOS TECIDOS PERIODONTAIS}

Um índice para o registro de depósitos de placas (Índice de Placa) em escala de 0 a 3 foi apresentado por SILNESS; LÖE ${ }^{46}$ (1964), segundo o qual a ausência de depósitos de placas receberia grau 0, a visualização da placa após sua remoção como o uso da sonda periodontal na margem gengival, registrada como 1, a placa clinicamente visível, 2 e a placa abundante, grau 3.

Um método paralelo de avaliação denominado Índice Gengival foi descrito por $\mathrm{LÖE}^{27}$ (1967) como tentativa de determinação das condições gengivais marginais, para também serem utilizadas em estudos epidemiológicos. Segundo o autor, neste sistema a ausência total de sinais visuais de inflamação na unidade gengival seria registrada como 0 , ao passo 
que uma ligeira alteração na cor e na textura seria registrada como 1. A inflamação visual e a tendência ao sangramento da margem após a verificação com a sonda periodontal seriam registradas como 2 , ao passo que a inflamação patente com tendência ao sangramento espontâneo conseqüentemente teriam escore registrado como 3. Variantes simplificadas dos Índices Gengival e de Placa de AINAMO; BAY ${ }^{3}$ (1975) têm sido bastante utilizadas, avaliando-se a presença/ausência de inflamação ou placa respectivamente em um padrão binomial (contagem dicotômica). Neste sistema, os autores classificaram sangramento da margem gengival e placa visível como grau "1", enquanto a ausência de sangramento e nenhuma placa visível, “0”.

MUHLEMANN; SON ${ }^{33}$, (1971) criaram um meio de avaliar a presença de inflamação sub-gengival e a denominaram Índice de Sangramento Sulcular (sangramento após a sondagem até a base do sulco gengival). Neste registro dicotômico, os autores determinaram que "0" seria ausência clínica de sangramento e "1" seria classificado quando o grau de sangramento fosse visível em 15 segundos após a sondagem.

Segundo LINDHE ${ }^{22}$, a contagem dicotômica (presença/ausência de sangramento com a sondagem até a base do sulco - que foi utilizado neste trabalho) tem substituído o uso do Índice Gengival de SILNESS; LÖE ${ }^{22}$ nos estudos epidemiológicos. 
3 PROPOSIÇÃO 


\section{PROPOSIÇÃO}

Este trabalho tem a finalidade de:

1) Analisar a espessura da margem gengival determinada pelo Sonar de Espessura de Tecidos Moles (SETM);

2) Correlacionar esta espessura gengival com outros parâmetros clínicos já conhecidos e analisados como:

a) Profundidade de sondagem clínica com a sonda periodontal manual;

b) Espessura da margem óssea;

c) Largura da mucosa ceratinizada

d) Índice de sangramento gengival à sondagem (Índice de Sangramento Gengival Dicotômico - ISG) proposto por MUHLEMANN; SON (1971);

e) Distância da margem gengival ao nível ósseo 
4 MATERIAL E MÉTODOS 


\section{MATERIAL E MÉTODOS}

\subsection{SELEÇÃO DE PACIENTES}

Para o desenvolvimento da pesquisa foram pré-selecionados pacientes que se submeteriam a tratamento de fixação de implantes ósseointegrados. Este procedimento clínico apresenta, para a garantia de seu alto índice de previsibilidade, protocolo cirúrgico extremamente rigoroso, que contra-indica a fixação de implantes em áreas adjacentes à elementos dentais com doença periodontal ativa, perda de inserção e bolsas periodontais. Dessa forma, os dentes selecionados para esta pesquisa apresentavam-se clinicamente saudáveis.

Através de rigoroso exame clínico, os pacientes foram instruídos sobre a natureza da pesquisa a ser desenvolvida paralelamente à fixação dos implantes ósseo-integrados, estando cientes sobre a forma e motivo da coleta de dados. Um documento de permissão para esta coleta de dados anexo à ficha clínica foi devidamente preenchido, e assinado pelo paciente e incluído no trabalho. Os dados não influíram na qualidade final ou na morbidade pós-operatória, o que qualificou a pesquisa dentro dos critérios éticos de tratamento odontológico estabelecidos pelo Comitê de Ética da Faculdade de Odontologia da Universidade de São Paulo.

Foram realizados por um único operador, em áreas vizinhas a fixação de implantes osseointegrados, 396 medidas em 66 dentes adjacentes de 33 pacientes sem distinção de raça ou sexo, com idade compreendida entre 15 e 68 anos, 13 do sexo masculino e 19 do sexo feminino, 4 fumantes e 29 não fumantes (Tabela 1). Realizou-se previamente sondagem manual com uma sonda periodontal modelo "Michigan $\varnothing "$ (Hu-Friedy) nos sítios 
adjacentes envolvidos em cirurgias de implantodontia. Neste exame também foram confirmadas as seguintes características clínicas gerais:

1) ausência de alterações periodontais aparentes;

2) ausência de alterações sistêmicas;

3) pacientes não gestantes;

4) pacientes que não fizeram uso de medicamentos controlados nos últimos 6 meses. 


\begin{tabular}{|c|c|c|c|c|c|}
\hline PACIENTE & IDADE & MASCULINO & FEMININO & FUMANTE & $\begin{array}{c}\text { NÃO } \\
\text { FUMANTE }\end{array}$ \\
\hline 1 & 37 & & $\mathrm{X}$ & & $\mathrm{X}$ \\
\hline 2 & 45 & & $\mathrm{X}$ & & $\mathrm{X}$ \\
\hline 3 & 47 & $\mathrm{X}$ & & & $\mathrm{X}$ \\
\hline 4 & 42 & $\mathrm{X}$ & & & $\mathrm{X}$ \\
\hline 5 & 50 & $\mathrm{X}$ & & & $\mathrm{X}$ \\
\hline 6 & 41 & $\mathrm{X}$ & & & $\mathrm{X}$ \\
\hline 7 & 34 & $\mathrm{X}$ & & & $\mathrm{X}$ \\
\hline 8 & 43 & $\mathrm{X}$ & & & $\mathrm{X}$ \\
\hline 9 & 60 & $\mathrm{X}$ & & & $\mathrm{X}$ \\
\hline 10 & 68 & $\mathrm{X}$ & & & $\mathrm{X}$ \\
\hline 11 & 21 & & $\mathrm{X}$ & & $\mathrm{X}$ \\
\hline 12 & 35 & & $\mathrm{X}$ & & $\mathrm{X}$ \\
\hline 13 & 39 & & $\mathrm{X}$ & & $\mathrm{X}$ \\
\hline 14 & 40 & & $\mathrm{X}$ & & $\mathrm{X}$ \\
\hline 15 & 48 & & $\mathrm{X}$ & & $\mathrm{X}$ \\
\hline 16 & 63 & & $\mathrm{X}$ & & $\mathrm{X}$ \\
\hline 17 & 56 & & $\mathrm{X}$ & & $\mathrm{X}$ \\
\hline 18 & 50 & & $\mathrm{X}$ & $\mathrm{X}$ & \\
\hline 19 & 39 & & $\mathrm{X}$ & & $\mathrm{X}$ \\
\hline 20 & 42 & & $\mathrm{X}$ & & $\mathrm{X}$ \\
\hline 21 & 37 & & $\mathrm{X}$ & & $\mathrm{X}$ \\
\hline 22 & 58 & $\mathrm{X}$ & & $\mathrm{X}$ & \\
\hline 23 & 19 & $\mathrm{X}$ & & & $\mathrm{X}$ \\
\hline 24 & 38 & $\mathrm{X}$ & & & $\mathrm{X}$ \\
\hline 25 & 53 & $\mathrm{X}$ & & $X$ & \\
\hline 26 & 33 & & $\mathrm{X}$ & & $\mathrm{X}$ \\
\hline 27 & 43 & & $\mathrm{X}$ & & $\mathrm{X}$ \\
\hline 28 & 33 & & $\mathrm{X}$ & & $\mathrm{X}$ \\
\hline 29 & 52 & & $\mathrm{X}$ & & $\mathrm{X}$ \\
\hline 30 & 48 & $\mathrm{X}$ & & $\mathrm{X}$ & \\
\hline 31 & 42 & & $\mathrm{X}$ & & $\mathrm{X}$ \\
\hline 32 & 46 & & $\mathrm{X}$ & & $\mathrm{X}$ \\
\hline 33 & 15 & $\mathrm{X}$ & & & $\mathrm{X}$ \\
\hline TOTAIS & $\begin{array}{c}42,9 \\
\text { (idade média) }\end{array}$ & 14 & 19 & 4 & 29 \\
\hline
\end{tabular}

TABELA 1 - Perfil dos pacientes 


\subsection{PADRONIZAÇÃO DA AMOSTRA (Baseline)}

Os 32 pacientes (Tabela 1) receberam instruções de higiene e fisioterapia oral e foram submetidos à raspagem supra e subgengival com aparelho ultrasônico do tipo Cavitron 3000 da Dentsply, curetas manuais de Gracey (Hu-Friedy) para alisamento radicular, polimento coronário e remoção de todos os possíveis fatores etiológicos secundários locais como restaurações mal adaptadas, oclusão traumática e outros, com finalidade de padronização da amostra (baseline).

\subsection{COLETA DE DADOS}

As distâncias biológicas e suas magnitudes médias descritas por GARGIULO et al. ${ }^{13}$ e citadas por vários autores ${ }^{4,8,9,17,19,26,28,32}$ em trabalhos clássicos vêm sendo utilizadas como referência para trabalhos clínicos com a finalidade da preservação e/ou reconstituição da integridade da homeostasia do periodonto marginal. Métodos de análise não invasivos podem ser utilizados para agregar-se ao arsenal de recursos utilizados clinicamente. Com a finalidade de se realizar uma análise comparativa entre as medidas das distâncias biológicas dos componentes dos periodontos de proteção e sustentação, os seguintes dados foram coletados: 


\subsubsection{ESPESSURA DA MUCOSA GENGIVAL MARGINAL (MG - e)}

Para as medições volumétricas dos tecidos moles foi utilizado o equipamento SDM (Schleimhautdicken-Mebgerät - Aparelho de Medição da Espessura da Mucosa*) que apresenta as seguintes características técnicas:

Cabeça manométrica

- Frequência: 5MHZ

- Peso: $19 \mathrm{~g}$

- Central de processamento

- Margem de medição: 0,5 a 8,0mm

- Velocidade sônica de medição: 1.518 m/s

- Exatidão: 0,1mm

- Visor: LCD 12,7mm

- Dimensões: 80mm X 145mm X 40mm

- Peso: 400g

Para esta mensuração utilizou-se o aparelho SDM (Schleimhautdicken-Mebgerät - Aparelho de Medição da Espessura da Mucosa) que serve do princípio do sistema eco-impulso, através do registro do tempo de propagação do ultra-som (Figura 1).

O aparelho apresenta uma cabeça manométrica contendo um cristal piezo-elétrico, que emite impulsos de ultra-som passando pelo tecido mole e alcançando a superfície dental ou óssea, de onde é refletido de volta e captado pela cabeça manométrica (Figura 2). Cada um destes ciclos de

\footnotetext{
* Krupp Medizintechnik GmbH - Alemanha
} 
medição ocupa 1m/s. A grande quantidade de medições individuais é permanentemente verificada de forma eletrônica e multiplicada pela velocidade sônica no tecido de $1520 \mathrm{~m} / \mathrm{s}$. O produto deste cálculo representa a espessura exata da mucosa e pode ser visto diretamente no aparelho.

Através de uma combinação especial de materiais e devido à diminuição do tamanho do cristal piezo-elétrico, o tamanho da cabeça manométrica foi minimizado pelo fabricante de forma a permitir medições em toda a área do prolongamento alveolar, assim como nas falhas de dentes (Figura 3). A margem de medição situa-se entre 0,5 e $8 \mathrm{~mm}$, tendo o valor indicado uma exatidão de até $0,1 \mathrm{~mm}$.

Depois de ligado o aparelho, este efetua primeiramente um teste de funcionamento com respectiva calibragem. Passado 1 segundo, o aparelho encontra-se pronto para efetuar as medições. Em casos de falhas no sistema, como por exemplo, má ligação à corrente , baixa carga de bateria ou cabeça manométrica com detritos ou sujeira, estas falhas são indicadas no visor através de símbolos .

Repetidamente e para efeitos de interconexão, a superfície frontal da cabeça manométrica é umedecida com um pouco de água ou saliva do paciente e colocada de forma plana no local pretendido na boca do paciente. Neste caso específico, o local de eleição é a gengiva marginal, posicionando a cabeça de modo que sua borda fique coincidente com a margem gengival livre (Figuras 4, 5 e 6). Isto não pode ser feito com demasiada pressão, caso contrário o valor medido será baixo demais. Logo que o aparelho inicia a medição, é emitido um sinal sonoro que é interrompido após cessar o contato com a mucosa, ou quando a cabeça manométrica é inclinada. Para obter valores de medição facilmente 
reproduzíveis, o contato entre a cabeça manométrica e o tecido deve ser mantido durante 2-3 segundos, quando o sinal sonoro estiver ativo (Figuras 5 e 6$)$. 


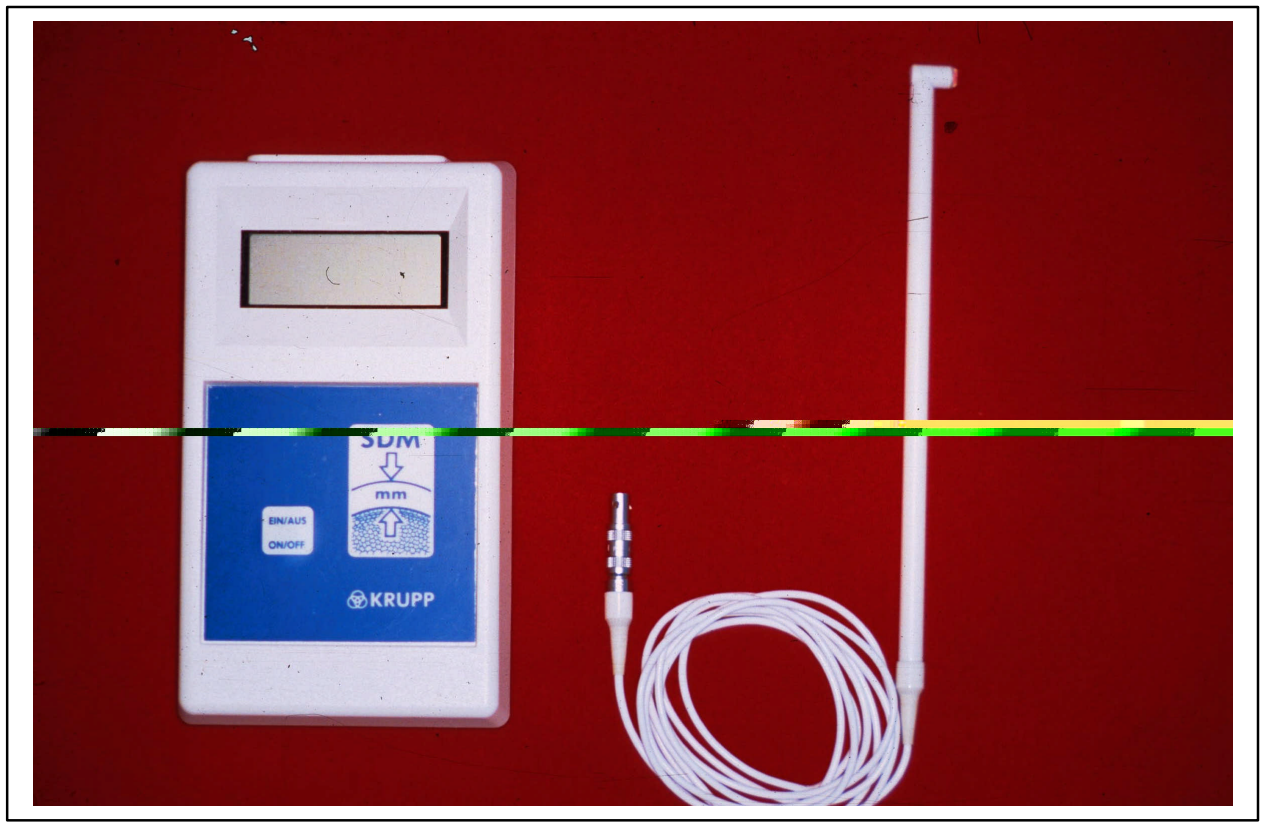

FIGURA 1 - O aparelho SDM para mensuração ultra-sônica de espessura de tecidos moles

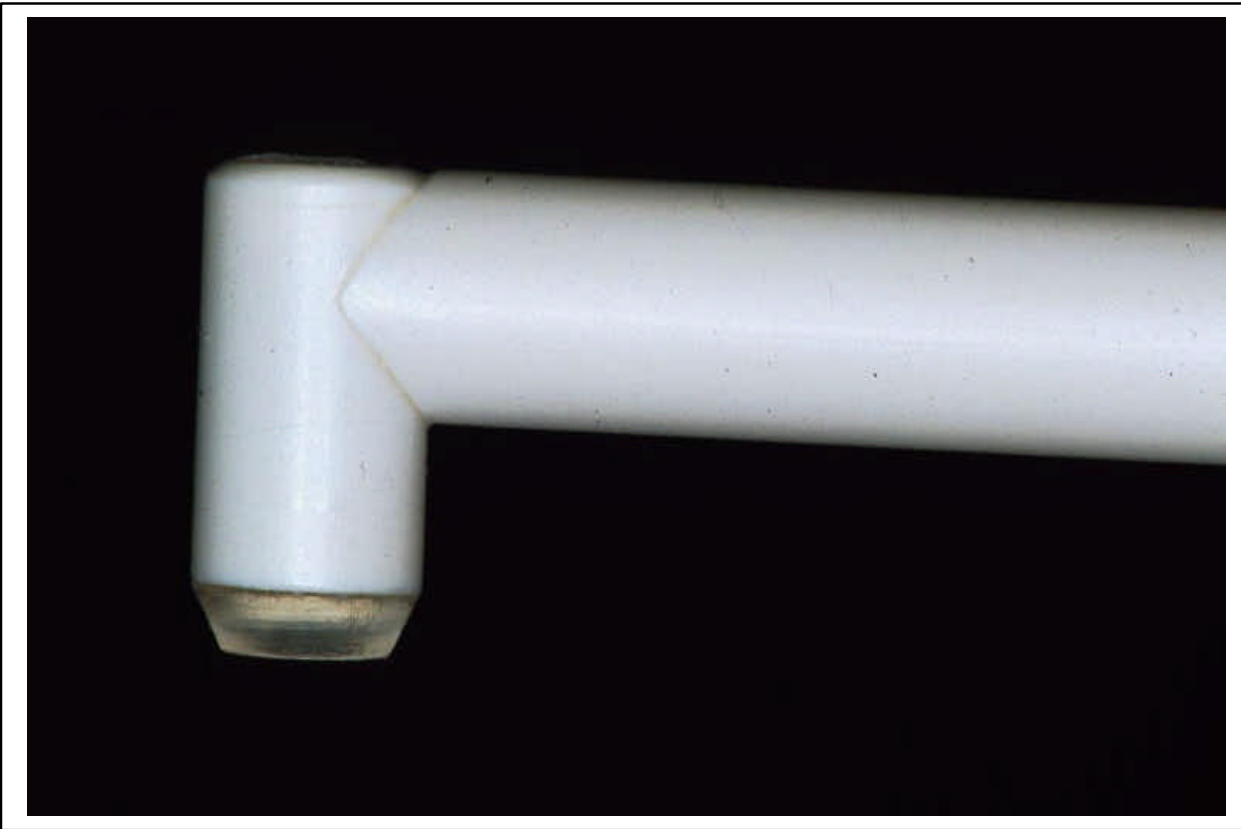

FIGURA 2 - Cabeça manométrica com cristal piezo-elétrico acoplado 
Material e Métodos - 44

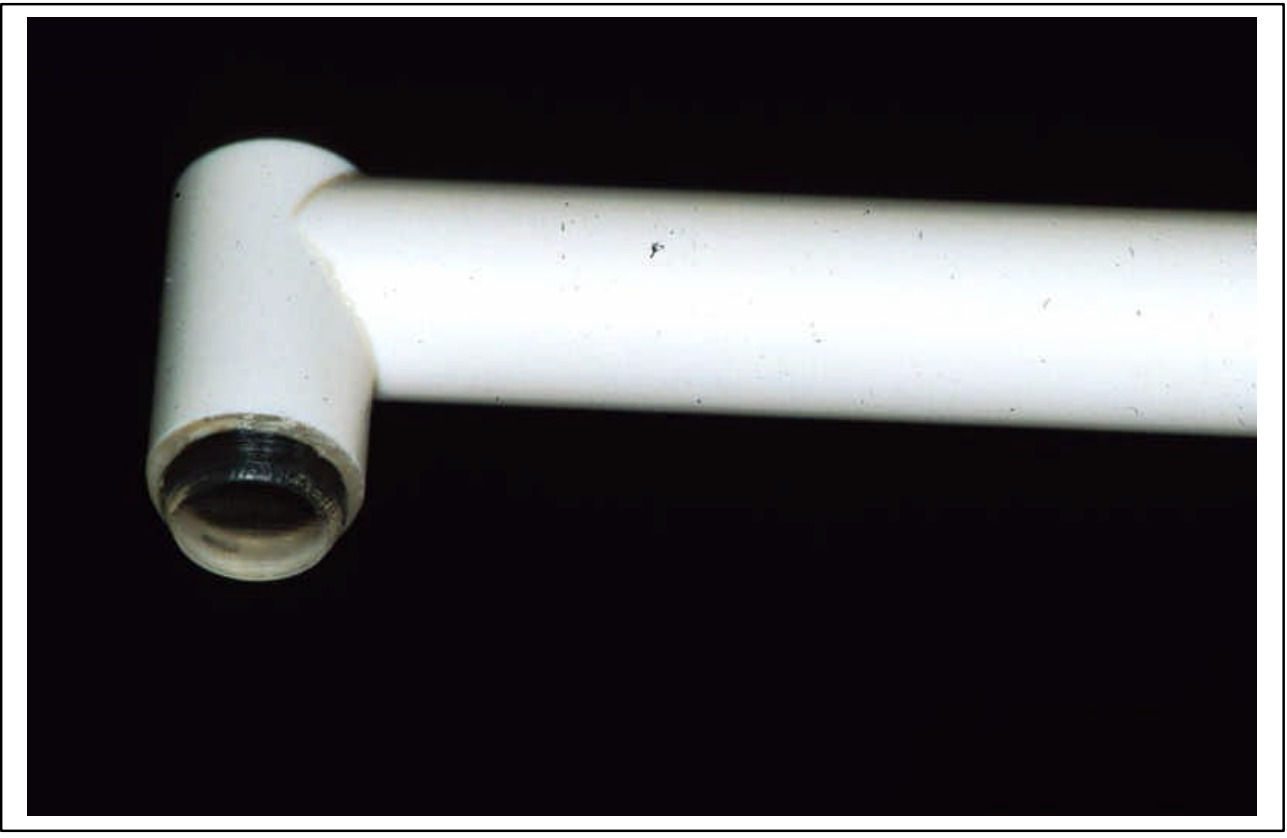

FIGURA 3 - Dimensões da cabeça manométrica, destacando-se o cristal piezo-elétrico

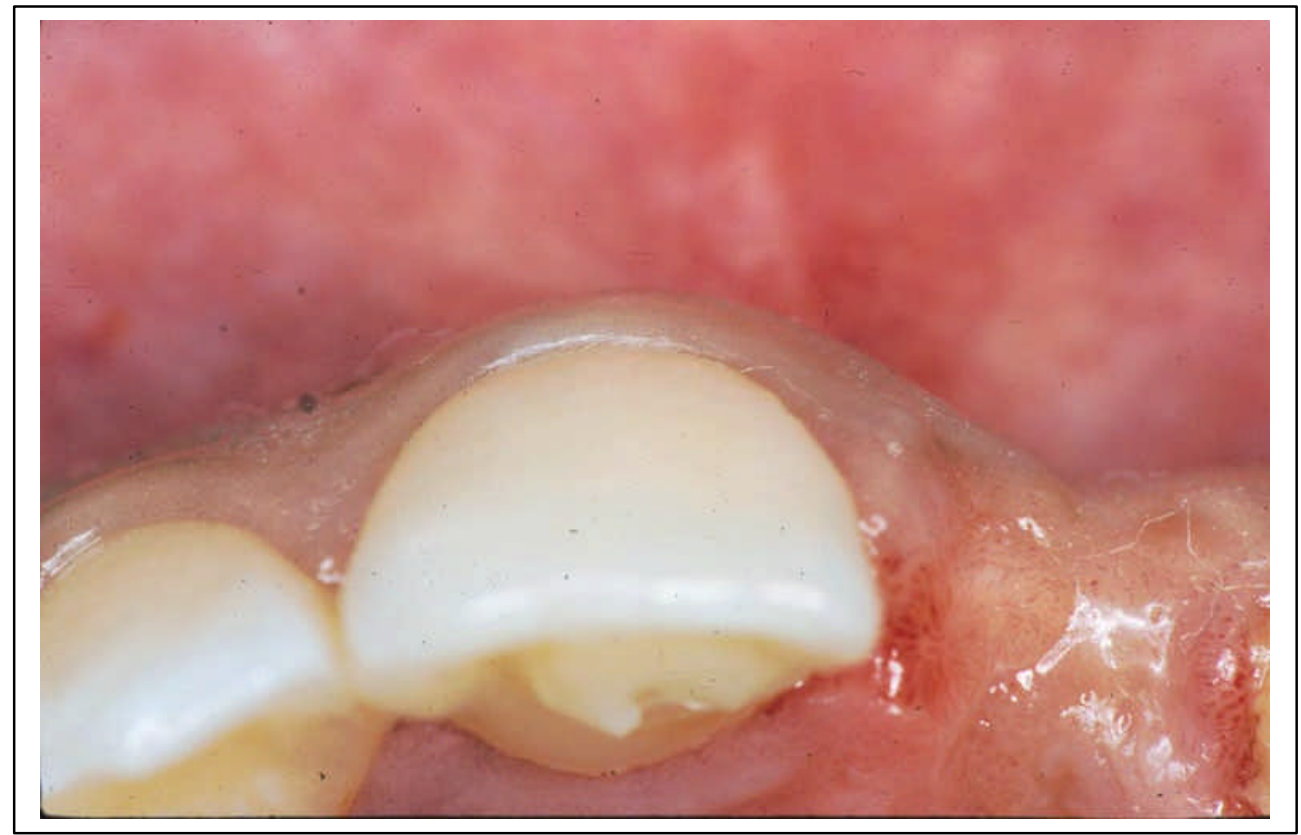

FIGURA 4 - Vista incisal da margem gengival cuja espessura será mensurada 
Material e Métodos - 45

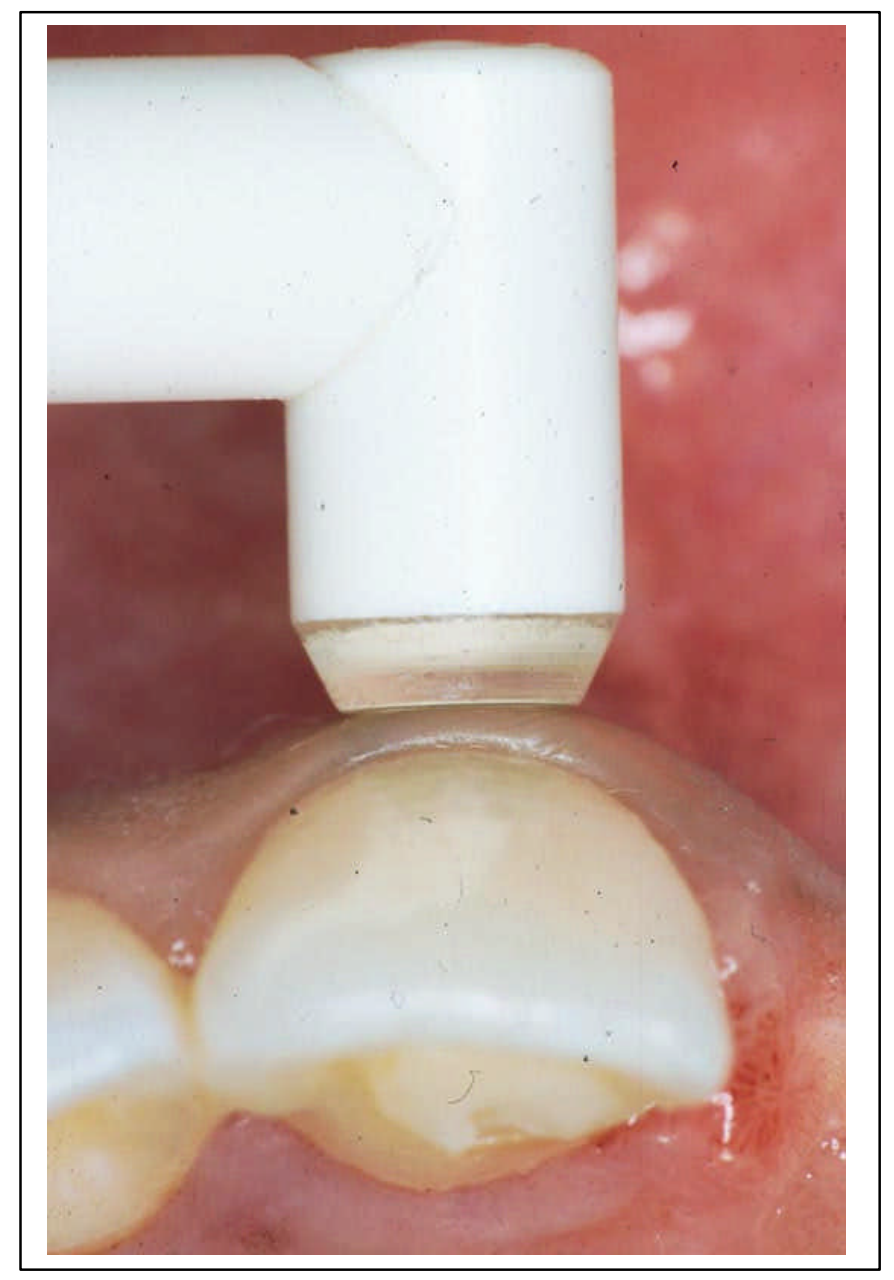

FIGURA 5 - Vista incisal do posicionamento da cabeça manométrica para medição da espessura gengival 
Material e Métodos - 46

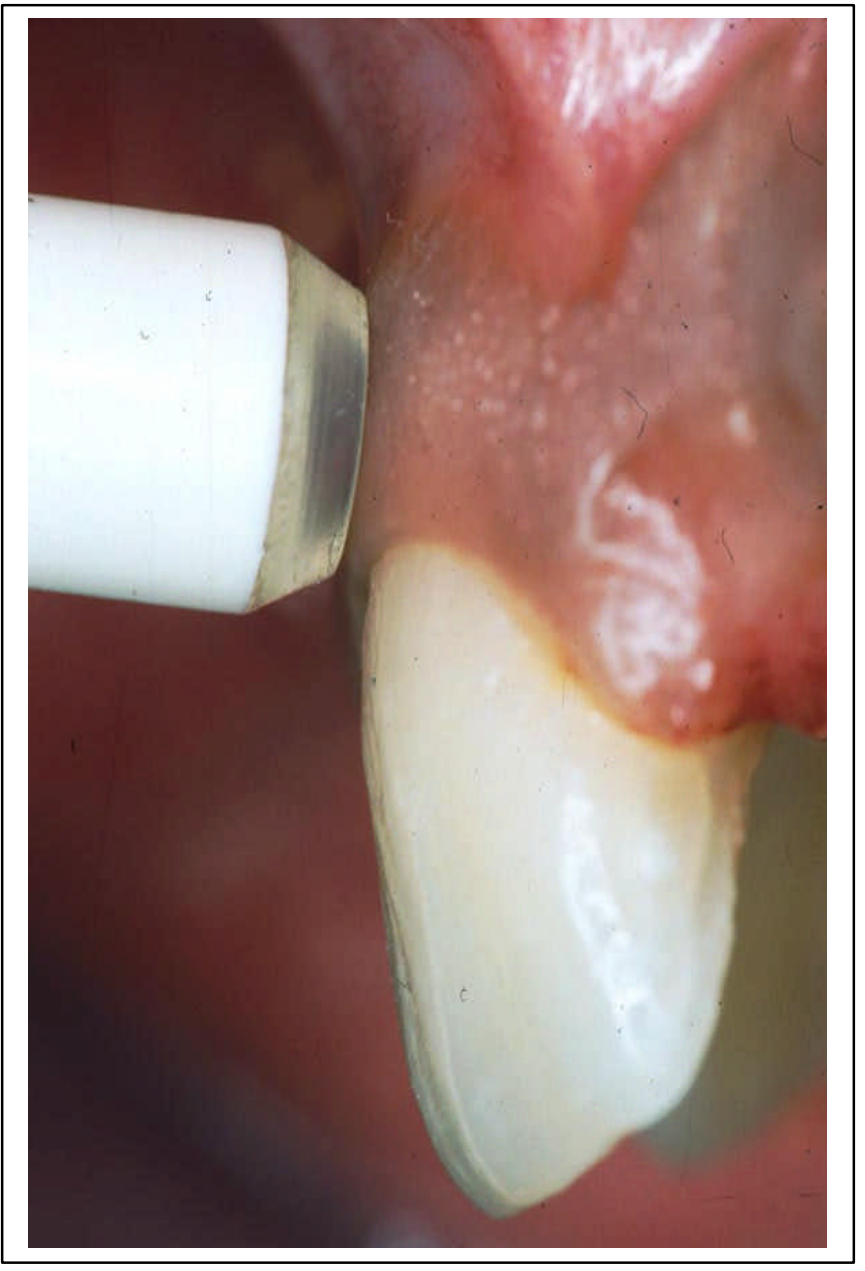

FIGURA 6 - Visão lateral do posicionamento da cabeça manométrica para mensuração da espessura gengival 


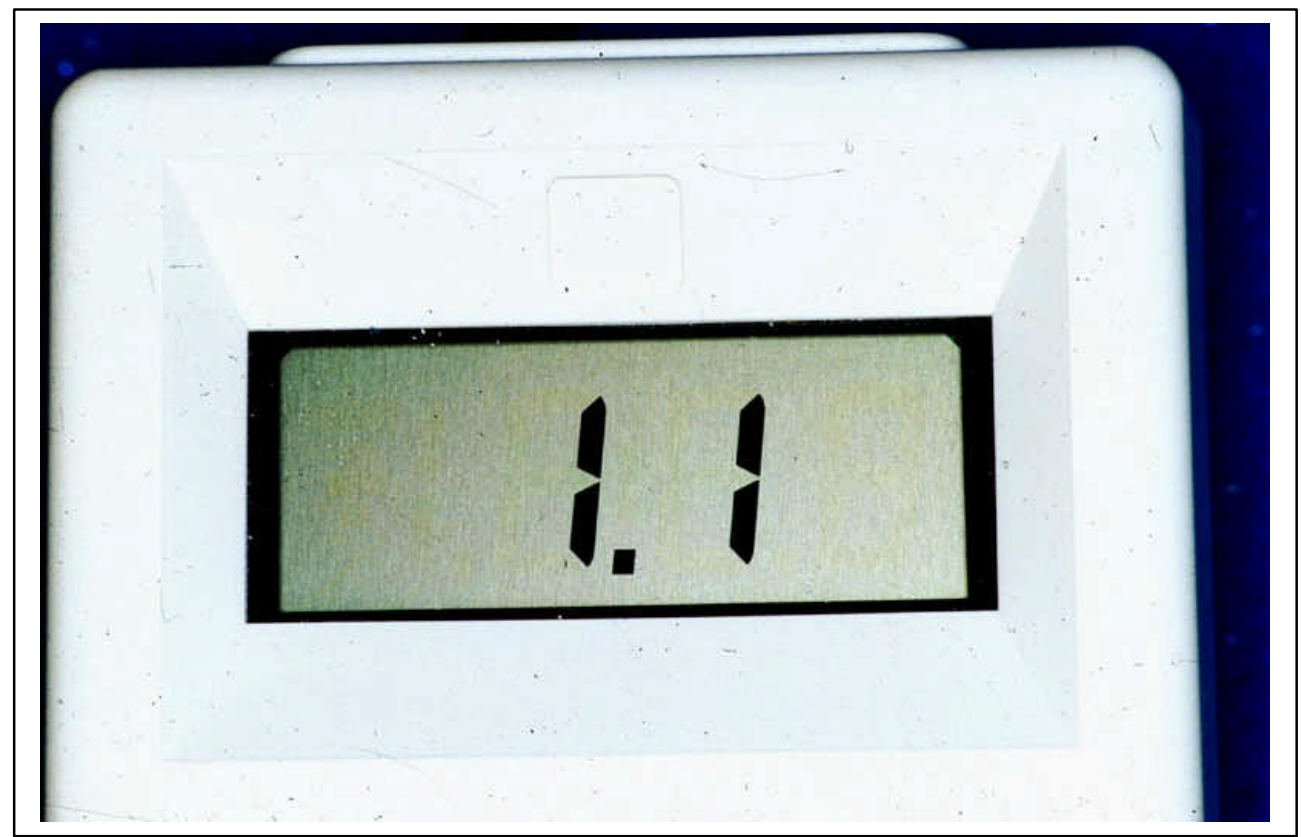

FIGURA 7 - Visor digital do Sonar SDM

Para o manuseamento do equipamento, foram efetuados exames de comparação no mesmo indivíduo, entre o método de sondagem de espessura de tecidos moles tradicional (através de anestesia local e uso de sonda afiada) que provoca sangramento, e a medição pelo uso do sonar SDM. Estes exames comparativos confirmam o alto nível de exatidão e o aumento de conforto que proporciona este novo sistema desenvolvido. O aumento de conforto principalmente significa que, com este aparelho, se pode abranger um número muito superior de pontos de medição, o que aumenta a exatidão do desenho da crista óssea, de rebordos maxilares e do design dos tecidos moles, de uma maneira geral. Além disso, é de fácil percepção que, num perfil de crista não suportado por ossos (perda óssea anterior traumática, dentre outros), não ocorre o sinal refletor. Isto, neste método de medição elimina até quase cem por cento a possibilidade de falsos diagnósticos.

A cabeça manométrica, construída de material plástico não permite autoclavagem. Dessa forma sua desinfecção foi realizada através de produtos químicos. 
Material e Métodos - 48

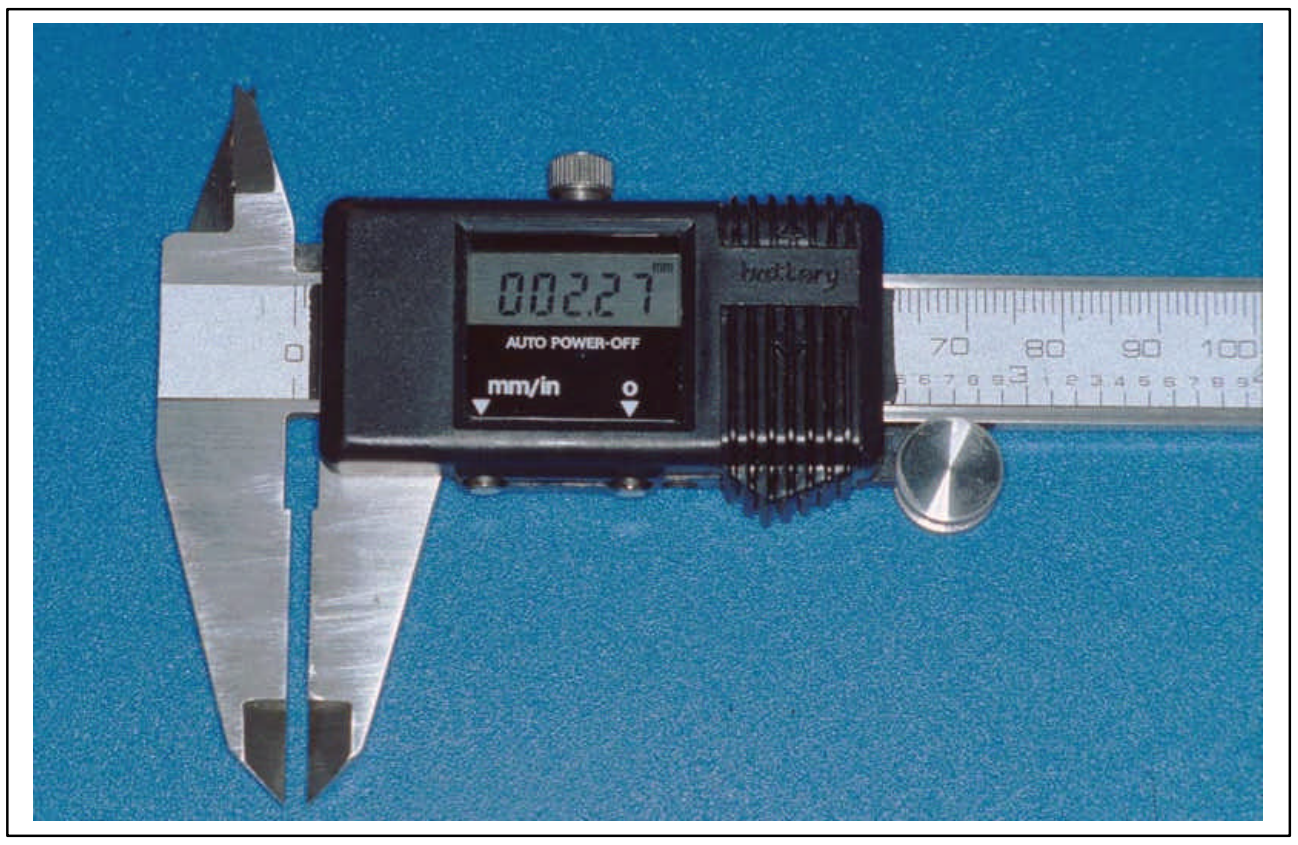

FIGURA 8 - Paquímetro digital 


\subsubsection{LARGURA DA MUCOSA CERATINIZADA (MC - l)}

A medição da largura da mucosa ceratinizada foi feita com paquímetro digital, com as seguintes características:

- Fabricante: Starrett

- Procedência: Brasil

- Especificações técnicas: Cat. No. 727ME/6*/150mm

○ Serial 27510

○ Battery SR44W

Para se trabalhar com o mesmo número de casas decimais das outras medidas, o décimo de milímetro foi arredondado para cima com números centesimais $\geq 6$ e arredondado para baixo com números centesimais $\leq 5$.

O paquímetro, por ser um produto eletrônico não designado e fabricado para suportar altas temperaturas, teve realizado na sua ponta ativa metálica uma desinfecção química.

Com a utilização de um paquímetro eletrônico com capacidade de leitura em centésimos de milímetros (Figuras 8 e 9), foi realizada uma medida por sítio (dente) posicionando-se o paquímetro no centro da face livre vestibular dos dentes adjacentes à área do(s) implante(s) (Figura 10).

Esta localização permite medida bastante precisa em área de fácil visualização e reprodução nesta e nas faces posteriores, no mesmo local onde se medirão a profundidade de sondagem clínica (Figuras 11 e 12) e a distância da margem gengival até a crista óssea (Figuras 13, 14, 15, 16, 17). 


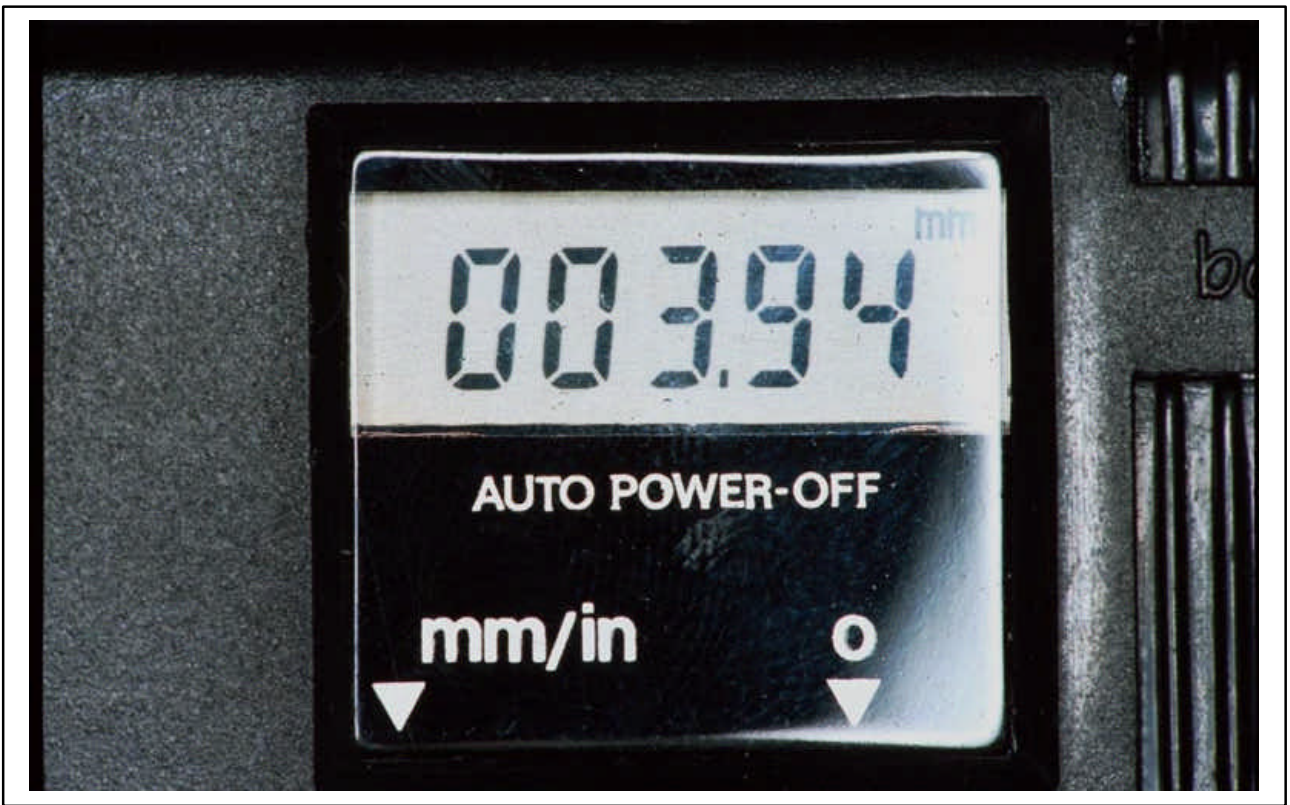

FIGURA 9 - Visor do paquímetro digital

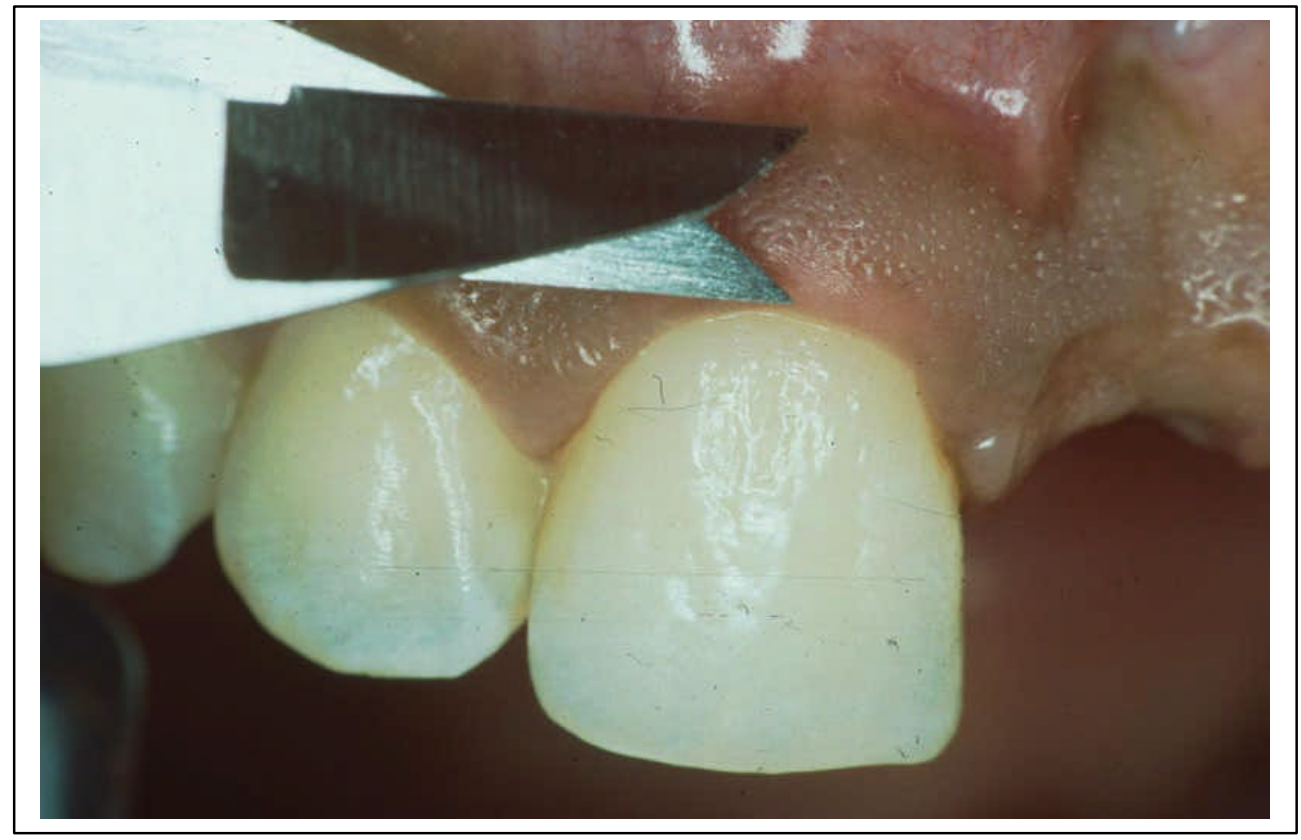

FIGURA 10 - Medição da faixa de mucosa ceratinizada 


\subsubsection{PROFUNDIDADE DE SONDAGEM CLÍNICA (PS)}

Foi utilizada sonda periodontal de "Michigan Ø" (Hu-Friedy), com diâmetro da extremidade da ponta ativa de $0,4 \mathrm{~mm}$, apresentando as marcações de Williams (Figura 11).

Por meio de um único operador foram realizadas 3 medidas para cada sítio, procurando proceder uma mesma calibração de sondagem de forma a procurar empregar aproximadamente força constante de $25 \mathrm{~g}$. Foi considerada como medida final a média das 3 medições individuais, que consideraram intervalos de $0,5 \mathrm{~mm}$, que permitiram portanto obter-se medidas de $1 \frac{1}{2}, 1,1 \frac{1}{2}, 2,2 \frac{1}{2}, 3 \mathrm{~mm}$ e assim por diante (Figura 12).

Todas as medidas realizadas na pesquisa foram feitas com a mesma sonda, que teve sua esterilização efetuada com calor úmido através de vapor sob pressão (autoclave Tuttnauer).

As medidas foram realizadas no sulco gengival localizado no centro da face vestibular dos elementos adjacentes ao local do(s) implante(s) a ser(em) realizado(s)(Figura 12). Neste mesmo local foram feitas as medições da largura da mucosa ceratinizada (Figura 10) e a distância margem gengival-crista óssea (16 e 17). 


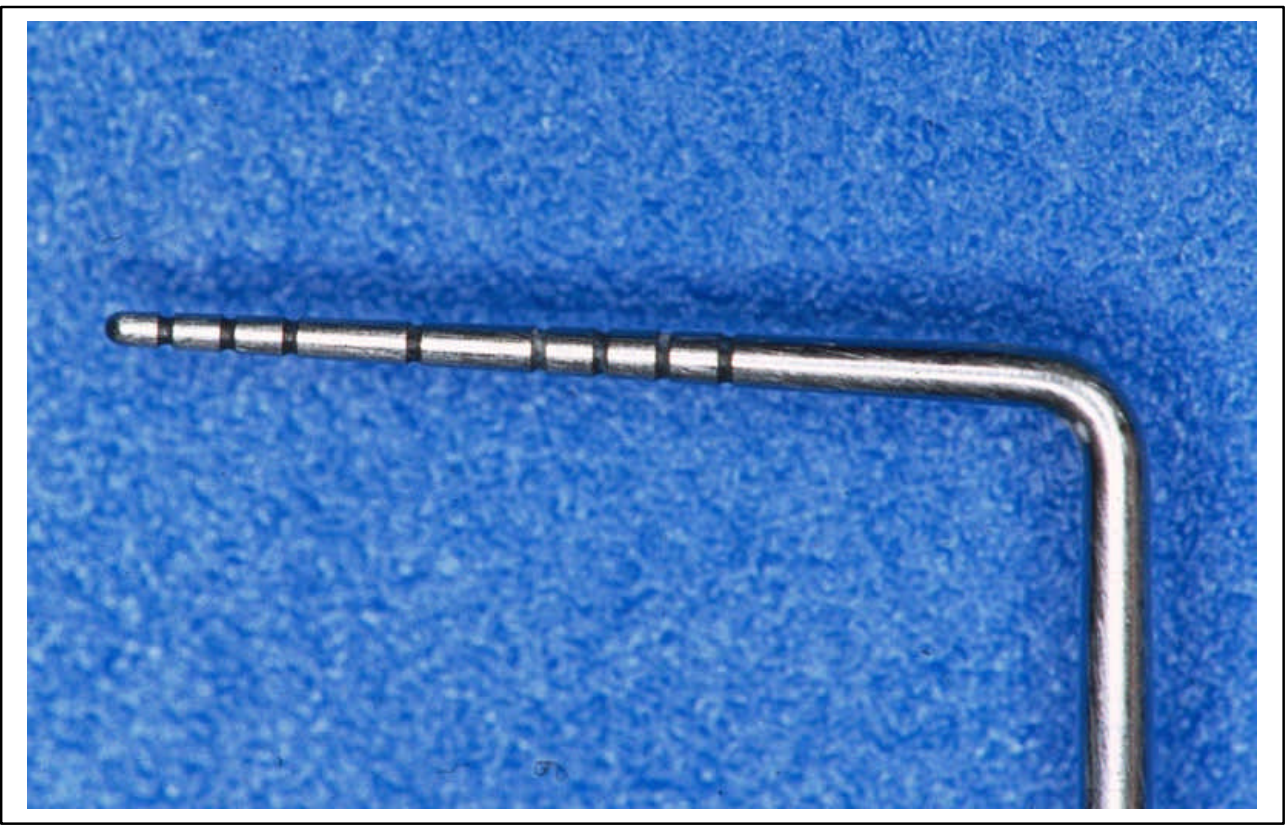

FIGURA 11 - Sonda periodontal milimetrada modelo Michigan

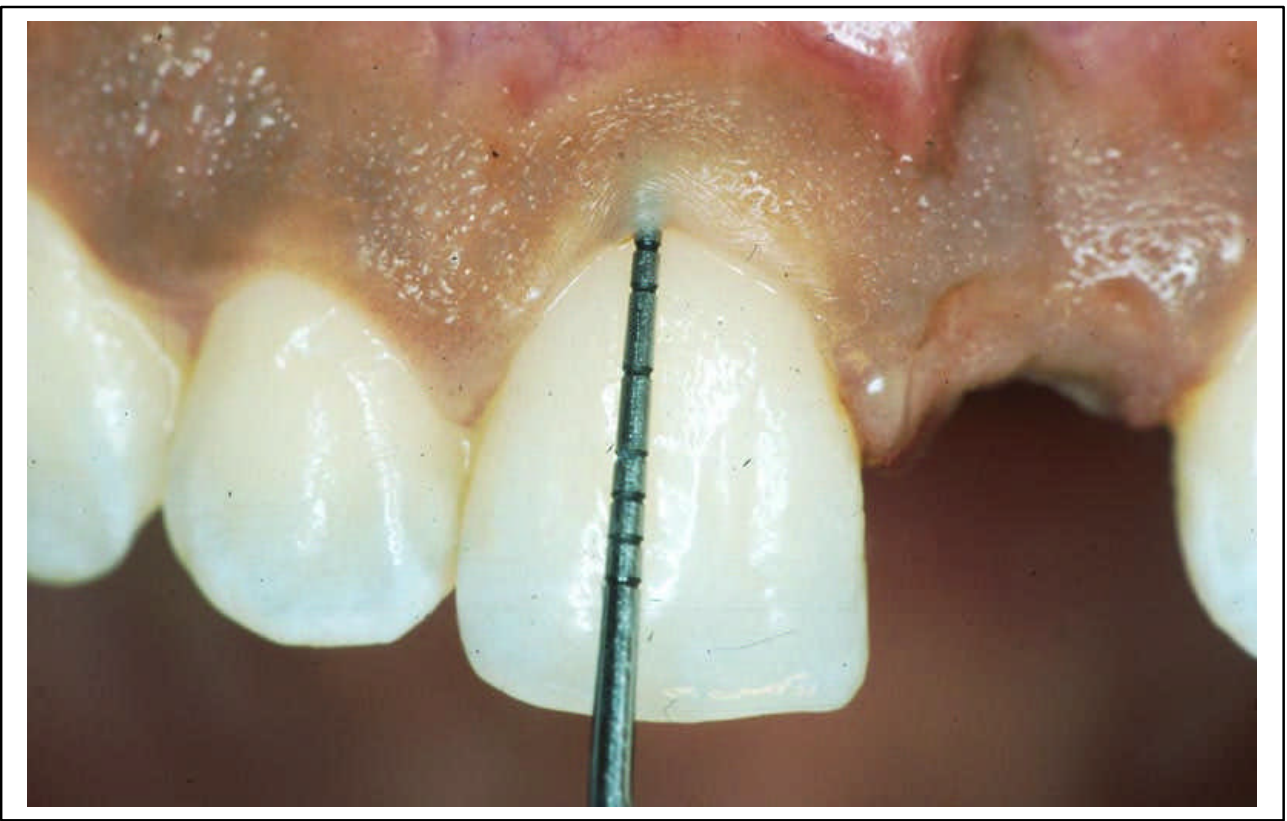

FIGURA 12 - Sondagem do sítio 


\subsection{4 ÍNDICE DE SANGRAMENTO GENGIVAL (ISG)}

Após a realização da medida da profundidade de sondagem clínica com a sonda periodontal, foi observado o escore de sangramento gengival preconizado por MUHLEMANN; SON, 1971(Figura 12) .

Segundo este sistema, a ausência total de sinais visuais de inflamação e/ou placa na unidade gengival é registrada como escore "0"e a presença visual de placa bacteriana e/ou a tendência ao sangramento da margem gengival até 15 segundos após a verificação com a sonda periodontal é registrada como escore "1". Dessa forma, a análise da homeostasia marginal utilizada neste estudo foi realizada de forma dicotômica, ou seja, presença ou ausência de sangramento pós-sondagem.

Como foi realizado um baseline para a padronização da amostra, tendo em vista que os dentes selecionados não apresentavam bolsa periodontal e que foram submetidos à terapia básica prévia, o ISG foi medido como forma de análise da ausência ou presença de inflamação gengival.

Os resultados foram anotados na ficha apropriada. 


\subsubsection{DISTÂNCIA MARGEM GENGIVAL-CRISTA ÓSSEA (MG-CO)}

Após a realização de todas as medidas não invasivas espessura da mucosa gengival marginal, largura da mucosa ceratinizada, profundidade de sondagem clínica e Índice de Sangramento Gengival foram realizadas duas medidas invasivas: a medida da distância da margem gengival até a crista óssea e a espessura desta crista no meio da face livre (onde previamente foram realizadas todas as demais medidas).

Com o auxílio de um lápis comum marca Chainteef grafite número 2 , devidamente autoclavado, foi realizada uma marcação no centro da face vestibular (na superfície do esmalte ou na porção radicular) exatamente coincidente com a margem gengival (Figuras 13, 14 e 16), antes do rebatimento do retalho para acesso à crista óssea para a fixação do(s) implante(s) (Figuras 15 e 16). Para se evitar alterações no volume gengival marginal, o bloqueio de estímulo foi feito à distância.

Com a utilização de um paquímetro eletrônico com capacidade de leitura em centésimos de milímetros (Figuras 8 e 9), foi realizada uma medida por sítio (dente), posicionando-o no centro da face livre vestibular do dente, medindo desde a marca do lápis na superfície dental até a crista óssea (Figuras 16, 17).

O paquímetro, por ser um produto eletrônico não designado e fabricado para suportar altas temperaturas, teve realizada na sua ponta ativa metálica uma desinfecção química. 


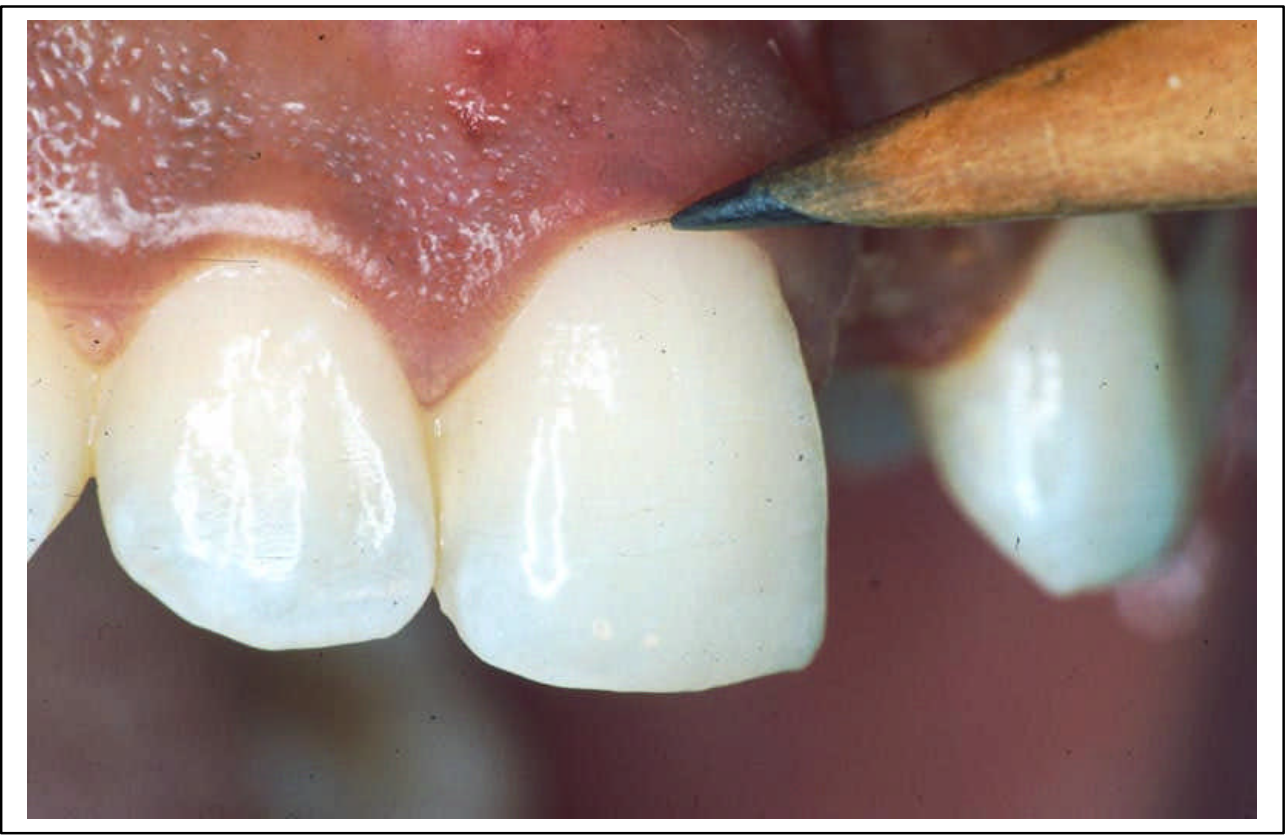

FIGURA 13 - Marcação de posição de margem gengival

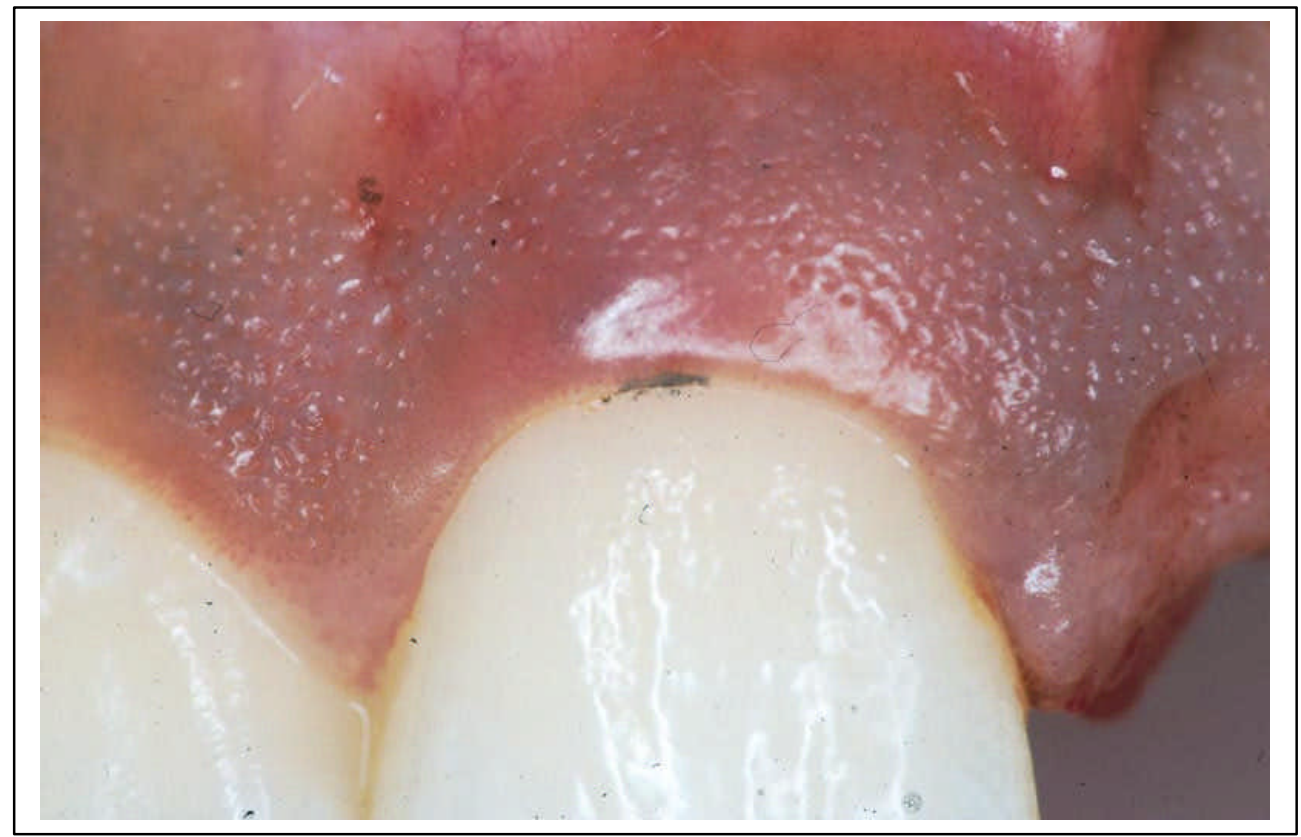

FIGURA 14 - Marcação de posição de margem gengival 


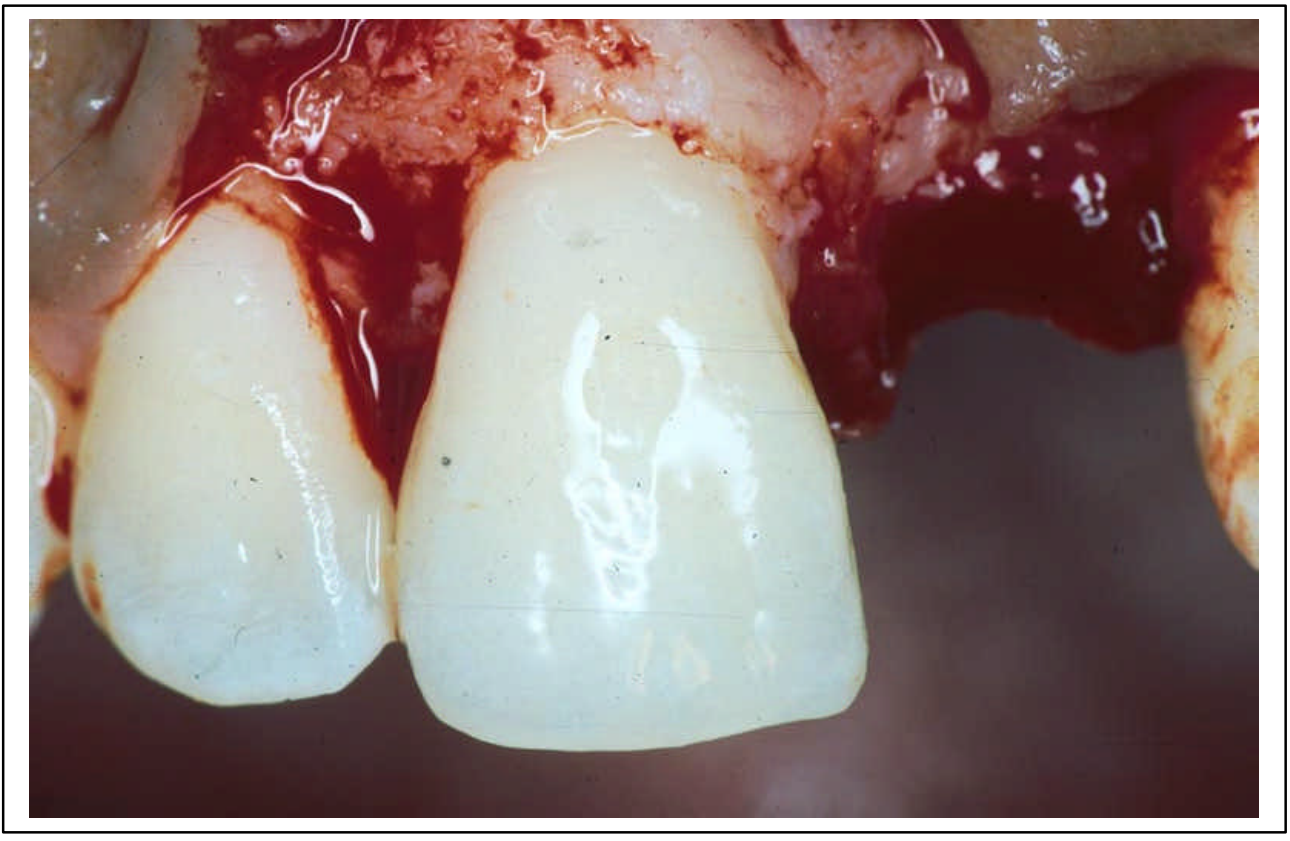

FIGURA 15 - Campo cirúrgico aberto

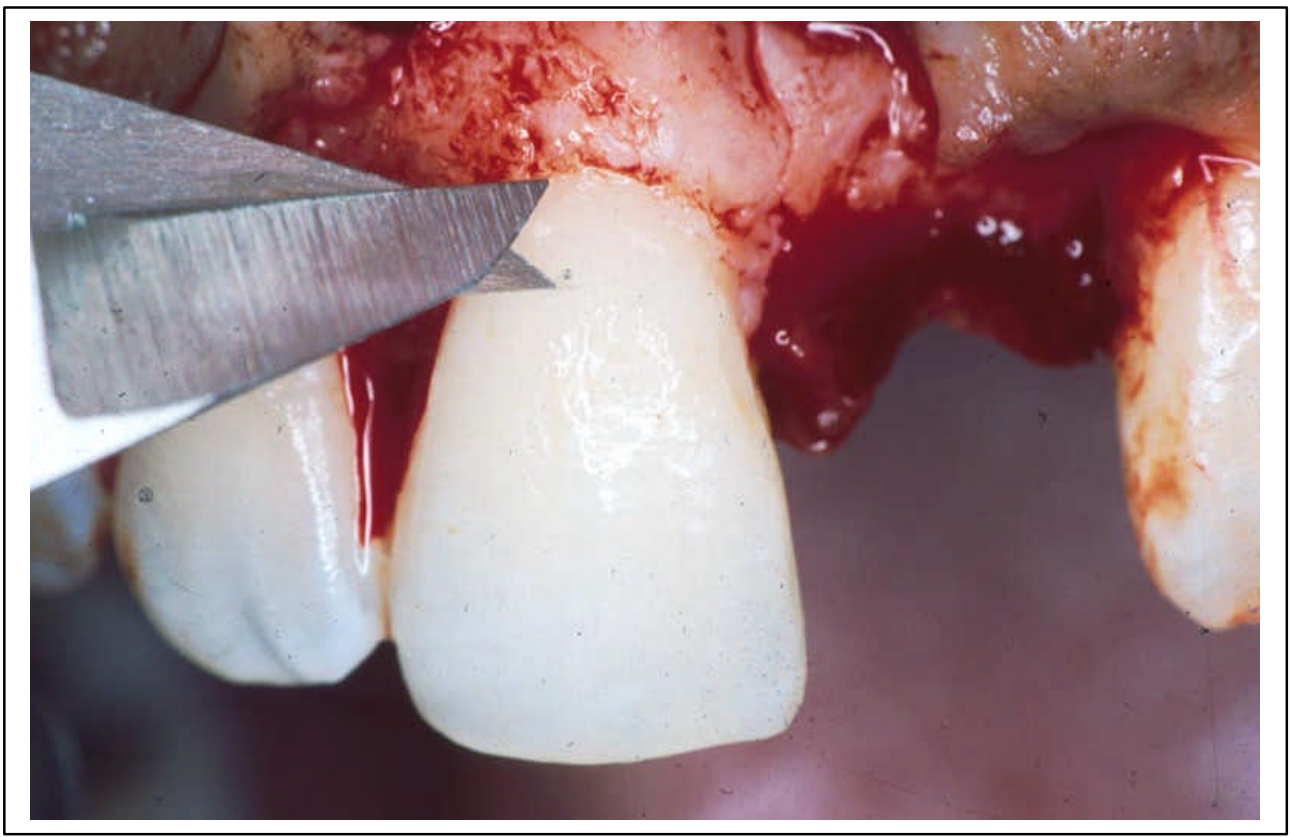

FIGURA 16 - Medição da distância Margem Gengival-Crista Óssea com base na marca a lápis correspondente à margem gengival 


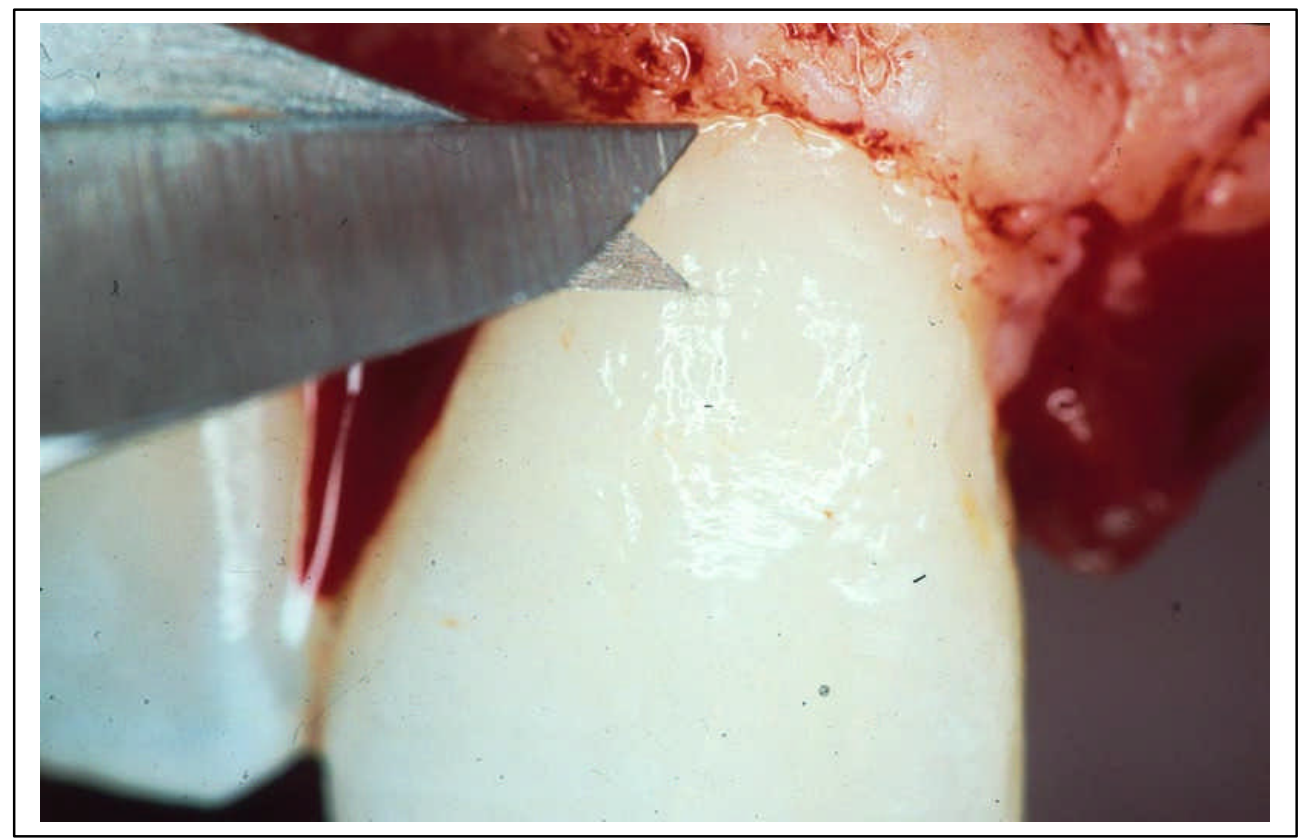

FIGURA 17 - Medição da distância Margem Gengival-Crista Óssea vista com maior aumento da figura anterior 


\subsubsection{ESPESSURA DA CRISTA ÓSSEA (EO)}

A espessura da crista óssea foi classificada em fina, normal ou grossa. A crista normal (Figura 18) foi determinada pelo parâmetro das outras duas. A crista fina foi considerada aquela próxima à uma deiscência, com bossa radicular bem proeminente e cemento quase aparente. Os sítios com deiscência real foram excluídos, por tornarem as medidas das distâncias biológicas extremamente discrepantes. A crista grossa foi considerada aquela semelhante a exostoses ou margens evidentemente engrossadas que não podem ser consideradas como normais. $O$ fato dessa classificação ter sido feita por um único operador tornou-a mais confiável.

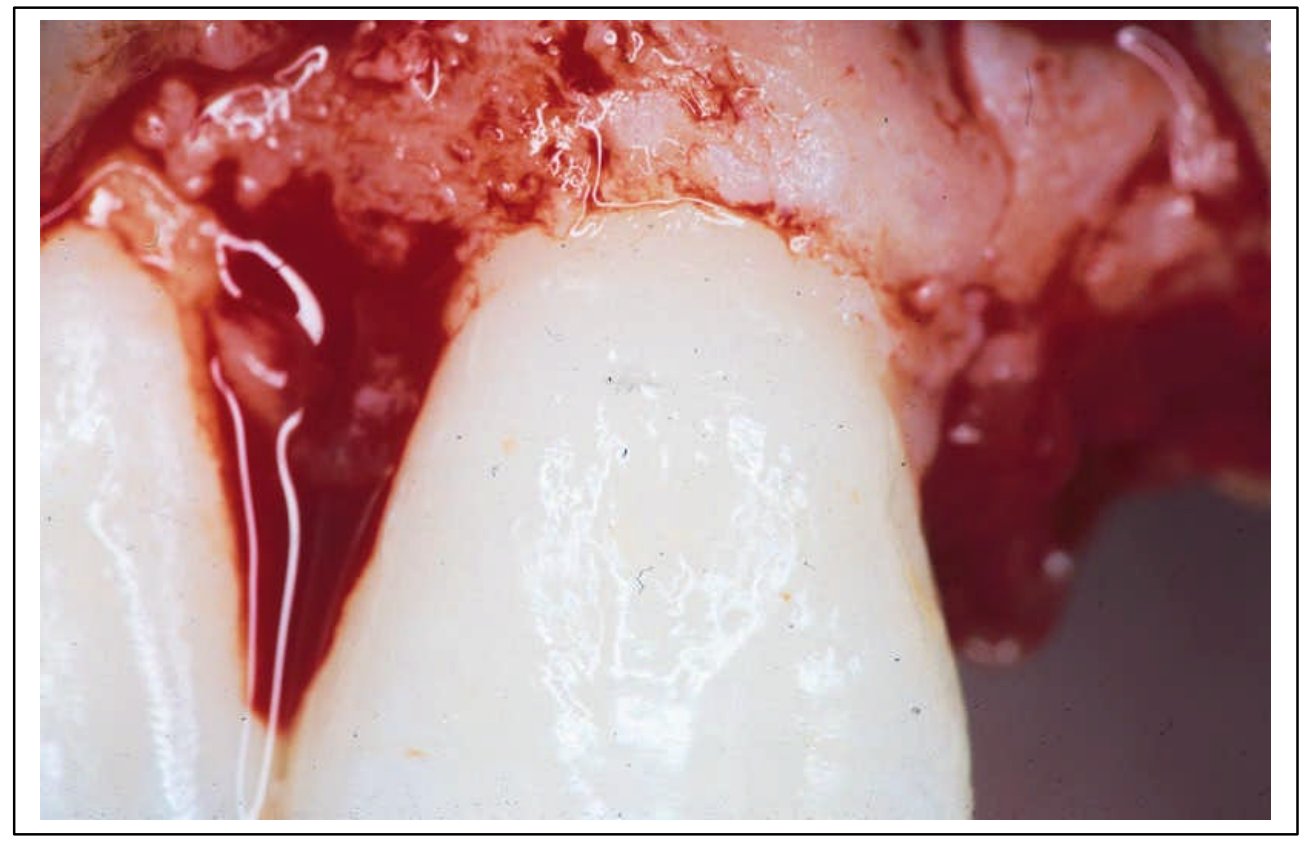

FIGURA 18 - Anatomia da crista óssea com espessura normal 
5 RESULTADOS 


\section{RESULTADOS}

5.1 PARTE I: PARTE DESCRITIVA OU EXPLORATÓRIA (CARACTERIZAÇÃO DA AMOSTRA)

TABELA 1 - Amostra de dentes segundo tipo

\begin{tabular}{l|c|c}
\hline \multirow{2}{*}{ Tipo do dente } & \multicolumn{2}{|c}{ Freqüências } \\
\cline { 2 - 3 } & $\mathrm{n}$ & $\%$ \\
\hline Incisivo & 17 & 25,8 \\
Canino & 19 & 28,8 \\
Pré-molar & 22 & 33,3 \\
Molar & 8 & 12,1 \\
\hline & 66 & 100,0 \\
\hline
\end{tabular}

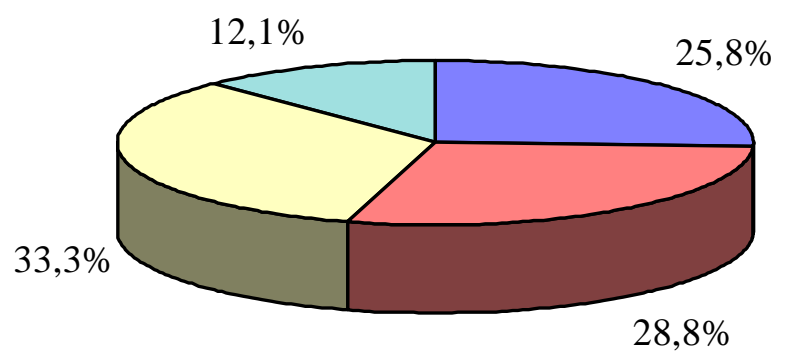

$\square$ Incisivo

$\square$ Canino

$\square$ Pré-molar

$\square$ Molar

FIGURA 20 - Distribuição percentual dos dentes segundo tipo 


\section{TABELA 2 - Estatísticas descritivas das medidas observadas}

\begin{tabular}{l|c|c|c|c}
\hline \multirow{2}{*}{ Medidas } & \multicolumn{4}{c}{ Estatísticas descritivas } \\
\cline { 2 - 5 } & Média & Desvio-padrão & Mínimo & Máximo \\
\hline Profundidade de Sondagem (PS) & 1,78 & 0,44 & 1,0 & 3,0 \\
\hline Largura da mucosa ceratinizada (MC-I) & 2,687 & 1,372 & 0,00 & 6,17 \\
\hline Espessura da mucosa ceratinizada (MC-e) & 1,13 & 0,49 & 0,5 & 2,5 \\
\hline Distância da margem gengival à crista óssea (MG-CO) & 2,507 & 1,107 & 1,06 & 6,50 \\
\hline
\end{tabular}




\section{TABELA 3 - Estatísticas descritivas das medidas observadas segundo grupos de dentes}

\begin{tabular}{|c|c|c|c|c|c|c|}
\hline \multirow{2}{*}{ Medidas } & \multirow{2}{*}{$\begin{array}{c}\text { Tipo do } \\
\text { Dente }\end{array}$} & \multicolumn{4}{|c|}{ Estatísticas descritivas } & \multirow{2}{*}{ p-valor* } \\
\hline & & Média & DP & Mínimo & Máximo & \\
\hline \multirow{2}{*}{$\begin{array}{c}\text { Profundidade } \\
\text { de sondagem }(\mathbf{P S})\end{array}$} & I e C & 1,72 & 0,35 & 1,0 & 2,5 & \multirow{2}{*}{0,415} \\
\hline & PM е M & 1,85 & 0,53 & 1,0 & 3,0 & \\
\hline \multirow{2}{*}{$\begin{array}{l}\text { Largura da mucosa } \\
\text { ceratinizada (MC-I) }\end{array}$} & I e C & 3,175 & 1,387 & 0,00 & 6,17 & \multirow{2}{*}{0,001} \\
\hline & PM е M & 2,100 & 1,115 & 0,00 & 5,00 & \\
\hline \multirow{2}{*}{$\begin{array}{l}\text { Espessura da mucosa } \\
\text { ceratinizada (MC-e) }\end{array}$} & I e C & 1,15 & 0,54 & 0,5 & 2,5 & \multirow{2}{*}{0,933} \\
\hline & PM е M & 1,11 & 0,45 & 0,5 & 2,2 & \\
\hline \multirow{2}{*}{$\begin{array}{l}\text { Distância da margem gengival } \\
\text { à crista óssea (MG-CO) }\end{array}$} & I e C & 2,695 & 1,077 & 1,38 & 6,00 & \multirow{2}{*}{0,025} \\
\hline & PM е M & 2,282 & 1,119 & 1,06 & 6,50 & \\
\hline
\end{tabular}

* p-valor obtido pelo teste de Mann-Whitney

Nota: $\mathrm{DP}=$ desvio-padrão; I=Incisivo; $\mathrm{C}=$ Canino; $\mathrm{PM=Pré-molar;} \mathrm{M}=$ Molar 


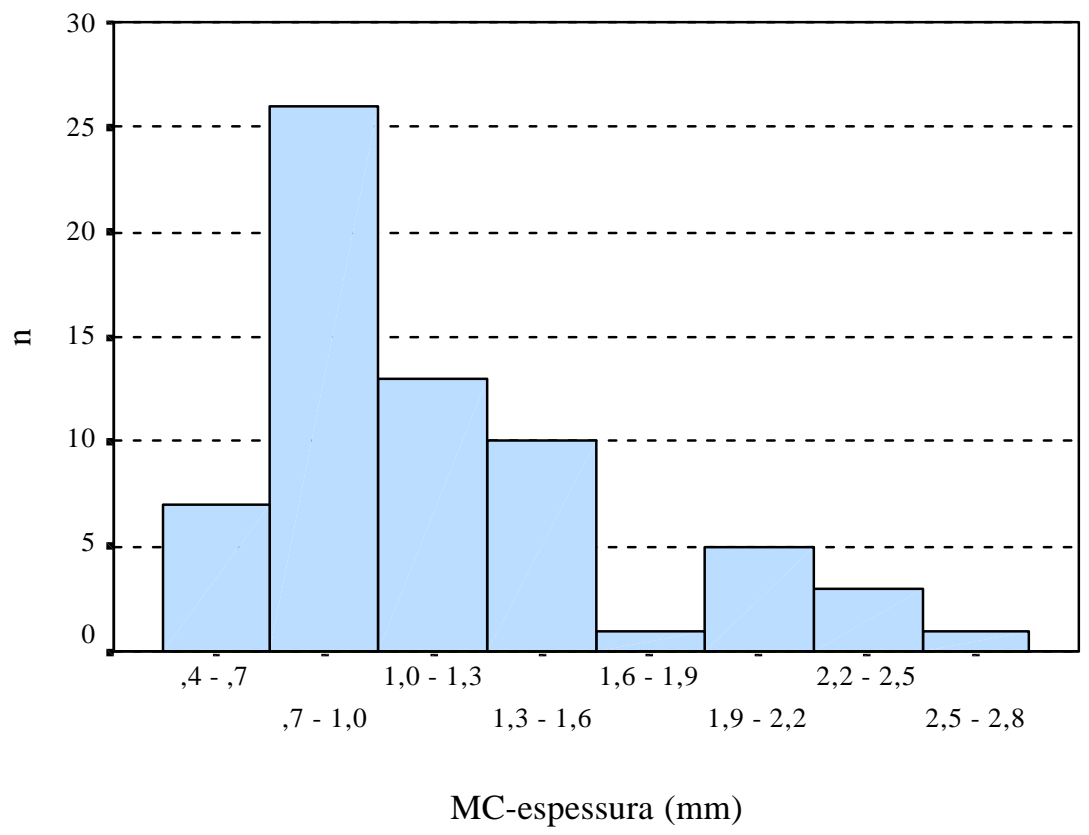

FIGURA 21 - Distribuição da espessura da mucosa ceratinizada em relação ao número de sítios

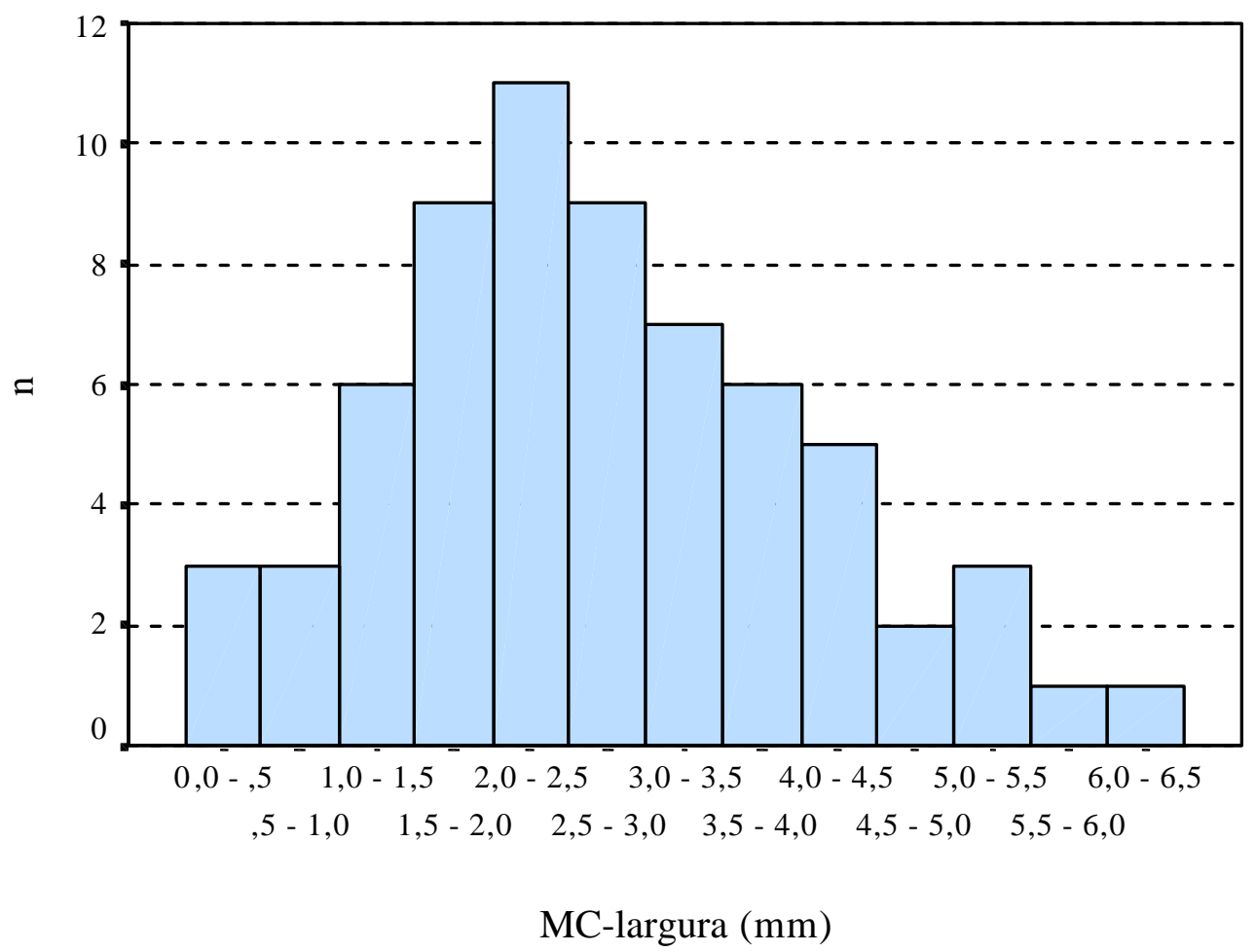

FIGURA 22 - Distribuição da largura da mucosa ceratinizada em relação ao número de sítios 


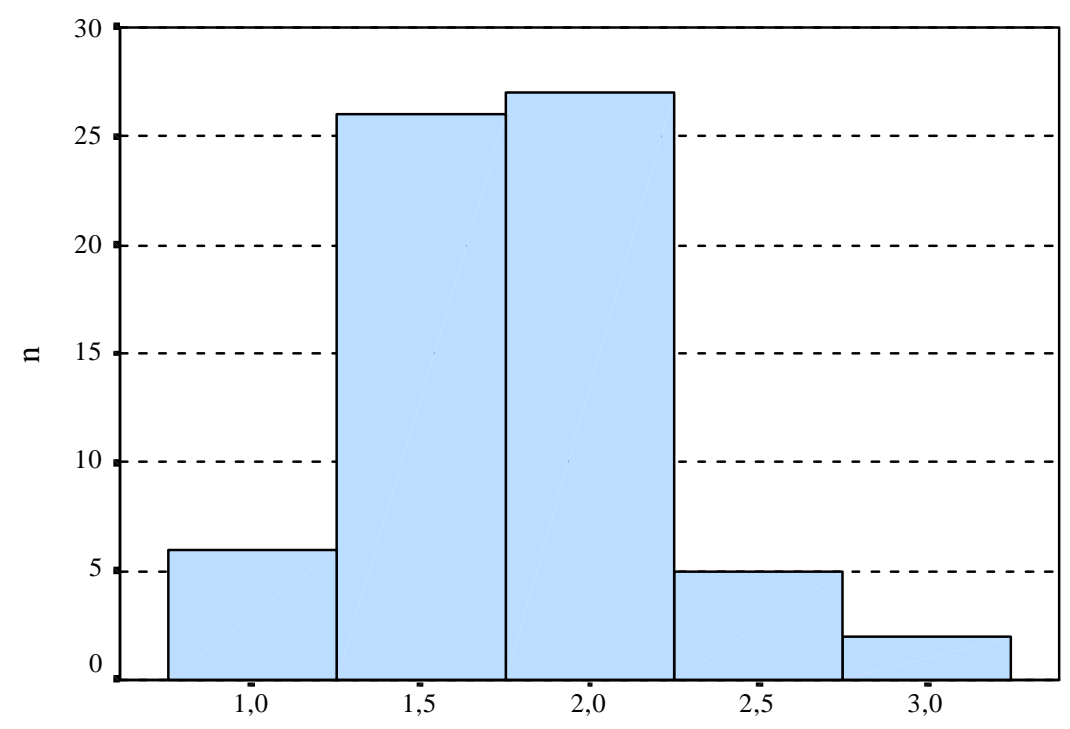

PS (mm)

FIGURA 23 - Distribuição da profundidade de sondagem em relação ao número de sítios

Distância da maroem oenoival à crista óssea

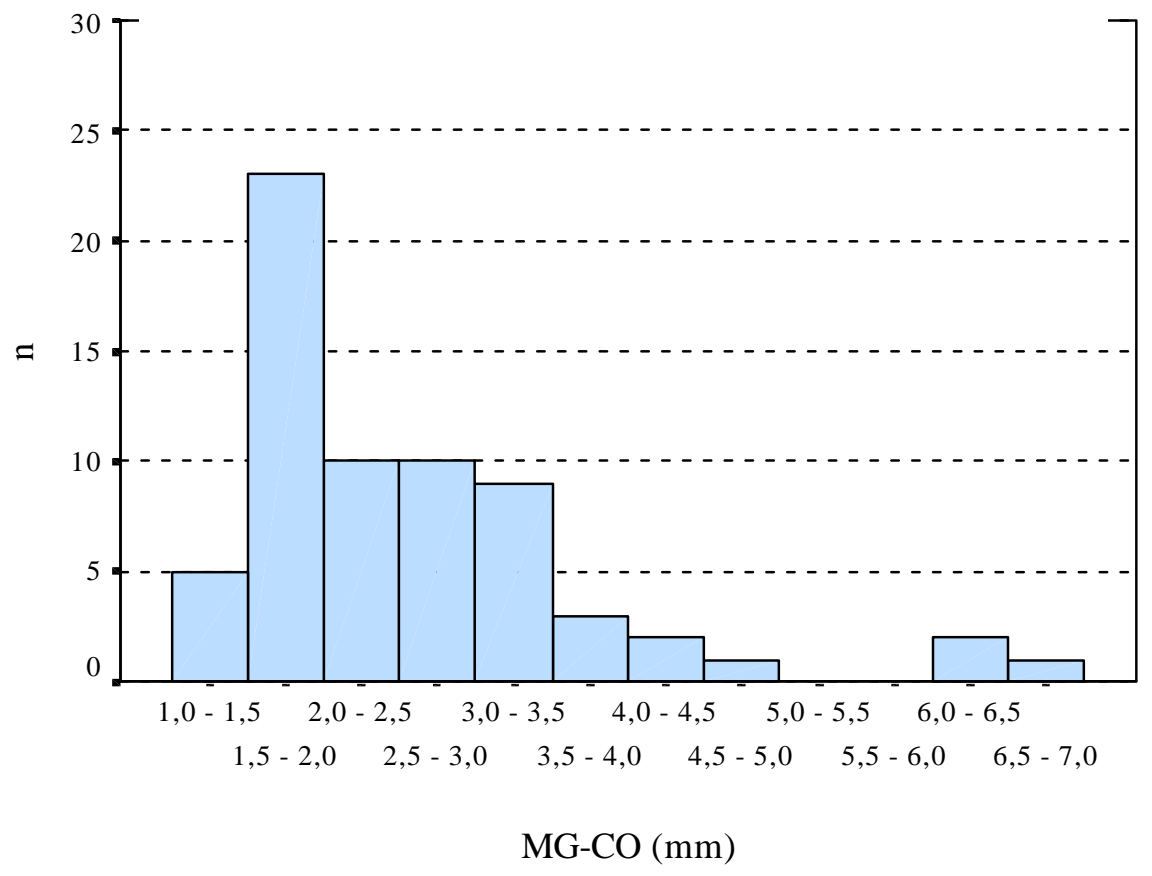

FIGURA 24 - Distribuição da distância da margem gengival à crista óssea em relação ao número de sítios 
TABELA 4 - Índice de sangramento gengival segundo o no de dentes

\begin{tabular}{c|c|c}
\hline \multirow{2}{*}{ Índice de sangramento gengival } & \multicolumn{2}{|c}{ Freqüências } \\
\cline { 2 - 3 } & $\mathrm{n}$ & $\%$ \\
\hline $\mathrm{IG}=0$ & 50 & 75,8 \\
$\mathrm{IG}=1$ & 16 & 24,2 \\
\hline Total & 66 & 100,0 \\
\hline
\end{tabular}

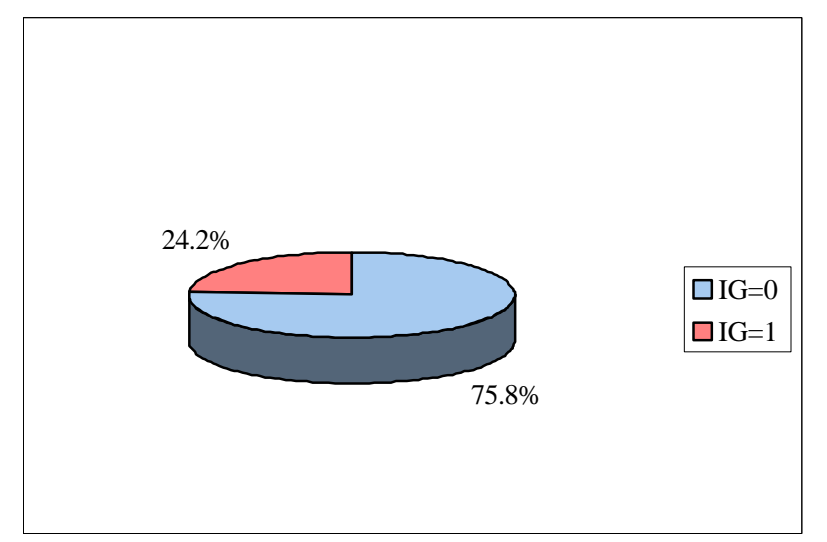

FIGURA 25 - Freqüência percentual de Índice de Sangramento Gengival conforme $o \mathrm{n}^{0}$ de dentes examinados 
TABELA 5 - Índice de Sangramento Gengival segundo grupos de dentes

\begin{tabular}{l|ccc|c|c|c|c}
\hline \multirow{2}{*}{ Tipo de dente } & \multicolumn{3}{|c|}{ Total } & \multicolumn{3}{|c|}{ Índice gengival } \\
\cline { 5 - 8 } & $\mathrm{n}$ & $\%$ & $\mathrm{c}$ & $\mathrm{IG}=0$ & \multicolumn{2}{c}{$\mathrm{IG}=1$} \\
\cline { 5 - 8 } & $36=54,6 \%$ & 100,0 & 30 & 83,3 & 6 & 16,7 \\
\hline $\begin{array}{l}\text { Incisivos e caninos } \\
\text { Pré-molares e } \\
\text { molares }\end{array}$ & $30=45,4 \%$ & 100,0 & 20 & 66,7 & 10 & 33,3 \\
\hline \multicolumn{1}{c}{ Total } & 66 & 100,0 & 50 & 75,8 & 16 & 24,2 \\
\hline
\end{tabular}

Nota: Teste $\chi^{2}: \mathrm{p}$-valor $=0,116$

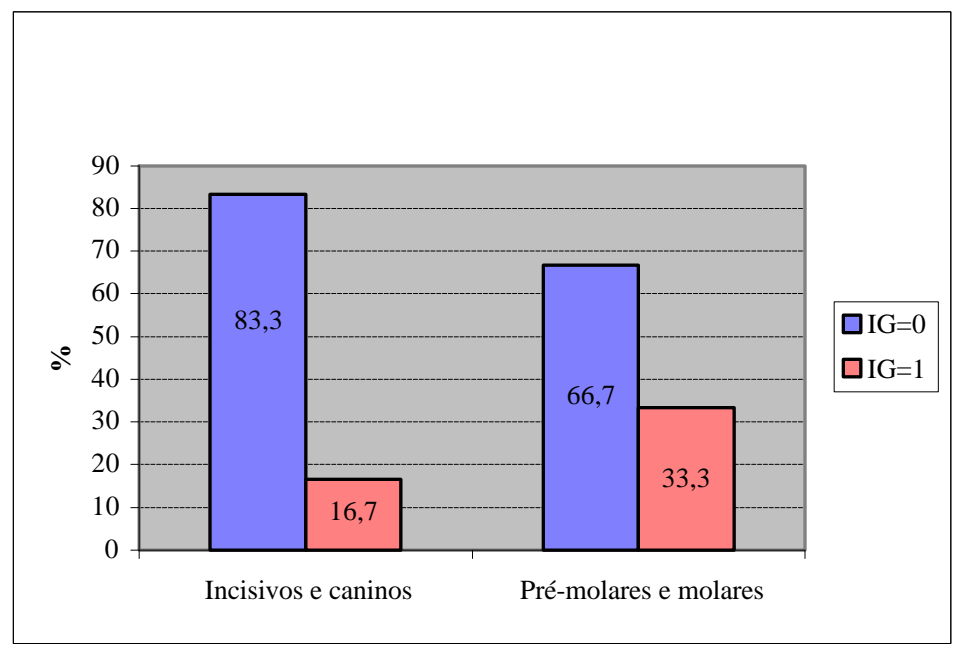

FIGURA 26 - Percentual da freqüência do Índice de Sangramento Gengival segundo grupos de dentes 
TABELA 6 - Índice de Sangramento Gengival segundo o número de dentes e espessura óssea

\begin{tabular}{|c|c|c|c|c|c|c|c|c|}
\hline \multirow{3}{*}{ Índice gengival } & \multirow{2}{*}{\multicolumn{2}{|c|}{ Total }} & \multicolumn{6}{|c|}{ Espessura óssea } \\
\hline & & & \multicolumn{2}{|c|}{ Fina } & \multicolumn{2}{|c|}{ Normal } & \multicolumn{2}{|c|}{ Grossa } \\
\hline & $\mathrm{n}$ & $\%$ & $\mathrm{n}$ & $\%$ & $\mathrm{n}$ & $\%$ & $\mathrm{n}$ & $\%$ \\
\hline $\mathrm{IG}=0$ & $50=75,8 \%$ & 100,0 & 8 & 16,0 & 30 & 60,0 & 12 & 24,0 \\
\hline $\mathrm{IG}=1$ & $16=24,2 \%$ & 100,0 & 9 & 56,3 & 6 & 37,5 & 1 & 6,3 \\
\hline Total & $66=100 \%$ & 100,0 & 17 & 25,8 & 36 & 54,5 & 13 & 19,7 \\
\hline
\end{tabular}

Nota: Teste $\chi^{2}: \mathrm{p}$-valor $=0,005$

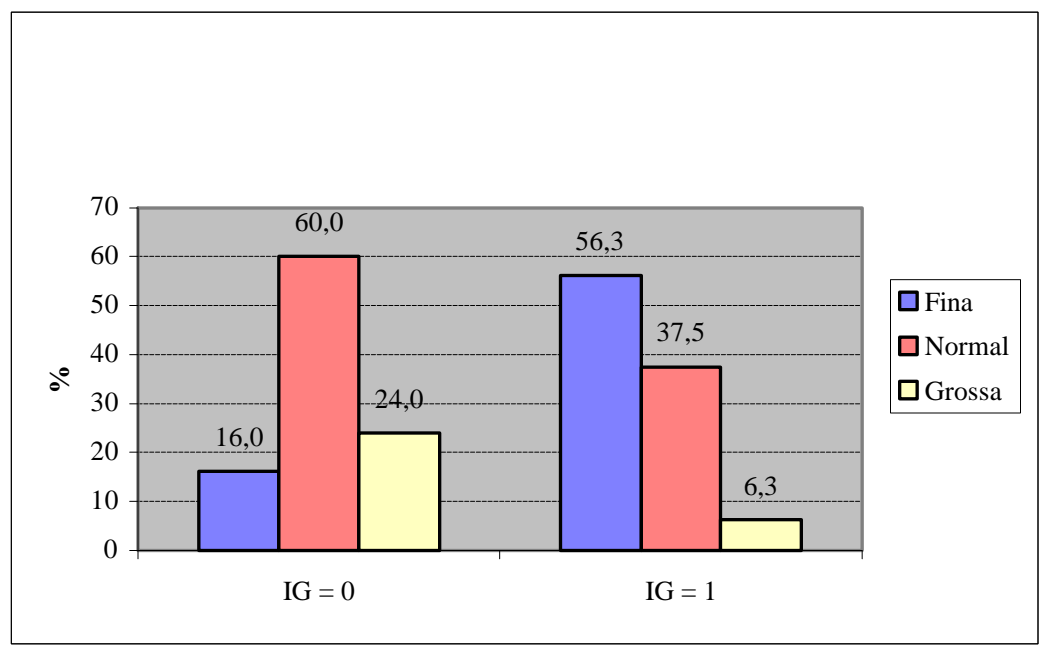

FIGURA 27 - Percentual da frequência do Índice de Sangramento Gengival segundo a espessura óssea 


\section{TABELA 7 - Freqüência da espessura óssea segundo $n^{0}$ de dentes}

\begin{tabular}{l|c|c}
\hline \multirow{2}{*}{ Espessura óssea } & \multicolumn{2}{|c}{ Frequiêcias } \\
\cline { 2 - 3 } & $\mathrm{n}$ & $\%$ \\
\hline Fina & 17 & 25,8 \\
Normal & 36 & 54,5 \\
Grossa & 13 & 19,7 \\
\hline & 66 & 100,0 \\
\hline
\end{tabular}

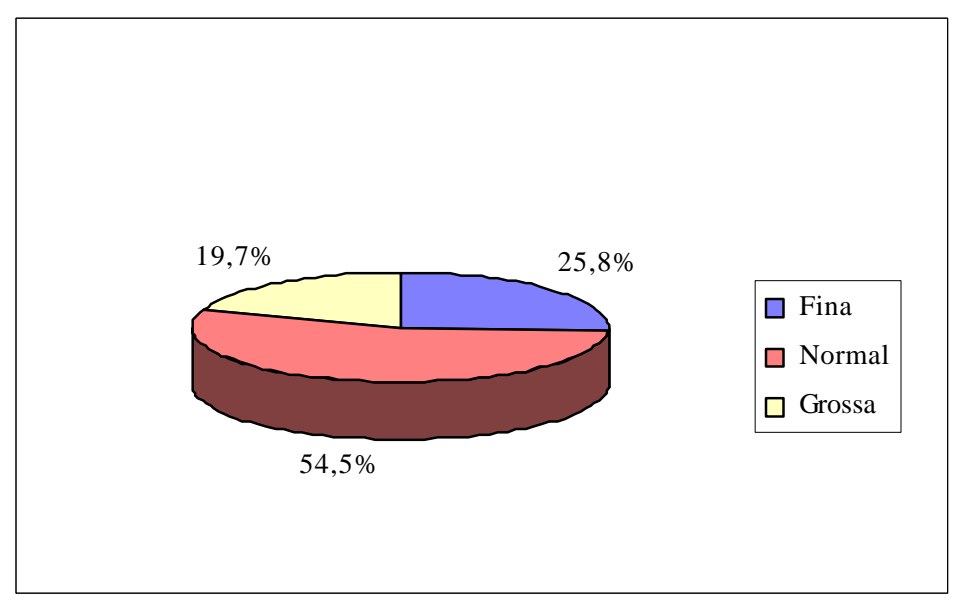

FIGURA 28 - Distribuição percentual da espessura óssea segundo o $\mathrm{n}^{0}$ de dentes 
Resultados - 68

TABELA 8 - Espessura óssea segundo tipo de dente

\begin{tabular}{|c|c|c|c|c|c|c|c|c|}
\hline \multirow{3}{*}{$\begin{array}{c}\text { Tipo } \\
\text { de } \\
\text { dente }\end{array}$} & \multirow[b]{3}{*}{$\mathrm{n}$} & \multirow[b]{3}{*}{$\%$} & \multicolumn{3}{|c|}{ Espessura óssea } & \multicolumn{3}{|c|}{ (\%por grupo de dentes) } \\
\hline & & & \multicolumn{2}{|c|}{ Fina } & \multicolumn{2}{|c|}{ Normal } & \multicolumn{2}{|c|}{ Grossa } \\
\hline & & & $\mathrm{n}$ & $\%$ & $\mathrm{n}$ & $\%$ & $\mathrm{n}$ & $\%$ \\
\hline Incisivo & $17=25,8 \%$ & 100,0 & 1 & 5,9 & 12 & 70,6 & 4 & 23,5 \\
\hline Canino & $19=28,8 \%$ & 100,0 & 5 & 26,3 & 11 & 57,9 & 3 & 15,8 \\
\hline Pré-molar & $22=33,3 \%$ & 100,0 & 10 & 45,5 & 10 & 45,5 & 2 & 9,1 \\
\hline Molar & $8=12,1 \%$ & 100,0 & 1 & 12,5 & 3 & 37,5 & 4 & 50,0 \\
\hline Total & $66=100 \%$ & 100,0 & 17 & 25,8 & 36 & 54,5 & 13 & 19,7 \\
\hline
\end{tabular}


TABELA 9 - Espessura óssea segundo grupos de dentes

\begin{tabular}{l|c|c|c|c|c|c|c|c}
\hline \multirow{2}{*}{ Grupos de dente } & \multicolumn{3}{|c|}{ Total } & \multicolumn{2}{c}{ Espessura óssea } \\
\cline { 5 - 10 } & \multicolumn{2}{|c}{$\mathrm{n}$} & $\%$ & $\mathrm{c}$ Fina & \multicolumn{2}{c}{ Normal } & \multicolumn{2}{c}{ Grossa } \\
\cline { 5 - 11 } & & $\mathrm{n}$ & $\%$ & $\mathrm{n}$ & $\%$ & $\mathrm{n}$ & $\%$ \\
\hline Incisivos e caninos & $36=54,6 \%$ & 100,0 & 6 & 16,7 & 23 & 63,9 & 7 & 19,4 \\
Pré-molares e molares & $30=45,5 \%$ & 100,0 & 11 & 36,7 & 13 & 43,3 & 6 & 20,0 \\
\hline \multirow{2}{*}{ Total } & $66=100 \%$ & 100,0 & 17 & 25,8 & 36 & 54,5 & 13 & 19,7 \\
\hline
\end{tabular}

Nota: Teste $\chi^{2}: \mathrm{p}$-valor $=0,149$

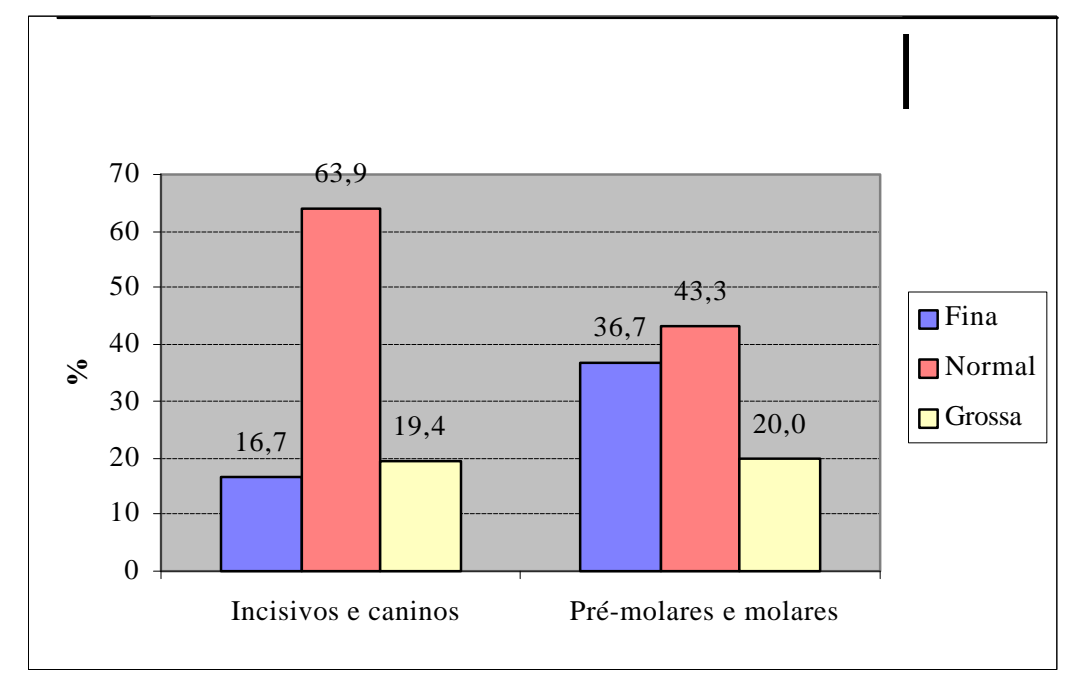

FIGURA 29 - Freqüência pecentual da espessura óssea segundo grupos de dentes 


\subsection{PARTE II: ANÁLISE DA ASSOCIAÇÃO DAS VARIÁVEIS ESTUDADAS}

\section{TABELA 10 - Estatísticas descritivas das medidas observadas segundo espessura óssea}

\begin{tabular}{c|r|r|c|c|c|c}
\hline \multirow{2}{*}{ Medidas } & \multirow{2}{*}{$\begin{array}{c}\text { Espessura } \\
\text { Óssea }\end{array}$} & \multicolumn{4}{|c|}{ Estatísticas descritivas } & \multirow{2}{*}{ p-valor* } \\
\cline { 3 - 6 } & Média & DP & Mínimo & Máximo & \\
\hline Profundidade & Fina & 1,71 & 0,44 & 1,0 & 2,5 & \\
de & Normal & 1,79 & 0,37 & 1,0 & 2,5 & \multirow{2}{*}{0,835} \\
sondagem (PS) & Grossa & 1,85 & 0,63 & 1,0 & 3,0 & \\
\hline Largura & Fina & 2,386 & 1,607 & 0,00 & 5,55 & \\
da mucosa & Normal & 2,585 & 1,282 & 0,00 & 6,17 & \multirow{2}{*}{0,106} \\
ceratinizada (MC-I) & Grossa & 3,361 & 1,143 & 1,50 & 5,35 & \\
\hline Espessura & Fina & 1,08 & 0,45 & 0,5 & 2,1 & \\
da mucosa & Normal & 1,07 & 0,44 & 0,5 & 2,5 & \multirow{2}{*}{0,528} \\
ceratinizada (MC-e) & Grossa & 1,37 & 0,64 & 0,7 & 2,3 & \\
\hline Distância da margem & Fina & 2,745 & 1,171 & 1,75 & 6,00 & \multirow{2}{*}{0,406} \\
gengival à & Normal & 2,508 & 1,174 & 1,06 & 6,50 & 0,406 \\
crista óssea (MG-CO) & Grossa & 2,195 & 0,781 & 1,29 & 4,00 & \\
\hline
\end{tabular}

* p-valor obtido pelo teste de Kruskall-Wallis

Nota: DP=Desvio-padrão 


\section{TABELA 11 - Estatísticas descritivas das medidas observadas segundo o índice gengival}

\begin{tabular}{|c|c|c|c|c|c|c|}
\hline \multirow{2}{*}{ Medidas } & \multirow{2}{*}{$\begin{array}{l}\text { Índice } \\
\text { gengival }\end{array}$} & \multicolumn{4}{|c|}{ Estatísticas descritivas } & \multirow{2}{*}{ p-valor* } \\
\hline & & Média & DP & Mínimo & Máximo & \\
\hline \multirow{2}{*}{$\begin{array}{c}\text { Profundidade } \\
\text { de sondagem (PS) }\end{array}$} & $\mathbf{I G}=\mathbf{0}$ & 1,75 & 0,44 & 1,0 & 3,0 & \multirow{2}{*}{0,241} \\
\hline & $\mathbf{I G}=1$ & 1,88 & 0,43 & 1,0 & 2,5 & \\
\hline \multirow{2}{*}{$\begin{array}{l}\text { Largura da mucosa } \\
\text { ceratinizada (MC-I) }\end{array}$} & $\mathbf{I G}=\mathbf{0}$ & 2,659 & 1,307 & 0,00 & 5,55 & \multirow{2}{*}{0,753} \\
\hline & $\mathbf{I G}=\mathbf{1}$ & 2,772 & 1,600 & 0,00 & 6,17 & \\
\hline \multirow{2}{*}{$\begin{array}{l}\text { Espessura da mucosa } \\
\text { ceratinizada (MC-e) }\end{array}$} & $\mathbf{I G}=\mathbf{0}$ & 1,13 & 0,50 & 0,5 & 2,4 & \multirow{2}{*}{0,792} \\
\hline & $\mathbf{I G}=\mathbf{1}$ & 1,13 & 0,50 & 0,5 & 2,5 & \\
\hline \multirow{2}{*}{$\begin{array}{l}\text { Distância da margem gengival } \\
\text { à crista óssea (MG-CO) }\end{array}$} & $\mathbf{I G}=0$ & 2,468 & 1,183 & 1,06 & 6,50 & \multirow{2}{*}{0,149} \\
\hline & $\mathbf{I G}=\mathbf{1}$ & 2,628 & 0,849 & 1,53 & 4,50 & \\
\hline
\end{tabular}

* p-valor obtido pelo teste de Mann-Whitney

Nota: DP=Desvio-padrão 


\section{TABELA 12 - Coeficientes de Correlação de Spearman para as medidas observadas $(n=66)$}

\begin{tabular}{cr|c|c|c|c}
\hline \multirow{2}{*}{$\begin{array}{c}\text { Medidas } \\
\text { observadas }\end{array}$} & & \multicolumn{4}{|c}{ Medidas } \\
\cline { 3 - 6 } & Correlação & 1 & 0,066 & $\mathbf{0 , 3 6 6}$ & $\mathbf{0 , 2 8 0}$ \\
Profundidade & p-valor & & 0,601 & 0,003 & 0,023 \\
\hline de sondagem (PS) & Correlação & 0,066 & 1 & $\mathbf{0 , 4 0 3}$ & 0,205 \\
\hline $\begin{array}{c}\text { Largura da mucosa } \\
\text { ceratinizada (MC-l) }\end{array}$ & p-valor & 0,601 & & 0,001 & 0,100 \\
\hline $\begin{array}{c}\text { Espessura da mucosa } \\
\text { ceratinizada (MC-e) }\end{array}$ & Correlação & $\mathbf{0 , 3 6 6}$ & $\mathbf{0 , 4 0 3}$ & 1 & 0,203 \\
\hline $\begin{array}{c}\text { Dist. da margem gengival } \\
\text { à crista óssea (MG-COalor }\end{array}$ & Correlação & 0,003 & 0,001 & & 0,101 \\
\hline
\end{tabular}

Nota: os valores em vermelho representam correlações estatisticamente significaticas $(\mathrm{p}<0,05)$; os em azul, altamente significativas $(\mathrm{p}<0,01)$ 


\section{TABELA 13 - Coeficientes de Correlação de Spearman para as medidas observadas segundo os grupos de dentes}

\begin{tabular}{|c|c|c|c|c|c|c|}
\hline \multirow{2}{*}{$\begin{array}{l}\text { Grupo de } \\
\text { dentes }\end{array}$} & \multirow{2}{*}{\multicolumn{2}{|c|}{$\begin{array}{c}\text { Medidas } \\
\text { observadas }\end{array}$}} & \multicolumn{4}{|c|}{ Medidas } \\
\hline & & & PS & MC-I & MC-e & MG-CO \\
\hline \multirow{8}{*}{$\begin{array}{c}\text { Incisivos } \\
\text { e } \\
\text { caninos } \\
(n=36)\end{array}$} & \multirow{2}{*}{$\begin{array}{c}\text { Profundidade } \\
\text { de sondagem (PS) }\end{array}$} & Correlação & 1 & 0,296 & 0,250 & 0,658 \\
\hline & & p-valor & & 0,080 & 0,142 & $<0,001$ \\
\hline & \multirow{2}{*}{$\begin{array}{l}\text { Largura da mucosa } \\
\text { ceratinizada (MC-I) }\end{array}$} & Correlação & 0,296 & 1 & 0,440 & 0,255 \\
\hline & & p-valor & 0,080 & & 0,007 & 0,133 \\
\hline & \multirow{2}{*}{$\begin{array}{l}\text { Espessura da mucosa } \\
\text { ceratinizada (MC-e) }\end{array}$} & Correlação & 0,250 & 0,440 & 1 & 0,278 \\
\hline & & p-valor & 0,142 & 0,007 & & 0,100 \\
\hline & \multirow{2}{*}{$\begin{array}{l}\text { Dist. da margem gengival } \\
\text { à crista óssea (MG-CO) }\end{array}$} & Correlação & 0,658 & 0,255 & 0,278 & 1 \\
\hline & & p-valor & $<0,001$ & 0,133 & 0,100 & \\
\hline \multirow{8}{*}{$\begin{array}{c}\text { Pré-molares } \\
\text { e } \\
\text { molares } \\
(n=30)\end{array}$} & \multirow{2}{*}{$\begin{array}{c}\text { Profundidade } \\
\text { de sondagem (PS) }\end{array}$} & Correlação & 1 & $-0,052$ & 0,502 & $-0,006$ \\
\hline & & p-valor & & 0,783 & 0,005 & 0,975 \\
\hline & \multirow{2}{*}{$\begin{array}{l}\text { Largura da mucosa } \\
\text { ceratinizada (MC-I) }\end{array}$} & Correlação & $-0,052$ & 1 & 0,442 & $-0,082$ \\
\hline & & p-valor & 0,783 & & 0,014 & 0,666 \\
\hline & \multirow{2}{*}{$\begin{array}{l}\text { Espessura da mucosa } \\
\text { ceratinizada (MC-e) }\end{array}$} & Correlação & $\mathbf{0 , 5 0 2}$ & 0,442 & 1 & 0,127 \\
\hline & & p-valor & 0,005 & 0,014 & & 0,502 \\
\hline & \multirow{2}{*}{$\begin{array}{l}\text { Dist. da margem gengival } \\
\text { à crista óssea (MG-CO) }\end{array}$} & Correlação & $-0,006$ & $-0,082$ & 0,127 & 1 \\
\hline & & p-valor & 0,975 & 0,666 & 0,502 & \\
\hline
\end{tabular}

Nota: os valores em vermelho representam correlações estatisticamente significaticas $(\mathrm{p}<0,05)$; os em azul, altamente significativas $(\mathrm{p}<0,01)$ 


\section{TABELA 14 - Coeficientes de Correlação de Spearman para as medidas observadas segundo a espessura óssea}

\begin{tabular}{|c|c|c|c|c|c|c|}
\hline \multirow{2}{*}{$\begin{array}{c}\text { Espessura } \\
\text { óssea }\end{array}$} & \multirow{2}{*}{\multicolumn{2}{|c|}{$\begin{array}{c}\text { Medidas } \\
\text { observadas }\end{array}$}} & \multicolumn{4}{|c|}{ Medidas } \\
\hline & & & \multirow{3}{*}{$\begin{array}{c}\text { PS } \\
1\end{array}$} & \multirow{3}{*}{$\begin{array}{c}\text { MC-I } \\
0,127 \\
0,627\end{array}$} & \multirow{3}{*}{\begin{tabular}{|c|} 
MC-e \\
0,108 \\
0,679 \\
\end{tabular}} & \multirow{3}{*}{\begin{tabular}{|c|} 
MG-CO \\
0,282 \\
0,273
\end{tabular}} \\
\hline \multirow{8}{*}{$\begin{array}{c}\text { Fina } \\
(n=17)\end{array}$} & Profundidade & Correlação & & & & \\
\hline & de sondagem $(\mathbf{P S})$ & p-valor & & & & \\
\hline & Largura da mucosa & Correlação & 0,127 & 1 & 0,584 & 0,356 \\
\hline & ceratinizada (MC-1) & p-valor & 0,627 & & 0,014 & 0,161 \\
\hline & Espessura da mucosa & Correlação & 0,108 & 0,584 & 1 & 0,279 \\
\hline & ceratinizada (MC-e) & p-valor & 0,679 & 0,014 & & 0,278 \\
\hline & Dist. da margem gengival & Correlação & 0,282 & 0,356 & 0,279 & 1 \\
\hline & à crista óssea (MG-CO) & p-valor & 0,273 & 0,161 & 0,278 & \\
\hline \multirow{8}{*}{$\begin{array}{c}\text { Normal } \\
(n=36)\end{array}$} & Profundidade & Correlação & $\overline{1} 1$ & 0,258 & 0,368 & 0,431 \\
\hline & de sondagem $(\mathbf{P S})$ & p-valor & & 0,129 & 0,027 & 0,009 \\
\hline & Largura da mucosa & Correlação & 0,258 & 1 & 0,470 & 0,356 \\
\hline & ceratinizada $(\mathbf{M C}-\mathbf{l})$ & p-valor & 0,129 & & 0,004 & 0,033 \\
\hline & Espessura da mucosa & Correlação & 0,368 & 0,470 & 1 & 0,186 \\
\hline & ceratinizada (MC-e) & p-valor & 0,027 & 0,004 & & 0,276 \\
\hline & Dist. da margem gengival & Correlação & 0,431 & 0,356 & 0,186 & 1 \\
\hline & à crista óssea (MG-CO) & p-valor & 0,009 & 0,033 & 0,276 & \\
\hline \multirow{8}{*}{$\begin{array}{c}\text { Grossa } \\
(n=13)\end{array}$} & Profundidade & Correlação & 1 & $-0,593$ & 0,639 & $-0,015$ \\
\hline & de sondagem $(\mathbf{P S})$ & p-valor & & 0,033 & 0,019 & 0,961 \\
\hline & Largura da mucosa & Correlação & $-0,593$ & 1 & $-0,235$ & $-0,121$ \\
\hline & ceratinizada (MC-I) & p-valor & 0,033 & & 0,440 & 0,694 \\
\hline & Espessura da mucosa & Correlação & 0,639 & $-0,235$ & 1 & 0,285 \\
\hline & ceratinizada (MC-e) & p-valor & 0,019 & 0,440 & & 0,346 \\
\hline & Dist. da margem gengival & Correlação & $-0,015$ & $-0,121$ & 0,285 & 1 \\
\hline & à crista óssea (MG-CO) & p-valor & 0,961 & 0,694 & 0,346 & \\
\hline
\end{tabular}

Nota: os valores em vermelho representam correlações estatisticamente significaticas $(\mathfrak{b}<0.05)$ : os em azul. altamente significativas $(\mathfrak{b}<0.01)$ 


\section{TABELA 15 - Coeficientes de Correlação de Spearman para as medidas observadas segundo o índice de sangramento gengival}

\begin{tabular}{|c|c|c|c|c|c|c|}
\hline \multirow{2}{*}{$\begin{array}{c}\text { Índice de sangramento } \\
\text { gengival }\end{array}$} & \multirow{2}{*}{\multicolumn{2}{|c|}{$\begin{array}{l}\text { Medidas } \\
\text { observadas }\end{array}$}} & \multicolumn{4}{|c|}{ Medidas } \\
\hline & & & \multirow{3}{*}{$\frac{\text { PS }}{1}$} & \multirow{3}{*}{$\begin{array}{c}\text { MC-I } \\
0,121 \\
0,404\end{array}$} & \multirow{3}{*}{$\begin{array}{c}\text { MC-e } \\
\mathbf{0 , 5 1 6} \\
<0,001\end{array}$} & \multirow{3}{*}{$\begin{array}{c}\text { MG-CO } \\
0,223 \\
0,120\end{array}$} \\
\hline \multirow{8}{*}{$\begin{array}{c}\text { ISG }=0 \\
(n=50)\end{array}$} & \multirow{2}{*}{$\begin{array}{c}\text { Profundidade } \\
\text { de sondagem (PS) }\end{array}$} & Correlação & & & & \\
\hline & & p-valor & & & & \\
\hline & \multirow{2}{*}{$\begin{array}{l}\text { Largura da mucosa } \\
\text { ceratinizada (MC-I) }\end{array}$} & Correlação & 0,121 & 1 & 0,385 & 0,219 \\
\hline & & p-valor & 0,404 & & 0,006 & 0,126 \\
\hline & \multirow{2}{*}{$\begin{array}{l}\text { Espessura da mucosa } \\
\text { ceratinizada (MC-e) }\end{array}$} & Correlação & 0,516 & 0,385 & 1 & 0,198 \\
\hline & & p-valor & $<0,001$ & 0,006 & & 0,169 \\
\hline & \multirow{2}{*}{$\begin{array}{l}\text { Dist. da margem gengival } \\
\text { à crista óssea (MG-CO) }\end{array}$} & Correlação & 0,223 & 0,219 & 0,198 & \multirow[t]{2}{*}{1} \\
\hline & & p-valor & 0,120 & 0,126 & 0,169 & \\
\hline \multirow{8}{*}{$\begin{array}{c}\text { ISG }=1 \\
(n=16)\end{array}$} & \multirow{2}{*}{$\begin{array}{c}\text { Profundidade } \\
\text { de sondagem }(\mathbf{P S})\end{array}$} & Correlação & 1 & $-0,153$ & $-0,084$ & 0,235 \\
\hline & & p-valor & & 0,571 & 0,758 & 0,381 \\
\hline & \multirow{2}{*}{$\begin{array}{l}\text { Largura da mucosa } \\
\text { ceratinizada (MC-l) }\end{array}$} & Correlação & $-0,153$ & 1 & 0,475 & 0,218 \\
\hline & & p-valor & 0,571 & & 0,063 & 0,418 \\
\hline & \multirow{2}{*}{$\begin{array}{l}\text { Espessura da mucosa } \\
\text { ceratinizada (MC-e) }\end{array}$} & Correlação & $-0,084$ & 0,475 & 1 & 0,232 \\
\hline & & p-valor & 0,758 & 0,063 & & 0,388 \\
\hline & \multirow{2}{*}{$\begin{array}{l}\text { Dist. da margem gengival } \\
\text { à crista óssea (MG-CO) }\end{array}$} & Correlação & 0,235 & 0,218 & 0,232 & \multirow[t]{2}{*}{1} \\
\hline & & p-valor & 0,381 & 0,418 & 0,388 & \\
\hline
\end{tabular}

Nota: os valores em vermelho representam correlações estatisticamente significaticas $(\mathrm{p}<0,05)$; os em azul, altamente significativas $(\mathrm{p}<0,01)$ 


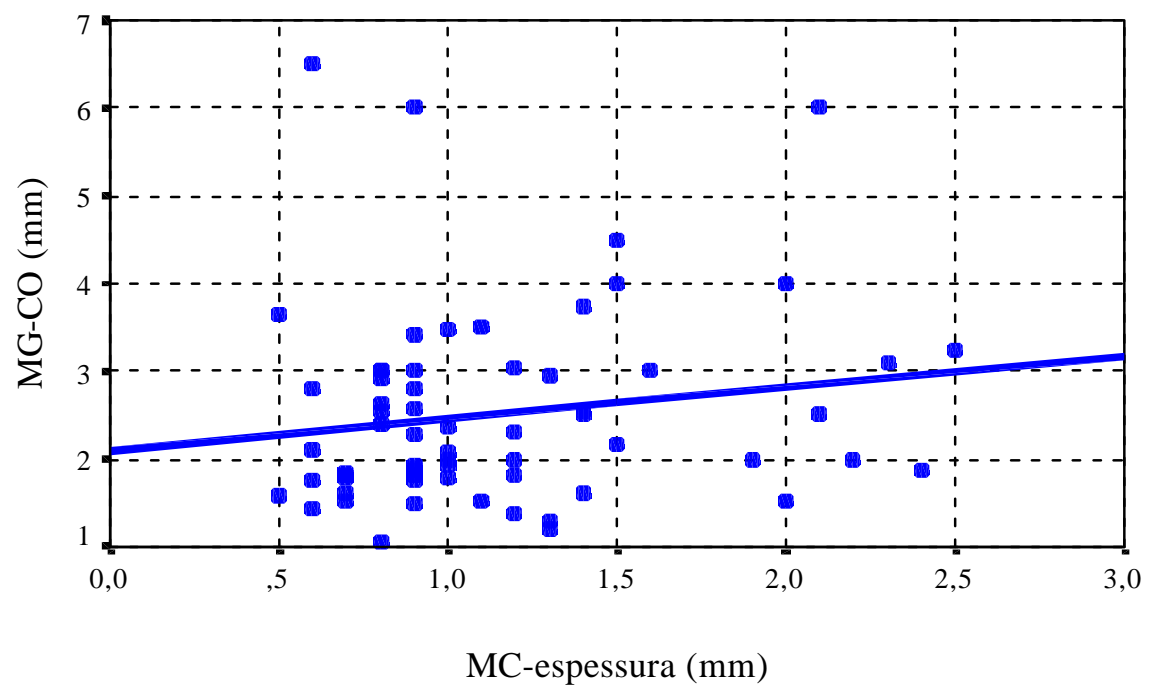

Coef. de correlação de Spearman $=0,203$

FIGURA 30 - Distância da margem gengival à crista óssea segundo a espessura da mucosa ceratinizada

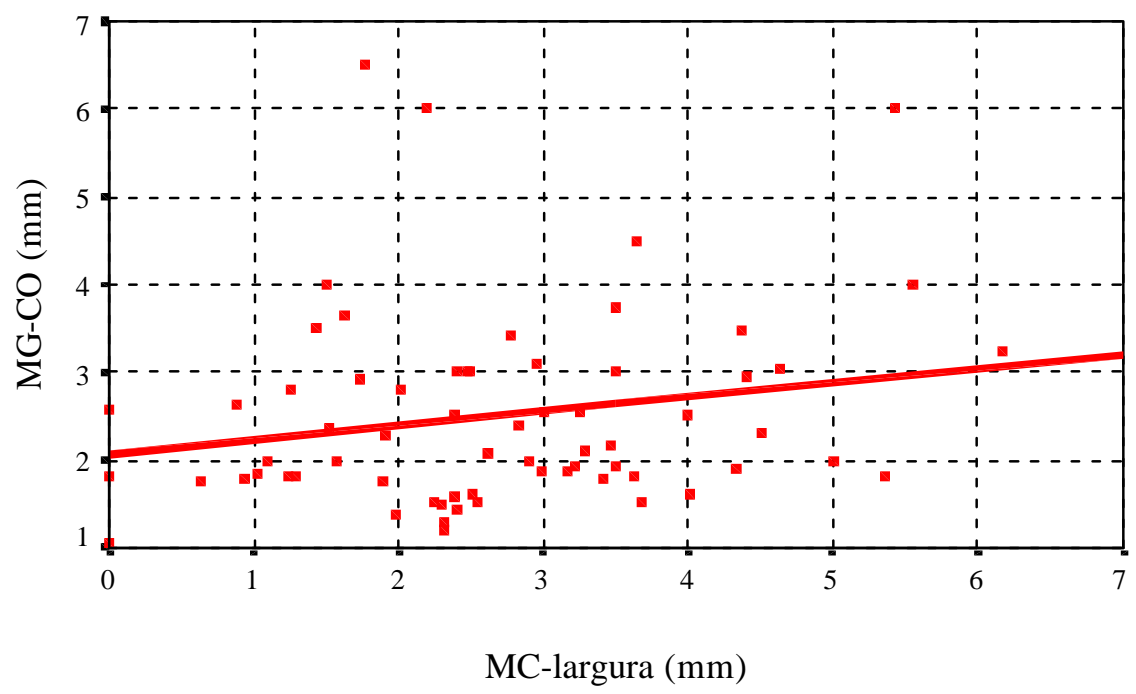

Coef. de correlação de Spearman $=0,205$

FIGURA 31 - Distância da margem gengival à crista óssea segundo a largura da mucosa ceratinizada 


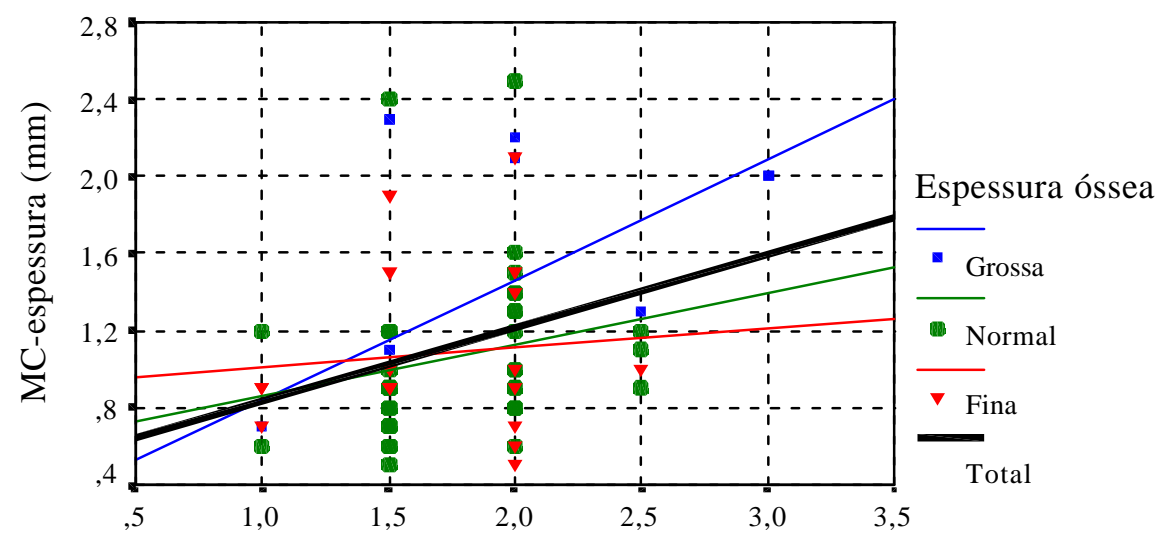

Profundidade de sondagem (mm)

Coeficientes de correlação de Spearman:

Total $=0,366 ;$ Fina $=0,108 ;$ Normal $=0,368 ;$ Grossa $=0,639$

\section{FIGURA 32 - Espessura da mucosa ceratinizada segundo profundidade de sondagem}

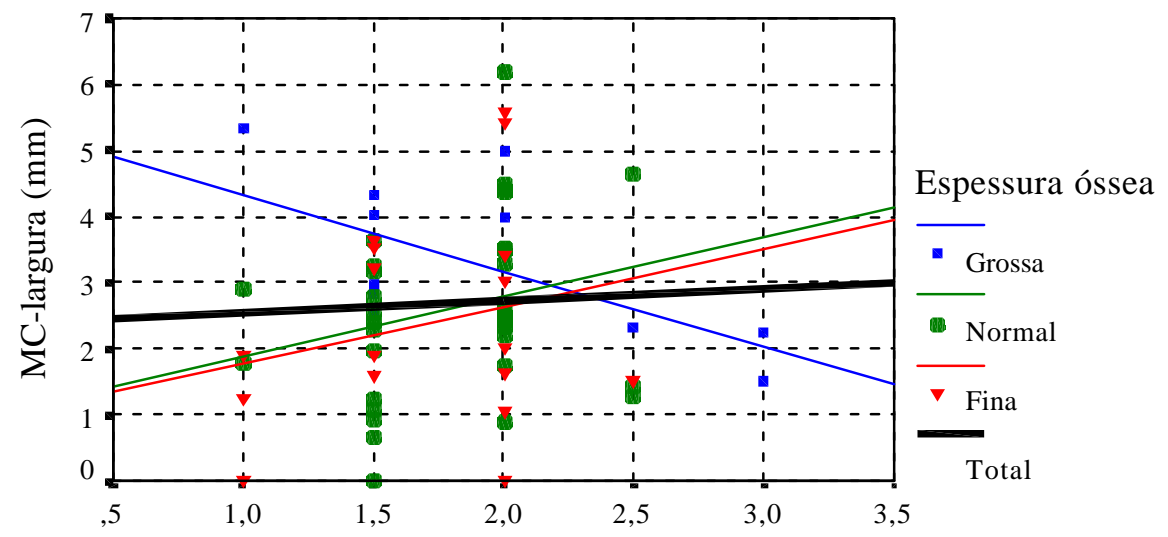

Profundidade de s ondagem (mm)

Coeficientes de correlação de Spearman:

Total $=0,066 ;$ Fina $=0,127 ;$ Normal $=0,258 ;$ Grossa $=-0,593$

FIGURA 33 - Largura da mucosa ceratinizada segundo a profundidade de sondagem 
6 DISCUSSÃO 


\section{DISCUSSÃO}

Muitos equipamentos têm sido utilizados para a análise e controle dos níveis de inserção e a mensuração das distâncias biológicas. Dentre eles, os mais comumente utilizados na clínica cotidiana e periodontal são praticamente os mesmos de muitos anos, ou seja, a sonda periodontal e a radiografia periapical.

Apesar da busca tecnológica intensa de prevenção da doença periodontal, que resultou numa diminuição considerável da sua prevalência, a capacidade previsora de perda de inserção periodontal nos pacientes ainda é praticamente nula. As sondas periodontais foram sofisticadas com o surgimento dos equipamentos de pressão controlada e os exames imaginológicos de diagnóstico hoje se encontram na era da informática, com técnicas de radiografias digitais com recursos de contraste e nitidez muito superiores às películas radiográficas convencionais, embora pouco presentes na clínica do clínico geral.

O que se pode perceber é que os avanços estão mais concentrados nos tratamentos curativos, ou seja, de proceder o reparo das lesões ósseas periodontais resultantes de processos imunológicos e/ou inflamatórios tais como: enxertos ósseos aloplásticos, enxertos ósseos alógenos, enxertos ósseos xenógenos, enxertos ósseos autógenos, barreiras mecânicas reabsorvíveis ou não, fatores de crescimento e outros.

A anatomia dos tecidos periodontais marginais apresentam variações funcionais entre indivíduos e até mesmo em um mesmo indivíduo. A quantidade e qualidade teciduais podem determinar sobremaneira a 
homeostasia deste periodonto, podendo promover alterações importantes que poderão comprometer o elemento em questão a médio e longo prazo.

A multifatoriedade da etiologia da doença periodontal faz com que seu diagnóstico e tratamento seja um dos maiores desafios apresentados nas diversas doenças que afligem a humanidade. As variáveis são tantas que é praticamente impossível, com os recursos disponíveis, conduzir um plano de tratamento inteiramente confiável e previsível.

Portanto, é extremamente importante uma melhor caracterização clínica dos fatores biológicos relacionados com o comportamento normal dos tecidos, feita através de métodos menos invasivos, de modo a permitir melhor abordagem preventiva e até curativa da doença periodontal marginal infecciosa.

Um dos mais importantes parâmetros para a previsibilidade da manutenção da homeostasia do periodonto se encontra na verificação da normalidade clínica gengival. O que é considerado normal? Elementos dentais com conteúdo de colágeno extremamente deficiente muitas vezes não apresentam perda de inserção associadas ou não com recessões gengivais, enquanto que áreas com tecido gengival fibrótico e ausência clínica aparente de inflamação apresentam perdas ósseas significativas (observadas nas periodontites de aparecimento precoce). Entretanto, ao se conduzir tratamento clínico, é mister controlar o que está ao alcance, ou seja, características da mucosa ceratinizada, periodonto marginal com sulco clínico raso e manifestação do comportamento fisiológico do sulco gengival, com ausência de fatores etiológicos primários e secundários locais visíveis que pudessem comprometer a capacidade deste periodonto de controlar os agentes agressores. Por isso, dentro da metodologia proposta, objetivou-se o estudo das características gengivais de espessura e largura. 
A detecção da espessura da mucosa marginal (MC-e) evidentemente requereria a abertura cirúrgica do retalho, porém o surgimento de um sonar para análise de espessura tecidual (SDM) possibilitou a verificação da espessura gengival de forma bastante rápida, a ponto de permitir um verdadeiro mapeamento do tecido mole com uma técnica não invasiva.

Uma faixa mínima de $2 \mathrm{~mm}$ de mucosa ceratinizada detectada no estudo clássico de LANG; LÖE ${ }^{21}$ (1972) foi proposto como necessária para manifestação de saúde periodontal, sendo, portando, importante a sua definição. Esta faixa pode ser facilmente examinada com o uso da sonda periodontal, assim como o seria pelo teste de Bowers, por ser de simples execução. Entretanto, para a análise precisa da faixa de mucosa ceratinizada (MC-1) (margem gengival-junção mucogengival) foi utilizado nesta pesquisa um paquímetro eletrônico de maneira a realizar a medição da forma mais exata possível.

Para análise da profundidade de sondagem clínica (PS), está disponível um instrumento com alta sensibilidade (possibilidade de um teste dar positivo na presença de doença - no caso: perda de inserção) - a sonda periodontal.

O Índice de Sangramento Gengival (ISG) é um parâmetro de também fácil detecção, por se tratar de um procedimento não invasivo e de fácil manuseio, servindo para caracterizar o comportamento do sulco gengival.

Para complementar o trabalho e realizar o cruzamento de dados para análise das distâncias biológicas, foi observada a espessura óssea marginal(EO) de dentes adjacentes a áreas edêntulas, aproveitando o 
levantamento de retalho mucoperiósteo para fixação de implantes dentais osseointegrados

Apenas para efeito didático, a discussão dos resultados foi subdividida em três partes:

1) Parte I: Parte descritiva ou exploratória com a finalidade de caracterizar a amostra

2) Parte II: Análise da associação das variáveis estudadas

3) Parte III: Análise global 


\subsection{PARTE I: PARTE DESCRITIVA OU EXPORATÓRIA (CARACTERIZAÇÃO DA AMOSTRA)}

De acordo com a tabela 1 e figura 20, pode-se observar que foram utilizados 17 incisivos ou 25,8\%; 19 caninos ou 28,8\%; 22 prémolares ou $33,3 \%$ e 8 molares ou $12,1 \%$ dos elementos dentais. Desse modo procurou-se realizar uma abordagem que pudesse caracterizar tanto os dentes anteriores quanto os posteriores.

De acordo com a tabela 2, foram encontradas profundidades de sondagens (PS) mínimas de 1,0mm e máximas de 3,0mm com um desvio padrão de $0,44 \mathrm{~mm}$ e valores médios de $1,78 \mathrm{~mm}$ com tendência de produzir ligeiro aumento da profundidade de sondagem com aumento da espessura óssea e da largura da mucosa ceratinizada (Tabela 10).

A largura de mucosa ceratinizada (MC-1) teve valores mínimos de 0 , ou seja, ausência desse tipo de mucosa, largura máxima de 6,17mm com um desvio-padrão de $1,372 \mathrm{~mm}$ e valores médios de $2,87 \mathrm{~mm}$, enquanto a espessura de mucosa ceratinizada (MC-e) apresentou espessura mínima de 0,5mm, e máxima de 2,5mm, com um desvio-padrão de $0,49 \mathrm{~mm}$ e uma média para todos os sítios de $1,13 \mathrm{~mm}$.

A distância da margem gengival à crista óssea (MG-CO), ou seja, o espaço preconizado para conter as distâncias biológicas preconizadas por GARGIULO ${ }^{13}$ em 1961, apresentaram uma média ligeiramente inferior a $2.73 \mathrm{~mm}$ encontrada pelo autor, ficando na casa dos 2,507mm. Apresentou um valor mínimo de $1.06 \mathrm{~mm}$ e um máximo de $6,50 \mathrm{~mm}$ com um desvio padrão de $1,107 \mathrm{~mm}$.

Ao analisar as estatíticas descritivas das medidas observadas segundo o grupo dos dentes (Tabela 3), pode evidenciar que a profundidade de sondagem (PS) apresenta diferença sutil entre o grupo de incisivos e 
caninos e o grupo de pré-molares e molares, com $1,72 \mathrm{~mm}$ e $1,85 \mathrm{~mm}$ respectivamente. Quando se relaciona a espessura da mucosa ceratinizada (MC-e) entre os dois grupos (I e C X PM e M), obtêm-se medidas quase iguais, com média de 1,15mm para os incisivos/caninos e 1,11mm para prémolares/molares.

No que se refere à distância da margem gengival-crista óssea (MG-CO), os valores encontrados para os grupos são espelhados na média de incisivos e caninos de $2,695 \mathrm{~mm}$ e na de pré-molares e molares que foi de 2,282mm, dando uma diferença que apresentou $\mathrm{p}=0,025$, o que é estatisticamente significativo. Esses resultados são indicativos que as distâncias biológicas nos dentes anteriores são maiores, em média, do que nos dentes posteriores.

Outro dado de grande importância foi a diferença encontrada para as médias de incisivos e caninos de $3,175 \mathrm{~mm}$ em contrapartida para as médias de pré-molares e molares que foi de 2,1mm no quesito largura da mucosa ceratinizada (MC-1). O p-valor obtido pelo teste de Mann-Whitney foi $\mathrm{p}=0,001$, o que é altamente significativo.

$\mathrm{Na}$ tabela 4 e figura 25 pode-se observar a distribuição dos dentes segundo o Índice de Sangramento Gengival(ISG) dicotômico preconizado por MUHLEMANN; $\mathrm{SON}^{33}$, 1971. Cinquenta dentes apresentaram ISG $=0$, ou seja 75,8\% dos elementos medidos, enquanto 16 dentes ou $24,2 \%$ apresentaram $\mathrm{ISG}=1$.

Fazendo uma análise na tabela 5 e figura 26 para índice gengival (ISG) segundo grupos de dentes, pode-se denotar que o grupo de incisivos e caninos parecem apresentar condição homeostática superior ao grupo de pré-molares e molares, com $\mathrm{ISG}=0$ de $83,3 \%$ contra $66,7 \%$ e ISG $=1$ de $16,7 \%$ contra $33,3 \%$. Um interessante resultado no confronto de 
dentes com (ISG) Índice de Sangramento Gengival = 0 (ISG=0) e Índice de Sangramento Gengival $=1(\mathrm{ISG}=1)$ pôde ser observado na tabela 6 e no figura 27. Nos dentes onde não foram detectadas alterações gengivais $(\mathrm{IG}=0)$, crista óssea normal foi encontrada na maior porcentagem dos dentes analisados - 60\%. Os dentes com crista óssea (EO) fina ficaram em 16,0\% e $24 \%$ para crista óssea grossa. Em contrapartida, no grupo de dentes em que foram detectadas alterações gengivais $(\mathrm{IG}=1)$, a maior porcentagem foi encontrada no grupo de crista óssea fina - 56,3\%; com 37,5\% de crista óssea normal e apenas $6,3 \%$ de crista óssea grossa, sugerindo que crista óssea fina suporta tecido com conteúdo de colágeno mais frágil e condição homeostática pior. No teste $X^{2}$ (Quiquadrado) pode-se perceber um pvalor $=0,005$, ou seja, altamente significativo.

A espessura óssea (EO) apresentada está correlacionada na tabela 7 e figura 28 , com 17 dentes com espessura óssea marginal fina ou 25,8\%, 36 dentes com espessura óssea marginal normal ou 54,5\% e 13 dentes com espessura óssea marginal grossa ou 19,7\% dos elementos dentais da amostra. Esse aspecto parece espelhar a validade da classificação empregada para distribuição da espessura óssea nos espécimes estudados, pois é de se esperar que situações normais sejam mais prevalentes.

$\mathrm{Na}$ tabela 8 foram observadas as espessuras ósseas(EO) separadamente segundo o tipo de dente. Nos incisivos, 5,9\% apresentaram espessura óssea fina; 70,6\% espessura óssea normal e 23,5\% espessura óssea engrossada. Nos caninos, 26,3\% apresentaram espessura óssea fina; 57,9\% espessura óssea normal e 15,8\% espessura óssea engrossada. Nos prémolares, 45,5\% apresentaram espessura óssea fina; 45,5\% espessura óssea normal e 9,1\% espessura óssea engrossada. Nos molares, 12,5\% 
apresentaram espessura óssea fina; 37,5\% espessura óssea normal e 50\% espessura óssea engrossada.

Deste universo, pode-se notar que somente nos molares a maioria (metade) apresentou espessura óssea engrossada, enquanto que nos incisivos, caninos e pré-molares a maior porcentagem se concentrou na espessura óssea normal, ressaltando-se, porém prevalência relativamente alta de espessura fina, principalmente e pela ordem decrescente nos pré-molares, caninos e molares.

$\mathrm{Na}$ tabela 9 e figura 29, pode-se observar a espessura óssea segundo o grupo de dentes. Nos incisivos e caninos houve grande discrepância em relação à maior porcentagem para a crista óssea normal, que representou $63,9 \%$, seguida de $19,4 \%$ para crista óssea grossa e 16,7\% para crista fina. Já no grupo dos pré-molares e molares a distribuição não foi tão discrepante, havendo $36,7 \%$ de dentes com crista óssea fina, 43,3\% de dentes com crista óssea normal e $20 \%$ com crista óssea grossa.

A distribuição da espessura da mucosa ceratinizada (MC-e), representada pela figura 21 demonstra que os valores mais significativos se encontram de 0,7 a 1,0mm, com 26 dentes enquadrados nesta faixa.

A figura 22 apresenta a distribuição da largura da mucosa ceratinizada (MC-1), com intervalos de $0,5 \mathrm{~mm}$, iniciando de 0,00 a $0,5 \mathrm{~mm}$; 0,5 a $1,0 \mathrm{~mm} ; 1,0$ a $1,5 \mathrm{~mm}$ e assim sucessivamente. A faixa mais significativa desta distribuição se encontra de 1,5 a 3,0mm.

A figura 23 apresenta a distribuição da profundidade de sondagem (PS), podendo-se observar que a grande maioria dos sítios - 53\% - apresentam valores entre $1,5 \mathrm{a} 2 \mathrm{~mm}$.

Os valores mais expressivos para a distância da margem gengival-crista óssea (MG-CO) estão concentrados entre 1,5 a 2,0mm, 
segundo a figura 24. Do universo de 63 sítios, 23 se enquadraram nestes valores. Depois dessa faixa, a variação de $2,0 \mathrm{~mm}$ a $3,5 \mathrm{~mm}$ compõe o outro grupo significativo, com 29 sítios. 


\subsection{PARTE II: ANÁLISE DA ASSOCIAÇÃO DAS VARIÁVEIS ESTUDADAS}

Os coeficientes de correlação de Spearman para as medidas observadas na tabela 12, permitem analisar as medidas de profundidade de sondagem (PS), largura da mucosa ceratinizada (MC-1), espessura da mucosa ceratinizada (MC-e) e distância da margem gengival-crista óssea (MG-CO) entre si. Dentre todos os cruzamentos de informações, algumas delas se destacam por serem estatisticamente significantes e outras altamente significantes.

Assim, pode-se verificar correlação altamente significativa $(\mathrm{p}<0,003)$ entre a profundidade de sondagem (PS) e a espessura da mucosa ceratinizada (MC-e). Ainda na análise da profundidade de sondagem (PS), sua correlação com a distância da margem gengival-crista óssea (MG-CO) é estatisticamente significativa $(\mathrm{p}<0,023)$.

Ainda nesta análise, encontra-se correlação altamente significativa $(p<0,001)$ entre a largura da mucosa ceratinizada $(M C-1)$ e a espessura da mucosa ceratinizada (MC-e). Estes dados parecem ser interessantes, pois a correlação positiva entre a espessura e largura da mucosa ceratinizada definem a importância da qualidade e quantidade de gengiva ceratinizada.

As correlações apresentadas nesta tabela são de muita importância para decisões de cunho clínico, pois podem definir níveis de preparos cavitários sub-gengivais, previsibilidades estéticas pré-protéticas e outros.

Também foi feita a análise destes coeficientes de correlação de Spearman para todas as medidas analisadas anteriormente, desta vez por grupos de dentes (tabela 13). Para os incisivos e caninos, existe correlação 
altamente significativa $(\mathrm{p}<0,001)$ entre a profundidade de sondagem (PS) e a distância da margem gengival à crista óssea (MG-CO). Esta correlação também se mostra altamente significativa $(\mathrm{p}<0,007)$ quando se correlaciona a largura da mucosa ceratinizada (MC-1) com a espessura da mucosa ceratinizada (MC-e). Pode-se notar que, ao contrário da análise geral de todos os dentes, não houve correlação estatisticamente significativa entre a profundidade de sondagem (PS) e espessura de mucosa ceratinizada (MC-e) para os dentes anteriores, enquanto que nos pré-molares e molares, essa correlação foi altamente significativa $(\mathrm{p}<0,005)$. Isso talvez pudesse ser dependente do fato das pessoas praticarem mais assiduamente e mais eficazmente o controle de placa dentobacteriana nos dentes anteriores.

Veja-se, por exemplo, que AINAMO, LÖE ${ }^{4}$, et al. propuseram não haver diferenças significativas do comportamento periodontal marginal em áreas com e sem quantidade adequada de gengiva ceratinizada, desde que se mantenha bom controle de placa dentobacteriana.

Entretanto, pode-se evidenciar correlação estatisticamente significante $(p<0,014)$ entre a largura $(M C-1)$ e espessura $(M C-e)$ da mucosa ceratinizada que, nos dentes anteriores se apresenta altamente significante.

$\mathrm{Na}$ análise das observações baseadas no parâmetro Índice de Sangramento Gengival (ISG) na tabela 11, pode-se perceber uma diferença sutil na profundidade de sondagem (PS). Para ISG=0, houve média de $1,75 \mathrm{~mm}$, enquanto que, para $\mathrm{ISG}=1$, a média foi de $1,88 \mathrm{~mm}$, portanto ligeiramente superior. $\mathrm{Na}$ análise da distância da margem gengival-crista óssea (MG-CO), as médias encontradas $(2,468 \mathrm{~mm})$ para $\mathrm{ISG}=0$ foram também ligeiramente menores do que para $\mathrm{ISG}=1(2,628 \mathrm{~mm})$. Isto talvez possa ser devido ao ligeiro edema (sub-clínico) encontrado na margem gengival nos casos em questão. 
$\mathrm{Na}$ tabela 15 são apresentados os resultados das análises cruzadas, tomando como base o Índice de Sangramento Gengival (ISG) dicotômico. Quando $\mathrm{ISG}=1$, não foi encontrada nenhuma correlação significativa entre os valores anatômicos, porém, quando o ISG=0 duas correlações altamente significativas estatisticamente existem, todas relacionadas com a espessura da mucosa ceratinizada (MC-e): a correlação com a profundidade de sondagem (PS) (correlação de Spearman $=0,516$ / pvalor<0,001) e com a largura da mucosa ceratinizada (MC-1) (correlação de Spearman $=0,385 /$ p-valor $=0,006)$.

Quando o enfoque da análise é a espessura da crista óssea (EO) (Tabela 10), apesar de não serem valores estatisticamente significantes, resultados interessantes podem ser observados:

a) Quanto maior a espessura óssea (EO), maior a profundidade de sondagem clínica (PS) observada pelas médias;

b) Quanto maior a espessura óssea (EO), maior a largura da mucosa ceratinizada (MC-1) o que foi observada pelas médias;

c) Os elementos com crista óssea grossa (EO) apresentaram maior espessura da mucosa ceratinizada (MC-e). As medidas observadas na espessura da mucosa (MC-e) entre a crista óssea normal e fina (EO) foram iguais;

d) A distância da margem gengival à crista óssea (MG-CO) foi inversamente proporcional à espessura óssea (EO), também observada pelas médias.

Na tabela 14, a análise dos coeficientes de correlação de Spearmman para todas as medidas com base na espessura óssea (EO), mostra diferenças interessantes para os três tipos. Quando se analisa dentes 
crista óssea fina, pode-se observar correlação estatisticamente significativa entre a largura da mucosa ceratinizada (MC-1) e a espessura da mucosa ceratinizada (MC-e) com $\mathrm{p}<0,014$. Interessante lembrar que, quanto mais o valor se aproxima de 1, mais verdadeira é a correlação (se analisar o cruzamento dos dados de Profundidade de Sondagem com Profundidade de sondagem, por exemplo, o valor desta correlação é $=1$, e o p-valor é $=0$ ). $\mathrm{Na}$ análise da espessura óssea (EO) normal com todos os outros valores, observa-se correlação estatisticamente significativa $(0,368 /$ p-valor=0,027) entre a profundidade de sondagem (PS) e a espessura da mucosa ceratinizada (MC-e) e correlação altamente significativa $(0,431 / \mathrm{p}$-valor $=0,009)$ entre a profundidade de sondagem (PS) e a distância da margem gengival-crista óssea (MG-CO). Quando se examina o quesito largura da mucosa ceratinizada (MC-1), a correlação com sua espessura (MC-e) é também altamente significativa $(0,470 / \mathrm{p}$-valor=0,004). Embora apenas estatisticamente significativa, esta correlação entre largura da mucosa ceratinizada (MC-1) e distância da margem gengival-crista óssea (MG-CO) também existe.

Nos sítios com espessura óssea grossa (EO), existem duas correlações distintas associadas com a profundidade de sondagem (PS) e a largura $(\mathrm{MC}-1)$ e espessura $(\mathrm{MC}-\mathrm{e})$ da mucosa ceratinizada. Em relação à largura (MC-1), pode-se observar que a correlação apresenta valor negativo $(-0,593)$ com $\mathrm{p}$-valor 0,033 (estatisticamente significativo). Isto significa que, quanto maior um valor, menor o outro, ou seja, quanto maior a profundidade de sondagem (PS), menor a largura da mucosa ceratinizada (MC-1). Quando se observa a espessura da mucosa ceratinizada (MC-e) encontra-se valor de correlação positivo $=0,639$ (com um $\mathrm{p}$-valor=0,019), 
ou seja, quanto maior a profundidade de sondagem (PS), maior a espessura da mucosa ceratinizada (MC-e) (estatisticamente significante)

Para finalizar esta parte da discussão, é apresentada a seguir análise das figuras de dispersão (30, 31, 32 e 33). As figuras 30, 31 e 33 mostram a tendência (porém fracas) de correlação positiva entre valores. Os coeficientes de correlação de Spearman não são estatisticamente significantes, mas são interessantes de ser observados.

Na figura 31, tem-se tendência positiva de variação da distância da margem gengival-crista óssea (MG-CO) em função da largura da mucosa ceratinizada (MC-1). Na figura 30, esta mesma tendência, apesar de fraca, também pode ser observada em relação à distância da margem gengivalcrista óssea (MG-CO) em função da espessura da mucosa ceratinizada (MCe).

A figura 32 exemplifica a forte correlação entre a espessura da mucosa ceratinizada (MC-e) segundo a profundidade de sondagem (PS) nas diferentes espessuras ósseas dos sítios. Excetuando-se a espessura óssea (EO) fina, todas as outras mostram forte tendência positiva de correlação, estatisticamente altamente significativas, que já foi abordada anteriormente e tida como uma das importantes observações deste trabalho.

$\mathrm{Na}$ figura 33 pode-se observar, como foi citado anteriormente, forte correlação negativa entre a largura da mucosa ceratinizada (MC-1) e a profundidade de sondagem (PS) quando a espessura óssea é grossa (exemplificado através da linha descendente de cor roxa), que se dilui com as outras correlações dos sítios de espessura óssea (EO) fina e normal quando observados através da tênue linha de cor negra ascendente (valor total). 


\subsection{PARTE III: ANÁLISE GLOBAL}

Uma análise global dos dados obtidos pareceu necessária tendo em vista a falta de informações na literatura disponível relativa às implicações anatômicas, biológicas e clínicas das diferentes interações processadas.

Assim, quando se analisou o volume gengival marginal pelo exame da distância da margem gengival à crista óssea, pôde-se constatar coerência da medida encontrada com aquela da largura da mucosa ceratinizada definida pelo instrumento de medição usado, pois esta $(2,687 \mathrm{~mm})$ foi maior do que aquela $(2,507 \mathrm{~mm})$.

Ressalte-se que o volume gengival marginal engloba as distâncias biológicas do periodonto marginal definidas por GARGIULO ${ }^{13}$ et al. em torno de 2,73mm, após a erupção total dos dentes, resultados, portanto, praticamente iguais aos desta pesquisa. A pequena variabilidade observada poderia estar relacionada principalmente ao fato de que esses autores mediram todas as faces dentais, além do que as mensurações foram feitas em secções obtidas de cadáveres. Veja-se que TARNOW; MAGNER; FLETCHER $^{49}$ propuseram que a gengiva interproximal pode alcançar até $5 \mathrm{~mm}$ coronalmente à crista óssea.

Além disso, a largura da mucosa ceratinizada apresentou-se maior nos dentes anteriores que posteriores, corroborando os resultados de AINAMO; LÖE $^{4}$ e aceitos por LÖE; LISTGARTEN; TERRANOVA ${ }^{28}$.

Fato interessante foi estreita correlação entre a largura (que se usa definir como quantidade da gengiva) e espessura da mucosa ceratinizada (tabelas 12 e 13). 
Embora essa correlação não tenha sido analisada literalmente, algumas especulações podem ser feitas a partir de análises apresentadas ${ }^{2^{*}}$.

Assim, quando um dente irrompe mais para lingual no rebordo alveolar, aumenta a largura da mucosa ceratinizada e a espessura da tábua óssea, de modo que cristas ósseas espessas associam-se com maior quantidade de gengiva ceratinizada.

Por outro lado, no presente trabalho observou-se que quanto maior a espessura óssea, maior a espessura da mucosa ceratinizada, de modo que parece aceitável considera-se a ocorrência de correlação positiva entre espessura óssea, largura e espessura da mucosa ceratinizada (Tabela 14).

Esses aspectos tornam-se relevantes quando se considera que a distância da margem gengival à crista óssea parece estar influenciada por essas correlações, de modo que parece aceitável considerar-se que as distâncias biológicas periodontais podem apresentar variações dimensionais em função da espessura óssea e a da qualidade e quantidade da gengiva ceratinizada.

Aliás, a variação das distâncias biológicas voltadas contra os dentes foi proposta por GARGIULO ${ }^{13}$ et al. e aceita por SCHLUGER $^{43}$ et al. Dessa forma, considerando que as distâncias biológicas periodontais parecem produzir proteção à crista óssea $\left(\mathrm{PASSANEZI}^{2 *}\right)$, como os resultados obtidos encontram-se dentro desses limites, quanto maior a espessura óssea, maior a largura e espessura da mucosa ceratinizada e, portanto, melhor a proteção óssea. Aliás, para RUBEN (apud PASSANEZI $^{1^{*}}$ ), a ocorrência de recessões gengivais é favorecida em áreas de septos ósseos finos, que se relacionaram com quantidade (pouca) e

\footnotetext{
${ }^{2}$ Comunicação pessoal
} 
qualidade (fina) inadequadas de gengiva ceratinizada, características essas correlacionadas positivamente neste trabalho (Tabelas 12, 13 e 14).

De modo geral, pôde-se também observar a ocorrência de correlação entre essas variáveis e a profundidade de sondagem do sulco gengival (tabelas 12, 13 e 14), também influenciada pela distância da margem gengival à crista óssea. A largura e espessura da mucosa ceratinizada e a distância da crista óssea à margem gengival relacionaram-se de maneira proporcional à profundidade de sondagem, indicando que um fator crítico pode se estabelecer na área marginal, favorecendo a formação de placa dentobacteriana, ou pondo em risco a integridade óssea por variação das distâncias biológicas do periodonto marginal, gerando maior profundidade do sulco gengival.

Isso talvez pudesse ser explicado pelo fato de que, estando a margem gengival mais para coronal e sendo a área de inserção conjuntiva constante (GARGIULO ${ }^{13}$ et al.), é de se esperar que tenha aumentado a região que engloba a área do sulco gengival e do epitélio juncional, refletindo-se em aumento da profundidade de sondagem do sulco gengival.

Por sua vez, o aumento da espessura óssea gera tendência de aumento da profundidade do sulco gengival (Tabela 10), o que parece sugestivo de que o aumento da espessura óssea conduz a margem gengival mais para coronal. Como a área de inserção conjuntiva apresenta-se com maior estabilidade dimensional (GARGIULO ${ }^{13}$ et al.), parece aceitável considerar-se que possa ter havido aumento da profundidade de sondagem.

De qualquer maneira essas variáveis podem tornar crítico o comportamento fisiológico do sulco gengival, pois parece estar bem sedimentado o conceito de que a invasão das distâncias biológicas periodontais conduz à reabsorção óssea, com formação de bolsa se a gengiva 
for espessa, ou recessão gengival se fina (PASSANEZI ${ }^{39}$ et al.; TARNOW; STHAL; MAGNER; ZAMZOK ${ }^{50}$ ).

Outros achados importantes relacionaram-se aos resultados do Índice de Sangramento Gengival, que, em última análise, foi significativo nos casos de aumento da profundidade de exploração do sulco gengival, de diminuição da largura da mucosa ceratinizada e diminuição da espessura da crista óssea (Tabela 9, Figura 29, Tabela 11).

Como a diminuição da espessura da crista óssea está mais associada à diminuição da largura da gengiva ceratinizada (tabela 10), é provável que a principal dentre estas variáveis a influenciar o Índice de Sangramento Gengival, seja a largura da mucosa ceratinizada.

Assim, quanto maior a profundidade do sulco gengival, maior a dificuldade de higienização (WAERHAUGH ${ }^{55}$ ) e, portanto, maior o Índice de Sangramento Gengival.

Por sua vez, o fato de se ter encontrado $\mathrm{ISG}=1$ em áreas com pouca quantidade de gengiva ceratinizada vai de encontro ao postulado por LANG; LÖE ${ }^{21}$, que encontraram variação significativa no índice de exudato em indivíduos com boa higiene bucal, porém com quantidades maiores e menores que $2,0 \mathrm{~mm}$ de gengiva ceratinizada.

PASSANEZI $^{3 *}$ implicou essa correlação com o fato de que a permeabilidade da mucosa alveolar pode representar um fator crítico no controle homeostático do sulco gengival quando a união mucogengival atinge ou chega muito próximo do nível da extremidade apical do epitélio juncional. Além disso, a própria falta de imobilização da margem gengival

\footnotetext{
${ }^{3}$ PASSANEZI, E. - Aula de cirurgia mucogengival de curso de pós-graduação em periodontia. FOB/USP, 1996.
} 
associada à inadequacidade da gengiva ceratinizada, pode ser fator de desequilíbrio no comportamento homeostático do sulco gengival.

Dessa forma, a análise conjugada cuidadosa e profunda da correlação entre as variáveis estudadas neste trabalho e o estabelecimento de características bioanatômicas homeostáticas parece fundamental para a preservação do periodontium, seja em abordagens essencialmente preventivas ou terapêuticas. 


\section{CONCLUSÕES}




\section{CONCLUSÕES}

Pelos resultados obtidos à luz da discussão elaborada e considerando-se as características próprias desta pesquisa, foi possível concluir que:

a) a existência de cristas ósseas finas aumenta a propensão de manifestação a sangramento gengival, devido à correlação com tecido gengival fino e com menor largura, alterando a homeostasia periodontal marginal;

b) a distância biológica determinada na região vestibular dos dentes apresenta dimensões muito semelhantes, embora ligeiramente inferior, a proposta por GARGIULO ${ }^{13}$, sendo da ordem de $2,507 \mathrm{~mm}$ para $2,73 \mathrm{~mm}$;

c) por vestibular, as distâncias biológicas nos dentes anteriores são maiores do que nos dentes posteriores;

d) a largura da mucosa ceratinizada é variável de conformidade com o tipo de dente e/ou com o grupo de dente que está sendo analisado, sendo maior nos dentes anteriores do que nos posteriores;

e) a profundidade de sondagem do sulco gengival é tanto maior quanto maior for a espessura da mucosa ceratinizada e a distância da margem gengival à crista óssea;

f) a largura da mucosa ceratinizada correlaciona-se com a espessura, influenciando a formação das distâncias biológicas voltadas contra o dente; 
g) para os incisivos e caninos, existe correlação altamente significativa $(\mathrm{P}<0,001)$ entre a profundidade de sondagem e a distância da margem gengival à crista óssea;

h) há correlação altamente significativa entre a profundidade de sondagem e a distância da margem gengival-crista óssea nos sítios que apresentam a espessura óssea normal;

i) existe correlação estatisticamente significativa entre largura da mucosa ceratinizada e a distância da margem gengival-crista óssea nos sítios que apresentam a espessura óssea normal;

j) nos sítios que apresentam a espessura óssea grossa, quanto maior a profundidade de sondagem, maior a espessura da mucosa ceratinizada (correlação estatisticamente significativa);

k) quando o ISG=0, existem duas correlações altamente significativas estatisticamente, ambas relacionadas com a espessura da mucosa ceratinizada: a profundidade de sondagem e a largura da mucosa ceratinizada; 


\section{REFERÊNCIAS BIBLIOGRÁFICAS}




\section{REFERÊNCIAS BIBLIOGRÁFICAS ${ }^{1}$}

1 AINAMO,A. Influence of age on the loction of the maxillary mucogingival junction. J. Period. Res., v.13, p.189-93, 1978.

2 AINAMO, A.; AINAMO, J. The width of attached gingiva on supraerupted teeth. J. Period. Res., v.13, p.194, 1978.

3 AINAMO, J.; BAY, I. Problems and proposals for recording gingivitis and plaque. Int. dent. J., v.25, p.229-35, 1975.

4 AINAMO, J.; LÖE, H. Anatomical characteristics of gingiva. A clinical and microscopic study of the free and attached gingiva. J. Periodontol., v.37, p.5, 1966.

5 AINAMO, J.; TALARI, A. The increase with age of the width of attached gingiva. J. Period. Res., v.11, p. 182, 1976.

6 ALLEN, E. P. ; MILLER JR., P. Coronal positioning of existing gingiva:short term results in the treatment of shallow marginal tissue recession. J Periodont., v. 60, p. 316-9, June. 1989.

7 ALLISON, E. J. Surgical management of the fractured tooth. Gen. Dent., p.204-209, June 1992.

8 BOWERS, G. M. A study of the width of attached gingiva. J. Periodont., v. 34, p. 205-9, 1963.

9 BOWERS, G. M. et al. Histologic evaluation of new attachment apparatus formation in humans. Part III. J. Periodont., v. 60, p. 683-93, 1989.

10 CARRANZA JUNIOR, F. A. Periodontia clinica. 7. ed. Rio de Janeiro, Guanabara-Koogan, 1992. p. 12-30.

\footnotetext{
${ }^{1}$ Normas recomendadas para uso no âmbito da Universidade de São Paulo, com base no documento "Referências Bibliográficas: exemplos", emanado do Conselho Supervisor do Sistema Integrado de Bibliotecas da USP, em reunião de 20 de setembro de 1990.
} 
11 DE PAOLI, S. ; NEVINS, M. ; CAPPETTA, E. G. The biologic width crown lengthening. In: NEVIS, M. ; MELLONIG, J. T. Periodontal therapy: clinical approaches and evidence of success. São Paulo, Quitessence Books, 1998. v. 1. Cap. 21, p. 319-28.

12 DIFRANCO, C. et al. Identification of langerhans cells in human epithelium. J Periodont., v. 56, p.48-54, Jan. 1985.

13 GARGIULO, A . et al. Dimensions and relations of the dentogingival junction in humans. J Peridont., v. 33, p. 261-7, 1961.

14 GENCO, R. J.; GOLDMAN, H. M.; COHEN, W. Periodontia contemporânea. São Paulo, Santos, 1996. 726p.

15 GOASLING, G. O. et al. Thickness of facial gingiva. J Periodont., v. 48, p. 768-71, 1977.

16 GOLDMAN, H. M. Periodontia. 6. ed. Rio de Janeiro, GuanabaraKoogan, 1983. Cap. 1: p. 1-30

17 HALMON, W.W. et al. Periodontal literature reviews. Chicago:American Academy of Periodontology, 1996. Cap. 9: p. 145197

18 HANCOCK, E., WIRTHLIN, M. The location of the periodontal probe tip in health an disease. J. Periodont., v.52, p.124-9, 1981.

19 HASSEL, T. M. Periodontal tissues structure and function. Periodontology 2000, v. 3, p. 9-38, 1993.

20 JEFFCOAT, M.K. A new probe with automated cemento-enamel junction detection-design. J. clin. Periodont., v.13, p.276-80, 1986.

21 LANG, N.P.; LÖE, H. The relationship between the width of keratinized gingiva and gingival health. J. Periodont., v.43, p.623-7, 1972

22 LINDHE, J. A anatomia do periodonto. In: - Tratado de periodontologia clínica e implantodontia oral. 3.ed. Rio de Janeiro, Guanabara-Koogan, Cap.1, p. 27-9, 1999. 
23 LINDHE, J. Textbook of clinical periodontology. 15.ed . Philadelphia, Saunders. 1983. p. 22.

24 LINDHE, J. Textbook of clinical periodontology. 2.ed. Copenhagen, Munksgaard, 1989. p. 22-23.

25 LISTGARTEN, M. A . et al. Incidence of periodontitis recurrence in treated patients with and without cultivable actinobacillus actinomycetemcomitans, prevotella intermedia, and porphyromonas gingivalis: a prospective study. J Periodont., v. 62, n. 6, p. 377-86, June 1991.

26 LÖE, H. et al. A gengiva:estrutura e função. In: GENCO, R. J.; GOLDMAN, H. M.; COHEN, W. Periodontia contemporânea. São Paulo, Santos, 1996. Cap. 1, p. 3-32.

27 LÖE, H. The Gingival Index, the Plaque Índex and the Retention Índex system. J. Periodont., v.38, p.610-6, 1967.

28 LÖE, H.; LISTGARTEN, M.A.; TERRANOVA, V.P. The gingiva: structure and function. In: GENCO, R.J.; GOLDMAN, H. M.; COHEN, D.W. Contemporary Periodontics.. St. Louis, Mosby, 1990. p.3-32.

29 LUNDERGAN, W.; HUGHES JUNIOR, W. Crown lengthening: a surgical flap approach. Compendium, v.17, n. 9, p. 833-44, 1996.

30 MAGNUSSON, I. et al. A long junctional epithelium : a locus minoris resistentiae in plaque infection? J. clin. Periodont., v. 10, p.33-340, 1983.

31 MAGNUSSON, I., LISTGARTEN, M.A. Normal development, structure, physiology and repair of gingival epithelium. Oral Sciences Reviews, v.1, p.3-67, 1980.

32 MAYNARD, J. G. ; WILSON, R. D. K. Physiologic dimensions of the periodontium significant to the restorative dentist. J. Periodont., v. v.50, n.4, p.170-4, Apr. 1979. 
33 MUHLEMANN, H.R.; SON,S. Gingival sulcus bleeding-aleading syntom in initial gingivitis. Helv. Odont. Acta. v.15, p.107-13, 1971.

34 NEVINS, M. ; CAPPETTA, E. G. Periodontal therapy. In: WORD WORKSHOP IN CLINICAL PERIODONTICS, New Jersey, 1989. Proceeedings...New Jersey, American Academy of Periodontology, 1989.

35 NEVIS, M. ; MELLONIG, J. T. Periodontal therapy: clinical approaches and evidence of success. São Paulo, Quintessence Books, 1998.

36 NYMAN, S. ; LINDHE, J.; KARRING, T. Tratado de periodontologia clínica. Rio de Janeiro, Interamericana, 1985. p. 339-54.

37 OSBORN, J. Comparison of measurement variability using a standard and contant force periodontal probe. J. Periodont., v.61, p.497-503, 1990.

38 PAGE, R. C. Periodontal therapy:prospects for the future. J Periodont., v.64, p.744-53, Aug. 1993.

39 PASSANEZI, E.; JANSON, W.A.; CAMPOS JÚNIOR., A.; SANT’ANA, A. C.P. Planejamento periodontal tendo em vista tratamentos estético e protético. In: GONÇALVES, E.A.N.; FELLER, C. Atualização na clínica odontológica. São Paulo, Artes Médicas, 1998. Cap.20, p.481540.

40 RAMFJORD, S. P.; ASH JUNIOR, M. Periodontologia e periodontia: teoria e prática moderna. São Paulo, Ed. Santos, 1991.

41 RATEISCHAK, K. H.; WOLF, E. M. Atlas de periodoncia. 2.ed. Barcelona, Salvat, 1991.

42 RATEITSCHAK, K. H.; WOLF, K.; HASSELL, T. M. Color atlas of dental medicine: periodontology. 2. ed. New York, Thieme Medical Publishers, 1989.

43 SCHLUGER, S. et al . Periodontal diseases. Philadelphia, Lea \& Febiger, 1990. 
44 SCHROEDER, H. F. Fenômenos básicos do periodonto normal. In: SCHLUGER, S. et al. Periodontia. Rio de Janeiro, Interamericana, 1991. p. 5-53.

45 SELVIG, K.A. The fine structure of human cementum. Acta Odont. Scand., v.23, p.423-41, 1965.

46 SILNESS, J.; LÖE, H. Periodontal disease in pregnancy. II. Correlation between oral hygiene and periodontal condition. Acta Odont. Scand., v.22, p.112-35, 1964.

47 SIMS T, M.; CARRANZA JÚNIOR. F. A.Anatomia do Periodonto In: CARRANZA, F. A.; NEWMAN, M. G. Peridontia clínica. 8. ed. Rio de Janeiro, Guanabara-Koogan, 1997. p. 654-61

48 SPRAY, J. et al. Microscopic determination of the position of periodontal probes.. J. Periodont., v.49, p.148-52, 1978.

49 TARNOW,D.P.; MAGNER,A.W.; FLECTCHER,P. The effect of the distance from the contact poit to the crest of bone on the presence or absence of the interproximal dental papilla. J. Periodont., v.63, n.12, p.995-6, Dec. 1992.

50 TARNOW,D.P.; STHAL,S.S.; MAGNER,S.;ZAMZOK,J. Human gingival attachment responses to subgingival crowns placement. Marginal remodelling. J.clin.Periodont., v.13, n.6, p.563-9, July 1986.

51 TEN CATE, A.; DEPORTER, D. A.; FREEMAN, E. The role of fibroblasts in the remodeling of periodontal ligament during physiologic tooth movement. Amer. J. Orthod., v.69, p. 155, 1976.

52 TEN CATE, A. R. Histologia bucal: desenvolvimento, estrutura e função. Rio de Janeiro, Guanabara-Koogan, 1985. p. 209-34

53 VELDEN, V.U., JANSEN, J. Introduction of a new periodontal probe: the pressure probe. J. clin. Periodont., v.5, p.188-97, 1978.

54 WAAL, H.; CASTELLUCCI, G. The importance of restorative margin placement to the biologic width and periodontal health. Part I. Int. J. Periodont. Rest. Dent., v.13, n.6, p.461-71, Nov./Dec. 1993. 
55 WAERHAUG, J. Healing of the dento-epithelial junction following subgingival plaque control. II. As observed on extracted teeth. J. Periodont., v.49, n.3, p. 119-34, Mar. 1978.

56 WILSON, T. G. ; KORMAN, K. S. Fundamental of periodontics. Rio de Janeiro, Quintessence Books, 1996.

57 YUKNA, R. Longitudinal evalutation of the excisional new attachment procedure in humans. J Periodont., v. 49, n.3, p. 142-4, Mar.1978. 
ABSTRACT 


\section{ABSTRACT \\ VALUATION AND ANALYSES OF BIOLOGIC WIDTH OF PERIODONTICS ACCORDING TO NEW METHODOLOGY}

The multiple causes for periodontal disease makes very difficult the diagnosis, prognostic and the treatment planning. With the development of material biotechnology, we believe that the solution to the sequelae from periodontal disease is close to have a favourable outcome both to the clinician and to the patient. The methods to control periodontal disease are still limited and the appearance of high sensitive equipment is necessary to make feasible the previous detection of attachment loss. The parameters of the periodontal spaces advocated by Gargiulo and cols determine the prosthetic, esthetic, and surgical current protocols as well as the maintenance of the treated patients in order to garantee the homeostasis of both protection and supporting periodontium. Three hundred ninety-six measures in adjacent teeth of 32 patients were made by only one clinician, these patients would undergo osseointegrated implants, and they were not distinguished by race or gender, the age group was from 15 to 68 years old, 13 males and 19 females, 4 smokers and 28 non-smokers. The objective of this investigation was to analyse the effectiveness of a sonar to evaluate the soft tissues thickness - SDM - (non-invasive technique), making a relationship with the known parameters of the periodontal spaces such as manual probing depth, the alveolar bone thickness, the distance between the gingival margin to the bone crest and the dichotomic bleeding following probing; trying to determine a more accurated relationship among the parameters of the periodontal spaces already known. According to the obtained results, we concluded that a thin bone crest support a tissue with a 
more fragile collagen and with worse homeostasis, the distance between the gingival margin to the bone crest showed an average of $2,507 \mathrm{~mm}$, slightly smaller than the one found by Gargiulo and cols, which was $2,73 \mathrm{~mm}$; the periodontal spaces in the anterior teeth are bigger than in the posterior ones; the keratinized mucosa width is bigger in incisives and canines than in premolars and molars. There are strong relationships between probing depth and keratinized mucosa thickness; probing depth and distance from gingival margin to bone crest, width and thickness of keratinized mucosa; probing depth and the distance from the gingival margin to the bone crest for incisives and canines. Where there is normal bone thickness, there is a strong relashionship between probing depth and the distance from the gingival margin to the bone crest, as well as between the keratinized mucosa width and the distance from the gingival margin to the bone crest. Where the bone thickness is dense, the bigger is the probing depth, the bigger is the keratinized mucosa thickness. When the gingival index is 0 , the keratinized mucosa thickness shows a strong relationship with the probing depth and with the keratinized width. 